\title{
Advanced Development of the Nested Fiber Filter
}

\section{Topical Report}

\author{
R. D. Litt \\ R. C. Glover \\ J. K. Raghavan
}

May 1993

Work Performed Under Contract No.: DE-AC21-89MC26233

For

U.S. Department of Energy

Office of Fossil Energy

Morgantown Energy Technology Center

Morgantown, West Virginia

By

Battelle

Columbus, Ohio 


\section{DISCLAIMER}

This report was prepared as an account of work sponsored by an agency of the United States Government. Neither the United States Government nor any agency thereof, nor any of their employees, makes any warranty, express or implied, or assumes any legal liability or responsibility for the accuracy, completeness, or usefulness of any information, apparatus, product, or process disclosed, or represents that its use would not infringe privately owned rights. Reference herein to any specific commercial product, process, or service by trade name, trademark, manufacturer, or otherwise does not necessarily constitute or imply its endorsement, recommendation, or favoring by the United States Government or any agency thereof. The views and opinions of authors expressed herein do not necessarily state or reflect those of the United States Government or any agency thereof.

This report has been reproduced directly from the best available copy.

Available to DOE and DOE contractors from the Office of Scientific and Technical Information, P.O. Box 62, Oak Ridge, TN 37831; prices available at (615) 576-8401.

Available to the public from the National Technical Information Service, U.S. Department of Commerce, 5285 Port Royal Rd., Springfield, VA 22161; phone orders accepted at (703) 487-4650. 


\section{DISCLAIMER}

Portions of this document may be illegible in electronic image products. Images are produced from the best available original document. 


\title{
Advanced Development of the Nested Fiber Filter
}

\author{
Topical Report
}

\author{
R. D. Litt \\ R. C. Glover
}

J. K. Raghavan

Work Performed Under Contract No.: DE-AC21-89MC26233

\author{
For \\ U.S. Department of Energy \\ Office of Fossil Energy \\ Morgantown Energy Technology Center \\ P.O. Box 880 \\ Morgantown, West Virginia 26507-0880 \\ By \\ Battelle \\ 505 King Avenue \\ Columbus, Ohio 43201-2693
}

May 1993 
Battelle and DOE have been developing the Nested Fiber Filter for high-temperature, highpressure particulate control as applied to advanced coal-fired power systems. The current program represents a focused effort to develop cleaning techniques for the NFF at pilot plant scale. The filter consists of a 10-inch deep nest of stainless steel fibers collecting particles as dendrites on individual fibers. A gradient of particles builds up within the nest with the greatest concentration at the bottom.

Tests with a 6- $\mathrm{ft}^{2}$ Nested Fiber Filter (NFF) have demonstrated greater than 99 percent particulate capture over a limited number of operating hours. The NFF outlet particulate loading was measured at $22 \mathrm{ppm}$ and $44 \mathrm{ppm}$ during two successful tests at maximum operating conditions in the test facility. The goal is to reduce particulate emissions to less than $30 \mathrm{ppm}$ which is equivalent to EPA's New Source Performance Standard of 0.03 pound particulate per million Btu. Problems with gas and particulate bypassing were overcome by using compressed insulation at the walls and keeping the fibers under a compressive load. Additional tests are recommended to demonstrate sustained reliable operation of the NFF and evaluation of alternative methods to improve performance by overcoming the bypassing problem.

Design, development, and testing a 6 - $\mathrm{ft}^{2}$ module $\left(1.5^{\prime} \times 4^{\prime}\right.$ cross section) proceeded in three sequential stages. The NFF test module was integrated with a fluidized bed combustor to provide a realistic particulate laden gas to the NFF. Initial problems with gas and particulate bypassing plus ineffective cleaning by acoustic drivers led to a series of tests on a $1.5 \mathrm{ft}^{2}$ section $\left(1^{\prime} \times 1.5^{\prime}\right)$ of the NFF. These interim tests demonstrated excellent particulate capture ( $>99$ percent) with compressed Fiberfrax ${ }^{\circledR}$ insulation lining the side walls to prevent voids and the bypassing which had occurred. The fiber bed was slightly compressed to further prevent voids forming at the side walls during the vibration cleaning cycle. A mechanical vibrator was coupled with the pulse combustor to effectively clean/regenerate the NFF over a limited number of cycles.

Testing resumed with the $6-\mathrm{ft}^{2}$ test module and the above modifications to overcome the gas and particulate bypassing problem. Two tests totalling 15 hours of operation and 14 repetitive cycles are summarized here and demonstrated the NFF performance.

Test

Face Velocity ( $\mathrm{ft} / \mathrm{min})$

Temperature $\left({ }^{\circ} \mathrm{F}\right)$

NFF dp prior to cleaning ("water)

NFF dp after cleaning ("water)

Cleaning Duration (min)

Average Time Between Cleaning (min)

Number of Cycles

Inlet Particulate Loading (average, ppm)

Outlet Particulate Loading (ppm)

Particulate Collection Efficiency (\%)

\section{1-1/93}

200

1170

10

4

20

30

6

2424

44

99.2
2-1/93

195

1180

11

4

15

30

8

2424

22

99.1 
These data and the experience gained in developing the NFF at the $6-\mathrm{ft}^{2}$ show this to be a significant alternative to other high-temperature, high-pressure particulate filters being developed by DOE and others. The preliminary engineering and economic evaluation showed the NFF to be costcompetitive with the ceramic cross-flow filter and the granular bed filter. Capital cost for a NFF on a $330 \mathrm{MW}$ PFBC is estimated to be $\$ 42.9$ million or $\$ 130 / \mathrm{kW}$. The total plant cost for a PFBC system including the NFF is estimated to be $\$ 1274 / \mathrm{kW}$. This compares to $\$ 1261 / \mathrm{kW}$ for a $P F B C$ plus ceramic cross-flow filter or $\$ 1351 / \mathrm{kW}$ for a PFBC plus granular bed filter.

Additional research and development of the NFF is recommended to improve the reliability and demonstrate extended operation with high particulate efficiency. Six to 12 months of additional testing is recommended prior to scale-up for a prototype or demonstration-scale application. 


\section{Table of Contents}

$\underline{\text { Page }}$

Summary $\ldots \ldots \ldots \ldots \ldots \ldots \ldots \ldots \ldots \ldots \ldots \ldots \ldots \ldots \ldots \ldots \ldots$

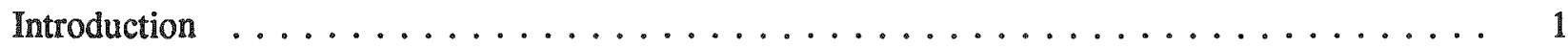

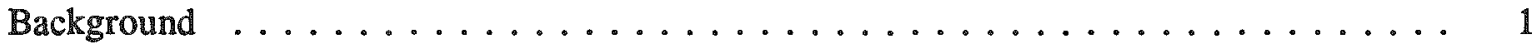

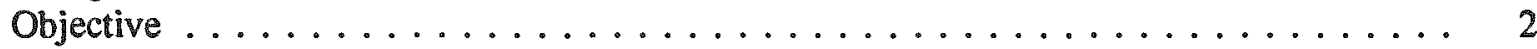

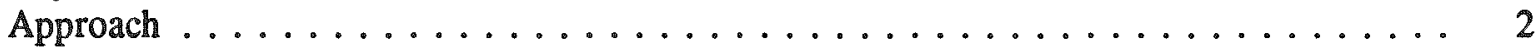

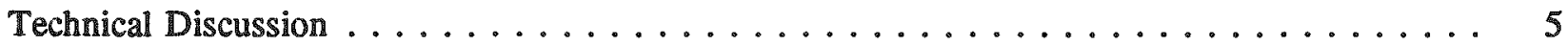

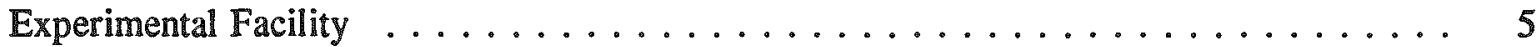

Aerovalved Pulse Combustor $\ldots \ldots \ldots \ldots \ldots \ldots \ldots \ldots$

Sonic Horn . . . . . . . . . . . . . . . . . . . . . . . 9

METC Pulse Combustor . . . . . . . . . . . . . . . . . . . 11

Fluidized Bed Combustor . . . . . . . . . . . . . . . . . . . . 11

Test Results . . . . . . . . . . . . . . . . . . . . . . . . 15

Acoustic Cleaning/Regeneration Performance .............. 15

Filter Performance . . . . . . . . . . . . . . . . . . . . . 18

Reduced Cross-Sectional Area (Stage 2 Testing) . . . . . . . . . . . . . 21

$6-\mathrm{ft}^{2}$ NFF Tests (Stage 3 Testing) . . . . . . . . . . . . . . . 26

Testing of Various Acoustical Sources for Cleaning Nested Fiber Filter . . . . . . 30

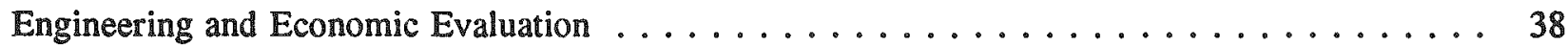

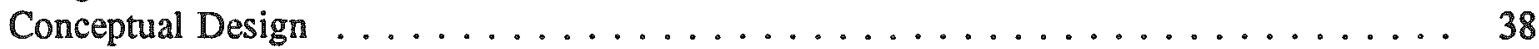

Conclusions and Recommendations $\ldots \ldots \ldots \ldots \ldots \ldots \ldots \ldots \ldots \ldots$

Recommendations ........................... 46

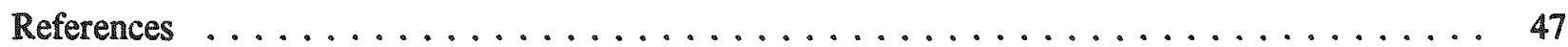

Appendix A Test Data 


\section{List of Tables}

Page

Table 1. Acoustic Driver Performance $\ldots \ldots \ldots \ldots \ldots \ldots \ldots \ldots \ldots$

Table 2. FBC Operating Conditions ........................... 16

Table 3. Test Summary with Acoustic Cleaning (Stage 1) . . . . . . . . . . . . . . . 17

Table 4. NFF Inlet Particle Size Distribution . . . . . . . . . . . . . . . 21

Table 5. NFF Performance Results for Tests 12-1 and 12-2: $1^{\prime} \times 1.5^{\prime} \times 8$ " Modified Bed . ... 24

Table 6. Test Summary with Mechanical Vibration Cleaning . . . . . . . . . . . . . . . 27

Table 7. Capital Cost Estimate ........................... 42

\section{List of Figures}

Figure 1. Fiber Filtration Concept $\ldots \ldots \ldots \ldots \ldots \ldots \ldots \ldots \ldots \ldots \ldots \ldots$

Figure 2. Nested Fiber Filter Test Module $\ldots \ldots \ldots \ldots \ldots \ldots \ldots \ldots$

Figure 3. NFF Baskets ............................ 7

Figure 4. Pulse Combustor Modifications Allowed for Compressed Air to be Introduced in High-Pressure, High-Temperature Applications ................ 8

Figure 5. Prototype Sonic Horn Mounted on Test Bench for NFF Cleaning Using High Sound Pressure Levels ... . . . . . . . . . . . . . . . . . . . . 10

Figure 6. Traversining Horizontally Rather than Length . . . . . . . . . . . . 12

Figure 7. METC Pulse Combustor $\ldots \ldots \ldots \ldots \ldots \ldots \ldots \ldots \ldots \ldots \ldots$

Figure 8. 24-Inch Fluidized Bed Facility . . . . . . . . . . . . . . . . . 14

Figure 9. Filter $\Delta \mathrm{P}$ versus Time . . . . . . . . . . . . . . . . . . . . 19

Figure 10. Schematic Representation of the Modified Basket Used in Tests 12-1 and 12-2 . . . 23

Figure 11. NFF Tests $\left(12-1\right.$ to 12-2):1' $1.5^{\prime} \times 8$ " Bed . . . . . . . . . . . . . 25

Figure 12. $\mathrm{dp}$ Profiles During Test $1-1$, with $4^{\prime} \times 1.5^{\prime} \times 12^{\prime \prime}$ NFF Basket . . . . . . . . . 28

Figure 13. Frequency Response Plot for Measured SPL of Acoustic Horn With and Without Baffles. Recorded at Room Temperature Conditions . . . . . . . . . . . . . . 31

Figure 14. Frequency Response Plot for Measured SPL of Acoustic Horn Mounted on Top Chamber of NFF. . . . . . . . . . . . . . . . . . . . 33

Figure 15. Frequency Response Plot for Measured SPL of Small Pulse Combustor Mounted on Top Chamber of NFF . . . . . . . . . . . . . . . . . . . . . 34

Figure 16. Frequency Response Plot for Measured SPL of Backfiring Large Pulse Combustor Mounted on Lower Chamber of NFF . . . . . . . . . . . . . . . . . 35

Figure 17. Frequency Response Plot for Measured SPL of Large Pulse Combustor Running Smoothly, Mounted on Lower Chamber of NFF . . . . . . . . . . . . . 36

Figure 18. PFBC Steam Cooled System . . . . . . . . . . . . . . . . . . . . . 39

Figure 19. Battelle NFF Horizontal Configuration $\ldots \ldots \ldots \ldots \ldots \ldots$ 


\section{ADVANCED DEVELOPMENT OF THE NESTED FIBER FILTER}

\section{TOPICAL REPORT}

to

\section{U.S. DEPARTMENT OF ENERGY \\ Morgantown Energy Technology Center}

by

R. D. Litt, R. C. Glover, and J. K. Raghavan

from

BATTELLE

Industrial and Commercial Technology Division

May 1993

\section{Introduction}

This report describes the continuing development of the Nested Fiber Filter (NFF) for the U.S. Department of Energy (DOE) under contract number DE-AC21-89MC26233 for the period extending from August 1989 to March 1993. This study follows a previous investigation of the NFF for High-Temperature, High-Pressure Particulate Removal, DOE Contract No. DE-AC21$86 \mathrm{MC} 23251$.

\section{Background}

Battelle's work on the Nested Fiber Filter began in 1983 with internally-funded benchscale tests to prove the concept feasibility. The NFF concept is based on the following observed effect: randomly oriented metallic fibers of appropriate length-to-diameter ratio tend to form an interlocking nest with high voidage, and, therefore, low gas pressure drop at face velocities of 200 feet per minute (fpm). The particulate collection efficiency and pressure drop compares well with that for typical bag filters with face velocities of 2 to $4 \mathrm{fpm}$. The resulting benefit of the high throughput of the NFF is a significant reduction in the required equipment volume and the associated capital cost for particulate filters in many applications. Technical feasibility of the NFF has been proven in 
bench-scale and continuous mini-plant tests. Some promising applications of the NFF include pressurized fluidized bed combustion, integrated coal gasification combined cycle, and coal-fired gas turbines.

The NFF concept, shown in Figure 1, has the particulate laden gas pass upward through a 10-inch deep nest of stainless steel fibers. Particulate collection is greatest at the bottom of the nest as dendrites are formed on individual fibers. Dirty gas flow is stopped during the cleaning/ regeneration cycle and an acoustic or mechanical vibrator is operated to remove the particulate from the fibers. The collected particles are removed by gravity and then the NFF is returned to filtration service completing the cycle.

In 1986, Battelle entered into a contract with DOE to begin development of the NFF for high-temperature, high-pressure particulate control. The current program represents a focused effort to evaluate cleaning techniques at pilot plant scale for the NFF. The practical cleaning technique needs to be demonstrated at high temperature and integrated with the high-efficiency filter performance expected of the NFF.

\section{Objective}

The overall objective of this program is to advance the development of the Nested Fiber Filter. Initial project activities evaluated three cleaning techniques (mechanical impact, acoustic vibration, and pulse jet blowback) to identify the most practical and effective method for the NFF concept. NFF testing at the pilot plant scale was integrated with an existing fluidized bed combustor. The engineering evaluation was for application to a Pressurized Fluidized Bed Combustor.

This Topical Report covers the integrated filtration and cleaning/regeneration testing of a 6- $\mathrm{ft}^{2}$ test module operating on the particulate-laden combustion gas from a fluidized bed combustor.

\section{Approach}

This phase of the program was executed in three sequential stages. In the first stage, a 6- $\mathrm{ft}^{2}$ NFF test module was designed and constructed to operate in an integrated manner based on prior test results. ${ }^{\text {(1) }}$ Acoustic cleaning devices were installed at multiple locations in the module to achieve fiber cleaning at this scale with representative flyash and combustion gas. Testing during this stage 


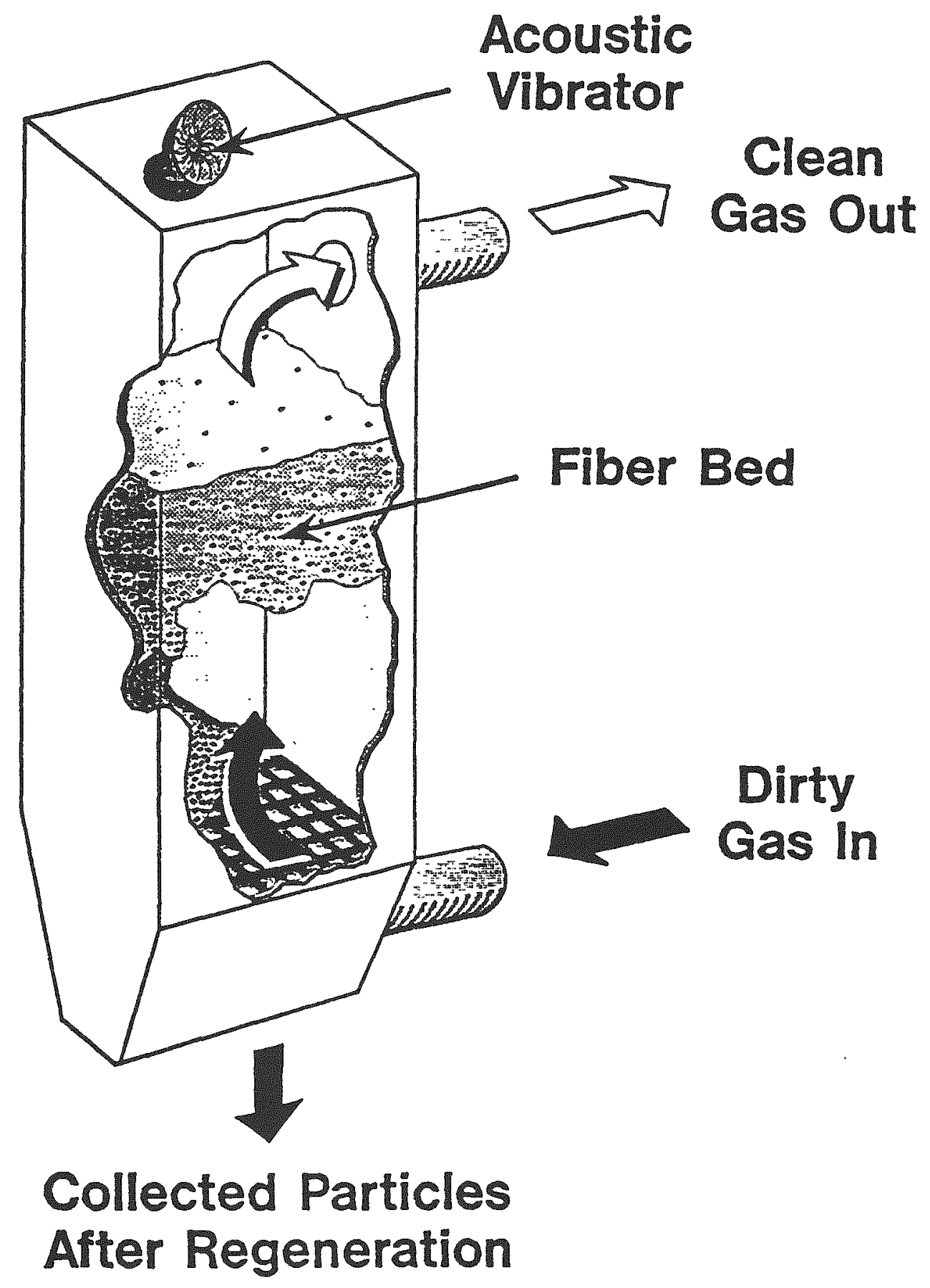

Figure 1. Fiber Filtration Concept 
revealed problems with gas and particulate bypassing the NFF, and in inadequate cleaning due to the low acoustic energy intensity.

Following this investigation, a second stage of testing was conducted to address these problems. For this purpose, the module was redesigned for a smaller cross section $\left(1.5 \mathrm{ft}^{2}\right)$. Changes to the vertical walls of the filter were incorporated to eliminate gas and particulate bypassing. In addition, a high intensity pneumatically driven mechanical impact vibrator was installed to aid acoustic cleaning.

In the third stage, following the successful results of second stage effort, testing was resumed with a 6 - $\mathrm{ft}^{2}$ cross-section filter module. Similar modifications were made to the 6 - $\mathrm{ft}^{2}$ module to prevent gas and particulate bypassing. Limited number of tests conducted during the third stage clearly identified the areas that need further research.

In all the three stages of this test program, cleaning/regeneration of the NFF was the primary emphasis of the testing. Establishing the performance of the acoustic devices (sound pressure level, frequency and location) was important as well as the cycle time between cleaning the NFF. Operating parameters for the FBC and NFF were continuously monitored with a data acquisition system to characterize the inlet and outlet gas stream. Particulate capture efficiency was calculated based on inlet and outlet particulate loadings.

A conceptual application of the NFF to a Pressurized Fluidized Bed Combustion provides an engineering and economic evaluation of the technology at this stage of development. 


\section{Technical Discussion}

This section presents the progression of experimental development and evaluation consistent with the experience and results that were gained. Interim results and program milestones were used to adjust the experimental plan in a problem-solving manner consistent with the overall objective of advancing the NFF technology. The experimental facilities are described and then the initial test results. Interim equipment modifications are described with the corresponding results. The final series of tests are described with results that reflect the current state of development and problems that remain to be solved.

\section{Experimental Facility}

The NFF test module, shown in Figure 2, was designed with a rectangular cross-section $\left(18^{\prime \prime} \times 48^{\prime \prime}\right)$ to evaluate the effectiveness of the acoustic drivers at various locations. The test module was constructed of stainless steel 310 with external insulation. Stainless steel 310 fibers are supported in a removable basket which fits inside the test module. The basket had a perforated metal grid, as shown in Figure 3, for support and gas distribution.

The pulse combustor and the sonic horn were both tested with the 6- $\mathrm{ft}^{2}$ test module. The pulse combustor mounts on either the top, or lower-side positions to test location, cleaning effectiveness, and scaling in the 4-ft dimension. Distance from the pulse combustor to the NFF fibers can be varied by adding various pipe lengths to the mounting flange or by varying the basket location within the NFF test module. The sonic horn can be mounted at the same locations. This device requires continuous purge air to keep the diaphragm below $600 \mathrm{~F}$.

\section{Aerovalved Pulse Combustor}

An existing aerovalved pulse combustor was modified, as shown in Figure 4, for use with the NFF. This device was initially mounted on top of the test module firing vertically down onto the top fiber surface. The natural gas-fired pulse combustor displaced some fibers from the nest creating a 3-inch deep crater on the top surface. This problem and the attenuation (loss) of sound pressure level above and below the fiber basket led to the decision to move the pulse combustor to the 


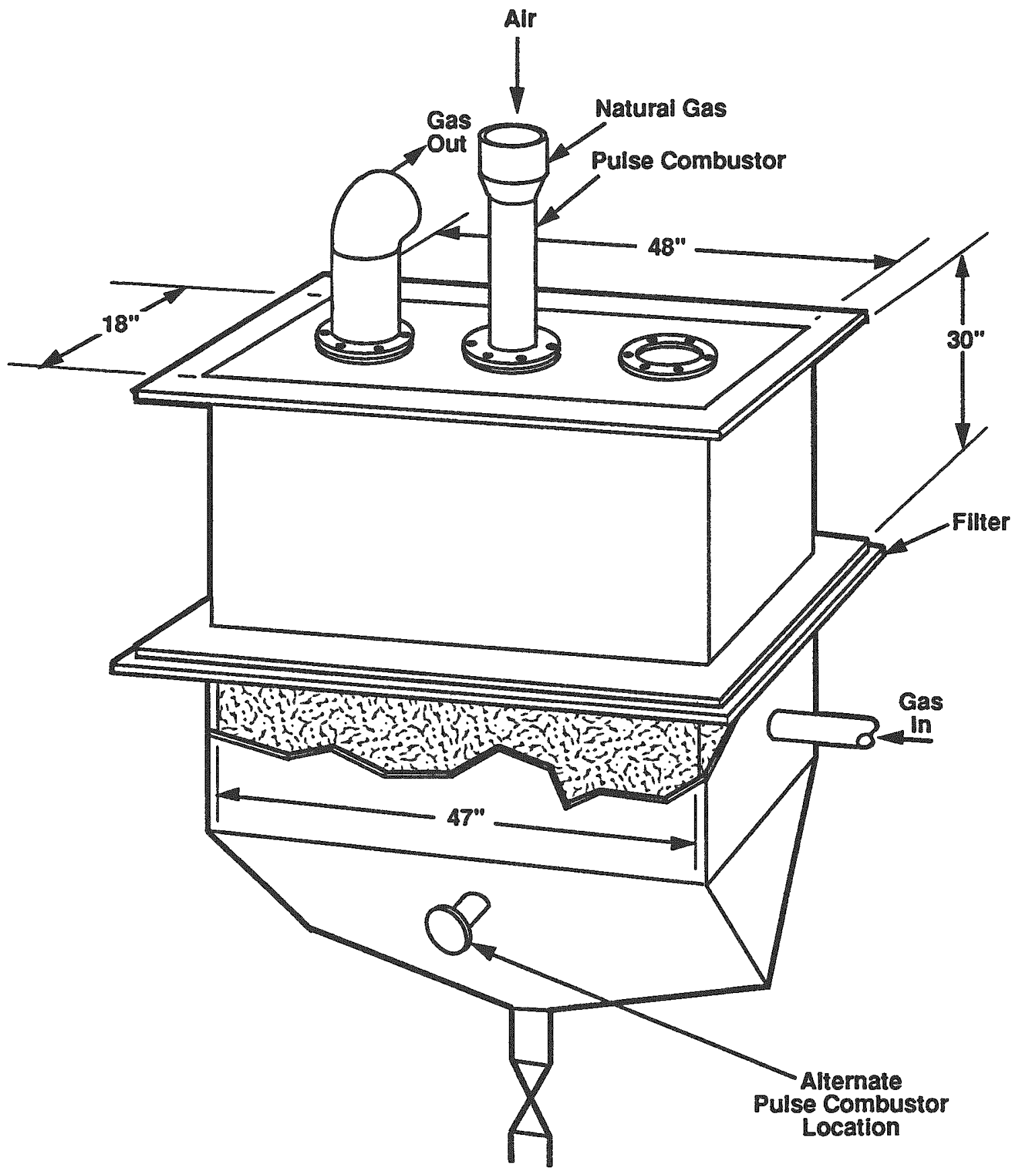

" not to scale

Collection Drum

Figure 2. Nested Fiber Filter Test Module 


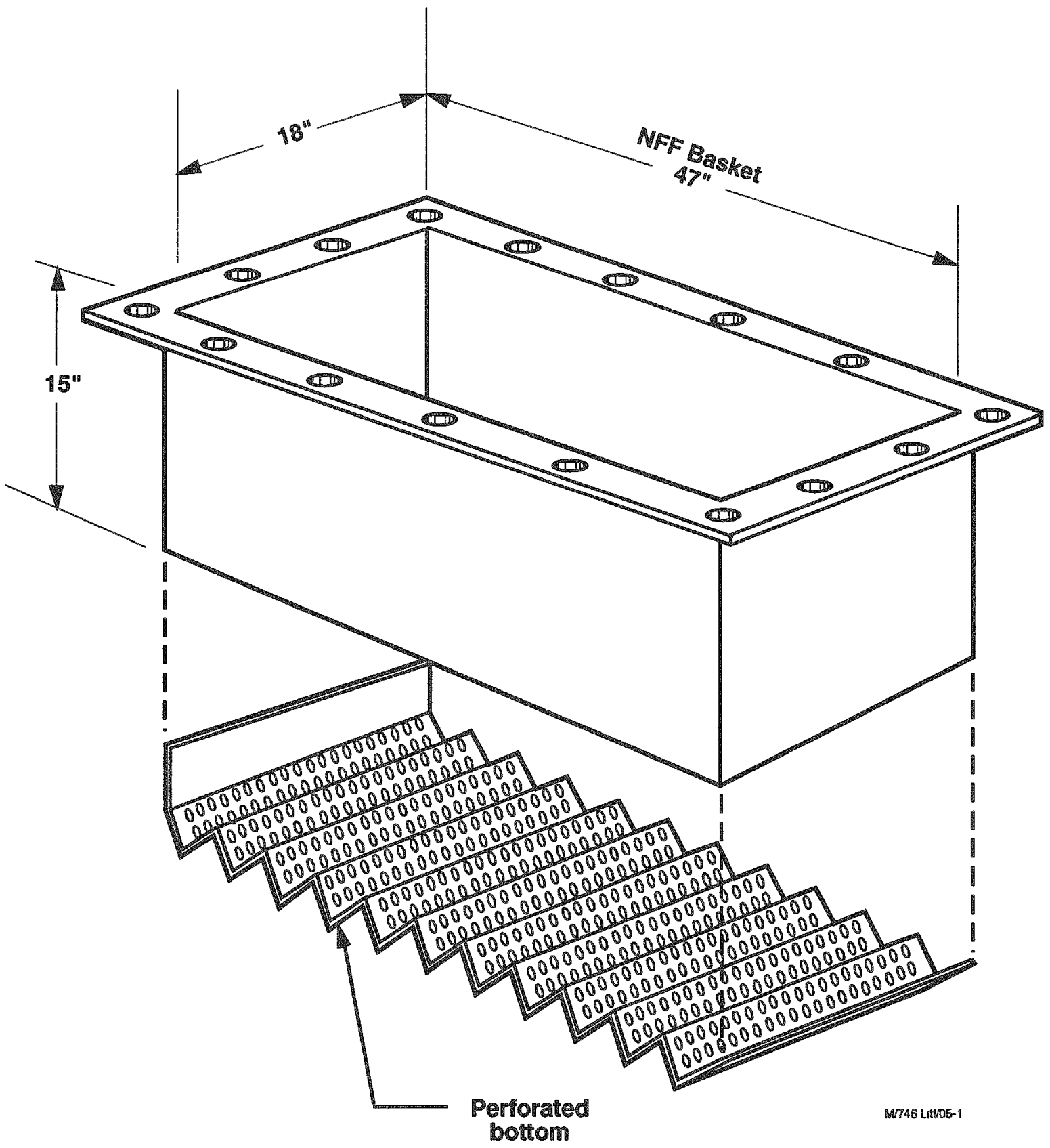

Figure 3. NFF Baskets 


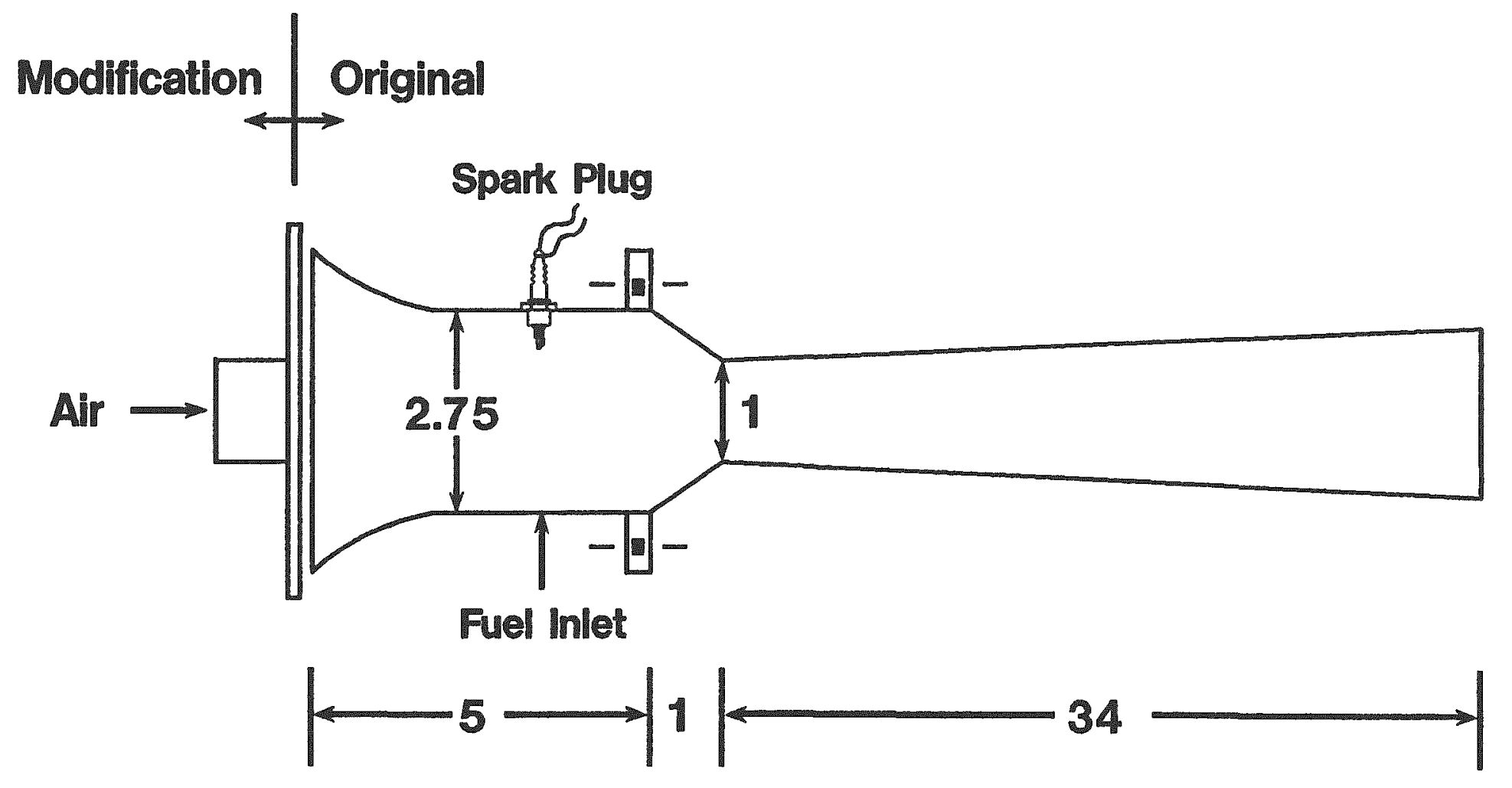

Figure 4. Pulse Combustor Modifications Allowed for Compressed Air to be Introduced to High-Pressure, High-Temperature Applications 
lower-side location. This pulse combustor generated a sound pressure level (SPL) of $140 \mathrm{db}$ at 130 hz in the bench-scale tests but was only producing $127 \mathrm{db}$ above the bed and $115 \mathrm{db}$ below the bed. Table 1 summarizes the acoustic performance of the aerovalved pulse combustor and other acoustic devices.

Table 1. Acoustic Driver Performance

\begin{tabular}{|c|c|c|c|c|c|}
\hline \multirow[b]{2}{*}{ Device } & \multirow{2}{*}{$\begin{array}{l}\text { Mounting } \\
\text { Location }\end{array}$} & \multicolumn{2}{|c|}{ Sound Pressure Level (db) } & \multirow{2}{*}{$\begin{array}{l}\text { Frequency } \\
\text { (hz) }\end{array}$} & \multirow[b]{2}{*}{ Effectiveness } \\
\hline & & Above bed & Below bed & & \\
\hline \multirow{3}{*}{$\begin{array}{l}\text { Aerovalved Pulse } \\
\text { Combustor }\end{array}$} & Top & 127 & 115 & 142 & Ineffective \\
\hline & Lower side & 111 & 131 & 143 & Ineffective \\
\hline & $\begin{array}{c}\text { Lower side } \\
\text { (Propane fuel) }\end{array}$ & 115 & 133 & 152 & Ineffective \\
\hline \multirow{2}{*}{$\begin{array}{l}\text { METC Pulse } \\
\text { Combustor }\end{array}$} & Lower side & 125 & 133 & 105 & Marginal \\
\hline & $\begin{array}{l}\text { Lower side } \\
\text { (Propane fuel) }\end{array}$ & 122 & 130 & 105 & Ineffective \\
\hline Sonic Horn & Top & 139 & 132 & 165 & Ineffective \\
\hline
\end{tabular}

\section{Sonic Horn}

An air-powered sonic horn was tested to evaluate this commercially available device as the acoustic driver for cleaning the NFF. A high-temperature prototype model was purchased from BHA Consultants. This horn is typical of devices used in baghouse cleaning or sootblowing applications. The horn has a 4-inch diameter which joined an expansion tube, as shown in Figure 5, for connection to the NFF. It is capable of generating $160 \mathrm{db}$ in a 4-inch diameter plane wave tube, which produced effective cleaning. However, because of the large volume of the NFF test module, the SPL output of the acoustic horn driver was about $139 \mathrm{db}$. The increase in attenuation due to the large fiber bed also contributed to the lower SPL in the NFF module. The SPL produced by all of the acoustic sources were not high enough to produce effective cleaning of the fiber bed in the module. Some hope was given to increasing the acoustic energy in the module through improved acoustic coupling or eliminating possible standing wave nodes. Dr. Gerhard Reethoff (a consultant) 


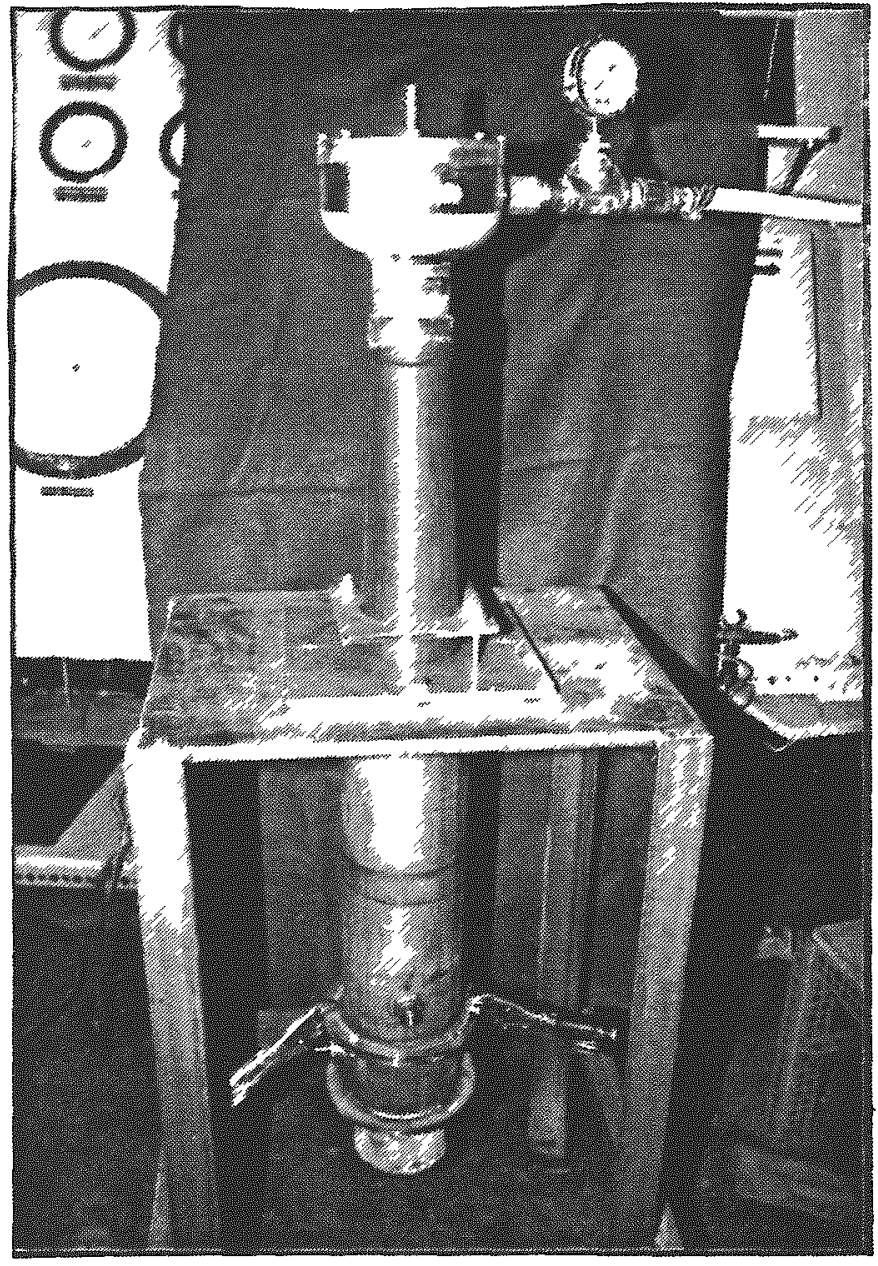

Figure 5. Prototype Sonic Horn Mounted to Test Bench for NFF Cleaning Using High Sound 
recommended several tests to determine the acoustic profile in the chamber to investigate this possibility.

The results of the tests are shown graphically in Figure 6. The combustion acoustic probe, measuring sound pressure fluctuations in the module was placed at various positions traversing the length and height of the filter above the bed with the acoustic horn operating.

The top graph shows that the SPL near the filter bed is similar to that produced near the horn outlet, indicating that there is no standing wave nodes at the filter bed. The bottom graph shows that the SPL and pressure level at the side wall is slightly higher than the level directly over the center of the bed. This is expected due to the highly reflective surfaces at the walls and the absorptive surface of the filter bed. The difference in levels did not indicate a severe standing wave condition, except possibly at $1000 \mathrm{~Hz}$. This could be reduced by creating a narrower module with a length $1 / 2$ to $1 / 3$ of the first module. This would also increase the sound pressure level due to the decrease in cross-sectional area. Otherwise, no significant improvement could be found based on these test results. An increase in acoustic energy at the filter bed, similar to the levels created in the plane wave test model, was needed to produce effective acoustic cleaning.

\section{METC Pulse Combustor}

METC had developed a pulse combustor for other applications that offered potentially higher energy output and SPL. ${ }^{(1)}$ Battelle duplicated this pulse combustor, shown in Figure 7, for testing with the NFF. The METC pulse combustor generated $133 \mathrm{db}$ acoustic output when installed on the lower side of the test module. This was marginally effective in cleaning the NFF as the "clean" filter $\Delta \mathbb{P}$ increased with each successive cycle. Operating this pulse combustor in an unstable (backfiring) manner could produce a maximum peak SPL of $165 \mathrm{db}$ for a very short time. Cleaning effectiveness was still marginal with the unstable operation and this was stopped because it caused mechanical damage to the supports holding the filter basket in place.

\section{Fluidized Bed Combustor}

An existing fluidized bed combustor (FBC, shown in Figure 8) generated representative hot combustion gas for the NFF. The FBC burns approximately $100 \mathrm{lb} / \mathrm{hr}$ coal as a complete system with limestone sorbent feed for $\mathrm{SO}_{2}$ control, a primary cyclone upstream of the NFF and a baghouse 


\section{NFF ACOUSTIC INSPECTION}

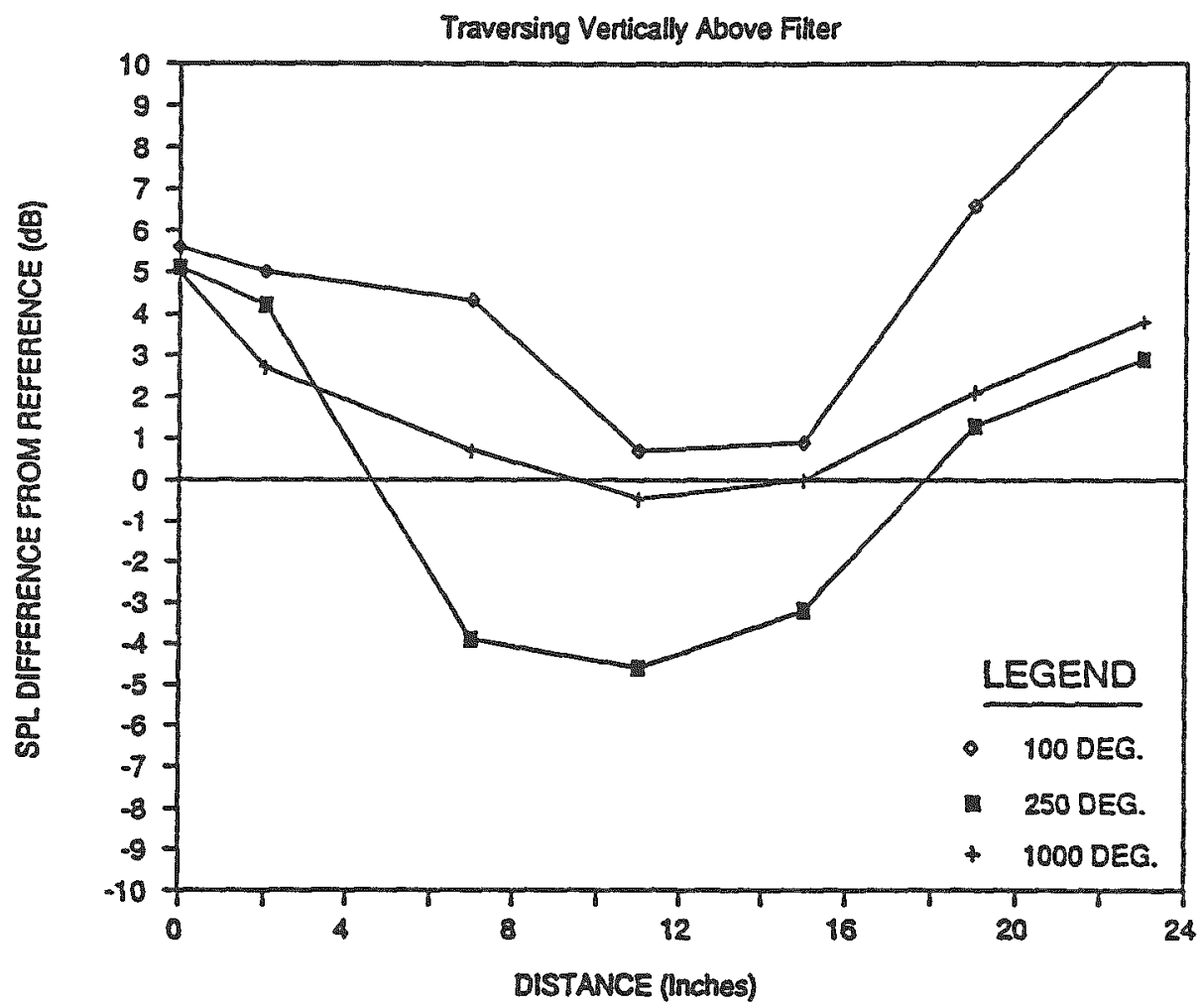

(a)

\section{NFF ACOUSTIC INSPECTION}

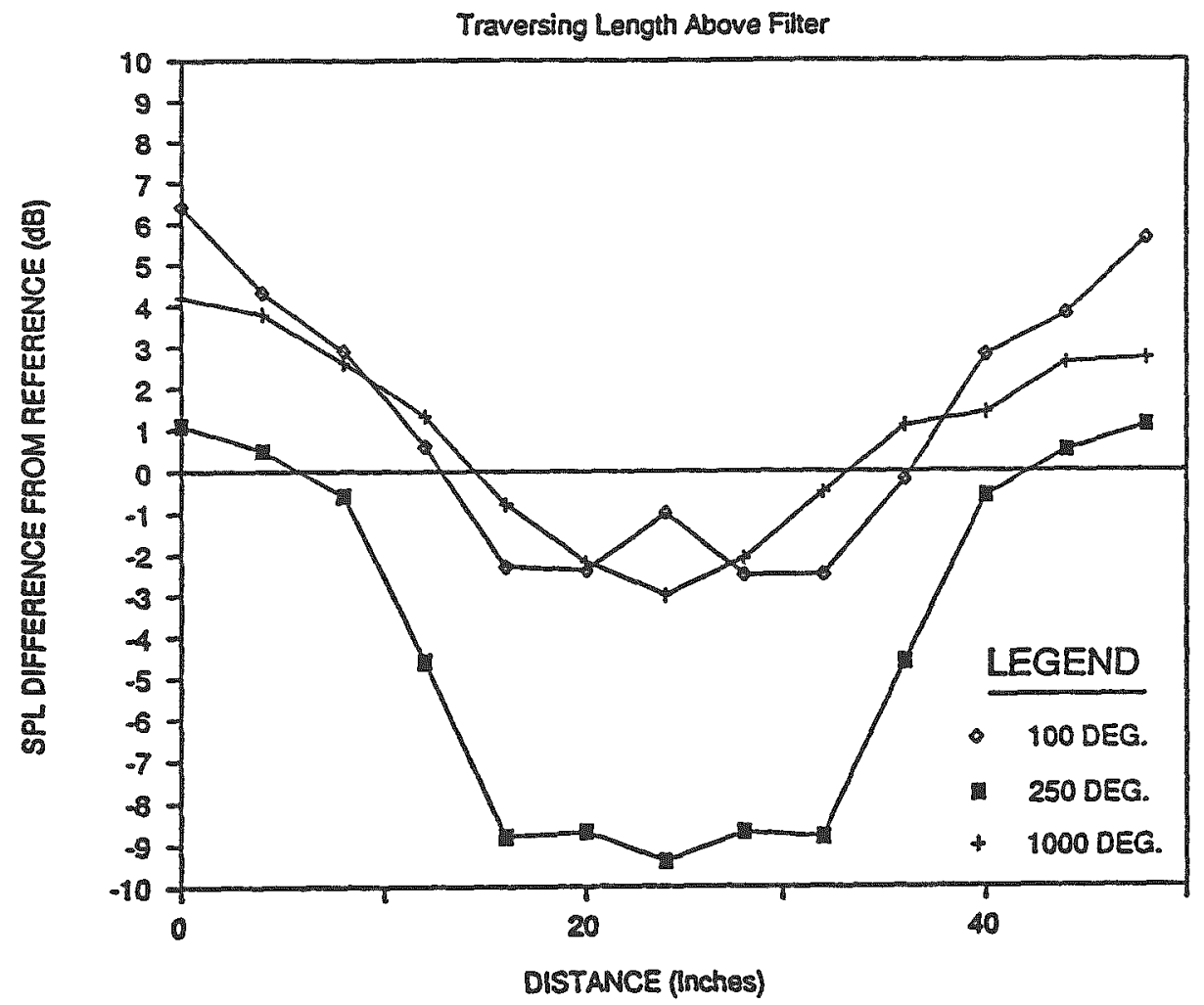

(b)

Figure 6. Traversining Horizontally Rather than Length 


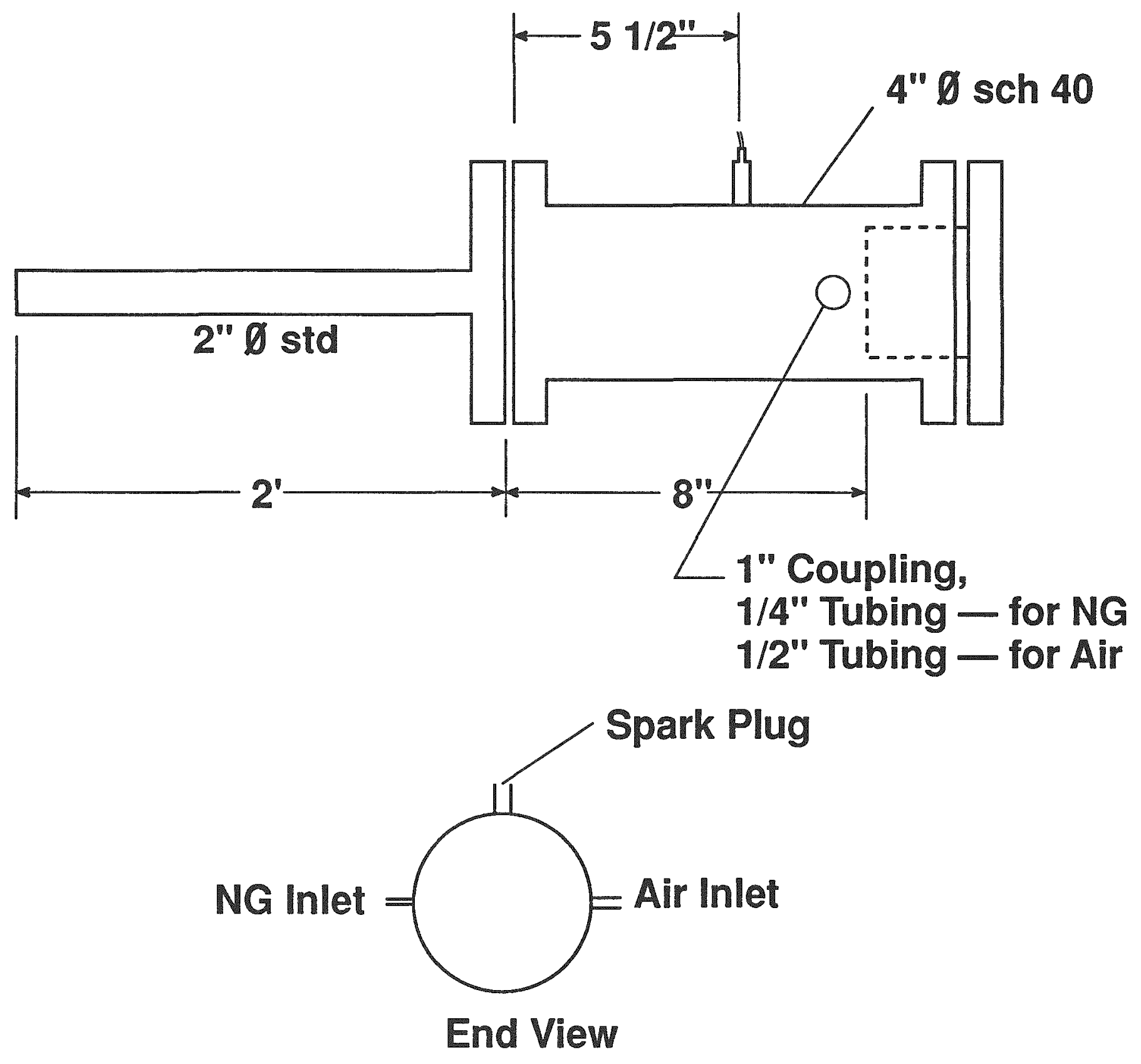

Figure 7. METC Pulse Combustor 


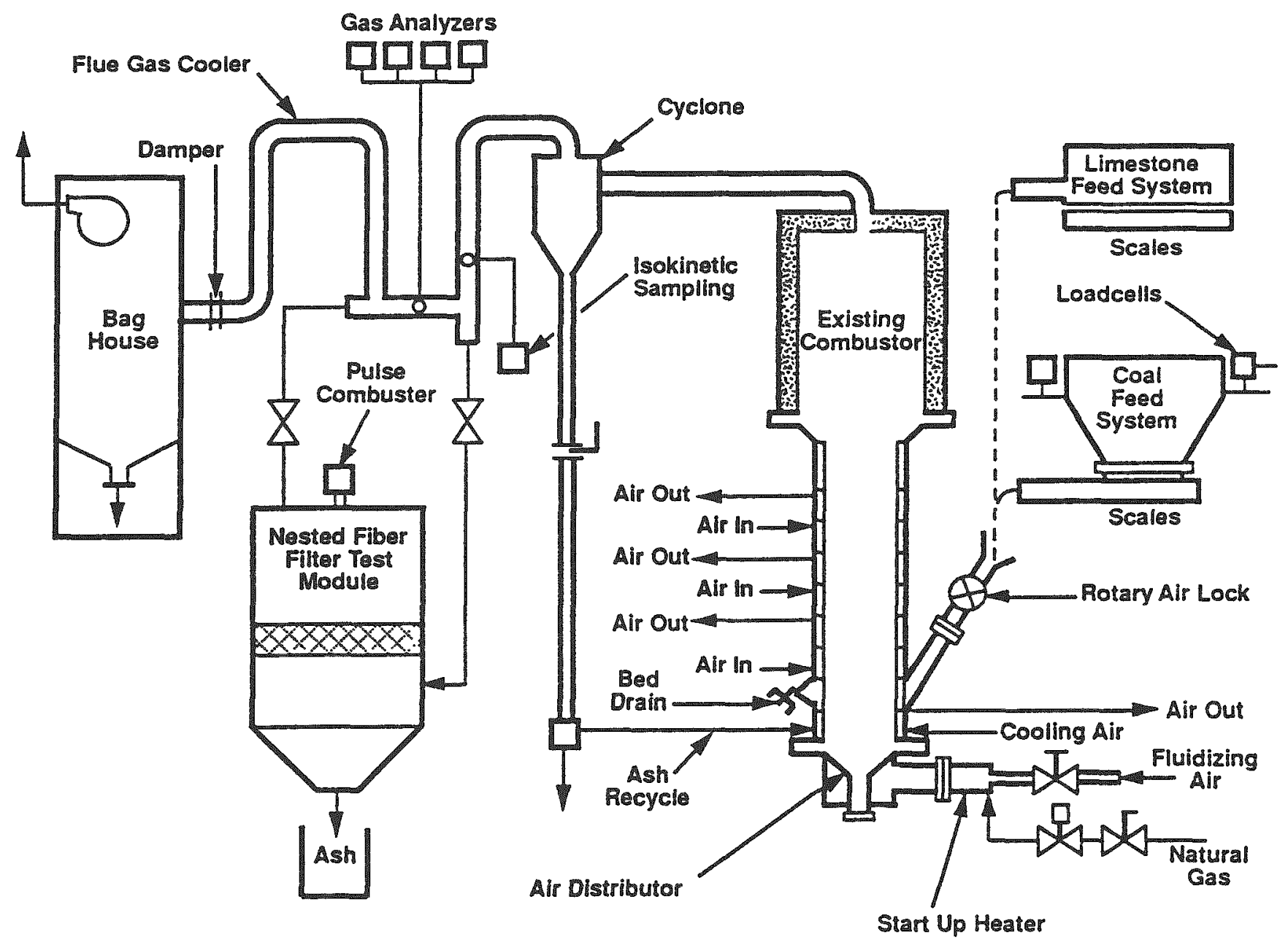

Figure 8. 24-Inch Fluidized Bed Facility 
as the final particulate control device. The NFF test module was installed with isolation valves and bypass to operate independent of the FBC. Operating conditions are provided in Table 2 and specific test conditions are reported in Appendix A.

\section{Test Results}

Results from Stage 1 testing are summarized in Table 3 and specific data for individual tests are presented in Appendix A. The initial tests provided equipment shakedown and problemsolving.

The focus on acoustic cleaning/regeneration performance involved evaluating alternate acoustic drivers and locations as previously described. Following the cleaning evaluation filter performance tests were conducted with the METC pulse combustor which was marginally effective in cleaning/ regenerating the NFF. Subsequent tests in Stages 2 and 3 evaluated both cleaning and filtration performance with a mechanical vibrator as the primary cleaning device.

\section{Acoustic Cleaning/Regeneration Performance}

The METC pulse combustor was evaluated to be marginally effective in cleaning/regeneration the NFF because of:

- Gradual increase in the reference $\Delta \mathrm{P}$ after cleaning

- Decreased time between cleanings (filtration duration)

- Particulate loss as monitored at the NFF outlet (discussed later). 
Table 2. FBC Operating Conditions

\begin{tabular}{|c|c|c|}
\hline & $6-\mathrm{ft}^{2} \mathrm{NFF}$ & $1.5-\mathrm{ft}^{2} \mathrm{NFF}$ \\
\hline Coal Feed Rate, lb/hr & 100 & 40 \\
\hline Limestone Feed Rate, $1 \mathrm{~b} / \mathrm{hr}$ & 50 & 32 \\
\hline Combustion Air Rate, $\mathrm{lb} / \mathrm{hr}$ & 1265 & 520 \\
\hline FBC Bed Level, iwc & $22-28$ & $22-28$ \\
\hline \multicolumn{3}{|l|}{ Temperatures } \\
\hline FBC Bed & 1700 & 1700 \\
\hline FBC Top & 1600 & 1250 \\
\hline \multicolumn{3}{|l|}{ Flue Gas Composition } \\
\hline $\mathrm{O}_{2}$ & $16.5 \%$ & $11.6 \%$ \\
\hline $\mathrm{CO}_{2}$ & $7.3 \%$ & $9.3 \%$ \\
\hline $\mathrm{CO}$ & $44 \mathrm{ppm}$ & $260 \mathrm{ppm}$ \\
\hline $\mathrm{SO}_{2}$ & $825 \mathrm{ppm}$ & $804 \mathrm{ppm}$ \\
\hline $\mathrm{NO}_{\mathrm{x}}$ & 93 ppm & 97 ppm \\
\hline
\end{tabular}


Table 3. Test Summary with Acoustic Cleaning (Stage 1)

\begin{tabular}{|c|c|c|c|c|c|c|c|}
\hline \multirow[t]{2}{*}{ Operating Conditions } & \multicolumn{7}{|c|}{ Test } \\
\hline & $5 / 13 / 91$ & $8 / 8 / 91$ & $8 / 9 / 91$ & $8 / 14 / 91$ & $8 / 16 / 91$ & $8 / 20 / 91$ & $9 / 12 / 91$ \\
\hline $\begin{array}{l}\text { NFF Basket } \\
\text { - Top Temp F }\end{array}$ & 1050 & 1000 & 1000 & 1100 & 1050 & 1100 & 1021 \\
\hline $\begin{array}{l}\text { NFF Basket } \\
\text { - Bottom Temp F }\end{array}$ & 1100 & 1200 & 1250 & 1160 & 1150 & 1200 & 1050 \\
\hline $\begin{array}{l}\text { NFF } d p \text { - Prior to cleaning } \\
\text { ("water) }\end{array}$ & 10 & 10 & 10.5 & 8 & 7.5 & 7 & 8 \\
\hline $\begin{array}{l}\text { NFF Filtration } \\
\text { Duration (min) } \\
\text { Number of cycles }\end{array}$ & $\begin{array}{l}120 \\
2 \\
\end{array}$ & $\begin{array}{l}60 \\
3 \\
\end{array}$ & $\begin{array}{l}60 \\
4\end{array}$ & $\begin{array}{l}20 \\
5 \\
\end{array}$ & $\begin{array}{l}20 \\
4\end{array}$ & $\begin{array}{l}15 \\
5 \\
\end{array}$ & $\begin{array}{l}15 \\
5\end{array}$ \\
\hline $\begin{array}{l}\text { Reference NFF dp after } \\
\text { cleaning ("water) }\end{array}$ & 8.5 & 2 & 3 & 2.5 & 5 & $4-6$ & 1.5 \\
\hline $\begin{array}{l}\text { Cleaning Duration (min) } \\
\text { Cleaning Device }\end{array}$ & $\begin{array}{c}5 \\
\text { Pulse }\end{array}$ & $\begin{array}{c}3 \\
\text { METC } \\
\text { Pulse } \\
\end{array}$ & $\begin{array}{c}3 \\
\text { METC } \\
\text { Pulse } \\
\end{array}$ & $\begin{array}{c}10 \\
\text { METC } \\
\text { Pulse } \\
\end{array}$ & $\begin{array}{c}3 \\
\text { METC } \\
\text { Pulse } \\
\end{array}$ & $\begin{array}{c}3 \\
\text { METC } \\
\text { Pulse } \\
\end{array}$ & $\begin{array}{c}10 \\
\text { METC } \\
\text { Pulse } \\
\end{array}$ \\
\hline Face Velocity ( $\mathrm{ft} / \mathrm{min})$ & 150 & 135 & 150 & 145 & 140 & 150 & 100 \\
\hline $\begin{array}{l}\text { Particulate Loading } \\
\text { - Inlet average (ppm) }\end{array}$ & & & & 2424 & & & 2424 \\
\hline $\begin{array}{l}\text { Particulate Loading } \\
\text { - Outlet (ppm) }\end{array}$ & & & & 40 & & & 103 \\
\hline Collection Efficiency (\%) & & & & 98.3 & & & 95.8 \\
\hline
\end{tabular}


A representative plot of filter $\Delta P$ versus time is shown in Figure 9. The pressure drop across the filter increases to a predetermined value ( $\sim 10$ inches water in this case) and then the filter is taken off line and cleaned. Typically the first filtration cycle $(A)$ of each day has a longer duration because the filter is heated to operating temperature concurrent with the filtration. The duration of each cycle (A, B, C, and D) decreases as the filter is loaded with captured particulate that are not removed consistently during the cleaning/regeneration cycle. The reference $\Delta \mathrm{P}$ after cleaning increases with each successive cycle which indicates that particulate are accumulating within the filter. Ideally the slope of this line (reference $\Delta \mathbb{P}$ after cleaning) should be zero and the time between cleanings should be nearly constant. These data indicate that the METC pulse combustor is able to marginally clean the NFF but the performance is decreasing with each successive cycle.

Several attempts were made to improve the cleaning effectiveness. Longer cleaning durations were tried (Tests $8 / 14 / 91$ and $9 / 12 / 91$ ) but did not significantly change the results. Different acoustic drivers were operated concurrently and consecutively without improving the cleaning effectiveness. These efforts led to the conclusion that the acoustic energy intensity $\left(\mathrm{Btu} / \mathrm{ft}^{2}\right)$ was too low for the 6- $\mathrm{ft}^{2}$ test module. Testing a smaller cross-sectional area was suggested as a critical experiment to confirm the conclusion. Stage 2 Tests with a $1.5-\mathrm{ft}^{2}$ cross-sectional area are described later.

\section{Filter Performance}

NFF filter performance was measured as the particulate collection efficiency:

$$
\eta=\left[1-\frac{\text { outlet loading }}{\text { inlet loading }}\right] \times 100 \%
$$

The inlet and outlet particulate mass loading was determined by isokinetic samples (EPA Method 5). An average value $\left(2424 \mathrm{ppm}, 2.9 \mathrm{gms} / \mathrm{m}^{3}\right)$ is used for the inlet particulate loading because the gas flow profile/velocity changed continuously during tests. The sample point was located 15 pipe diameters downstream of an elbow and primary cyclone which are suspected of causing swirling in 


\section{NFF 8/9/91}

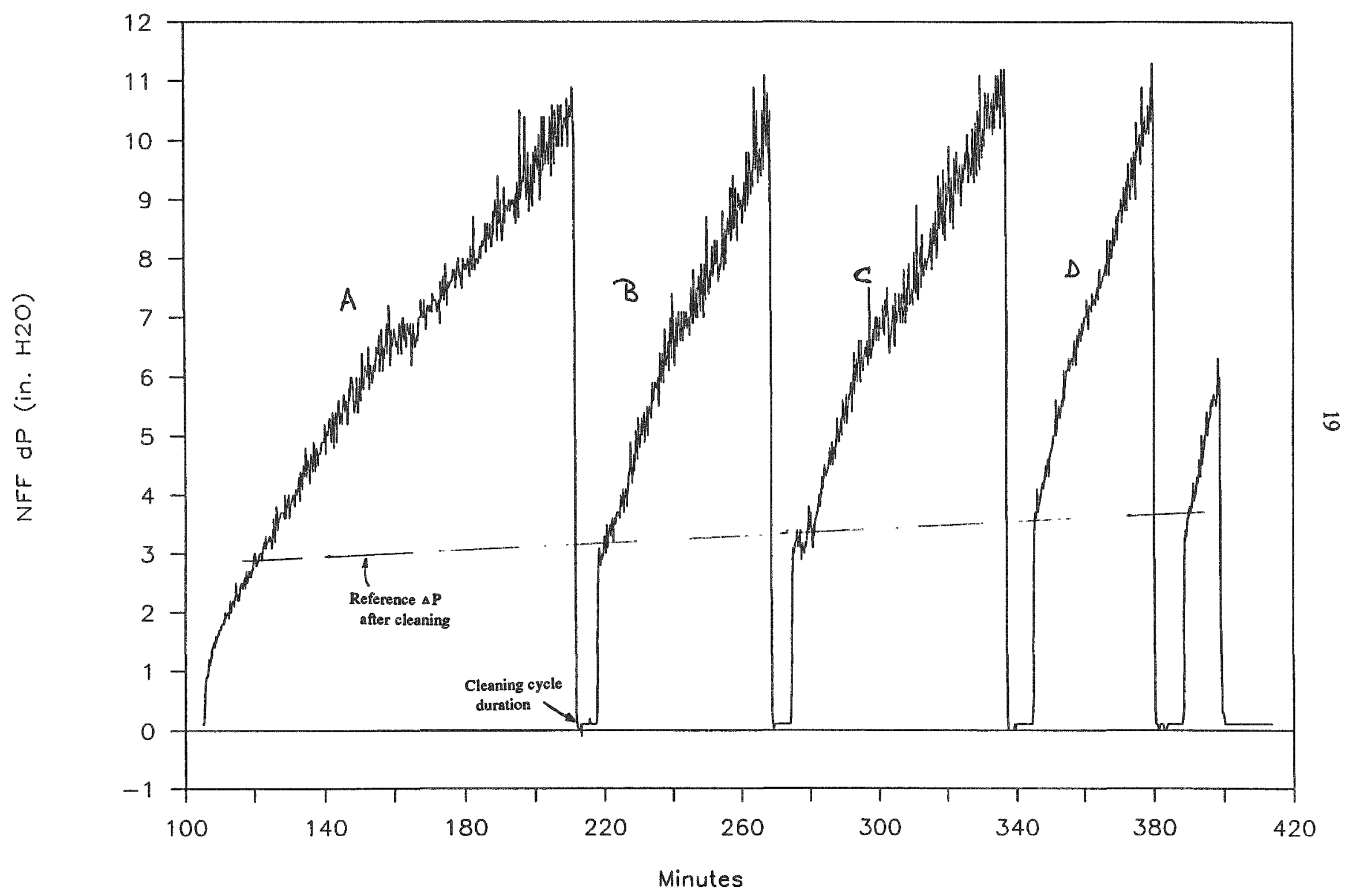

Figure 9. Filter $\Delta \mathbb{P}$ Versus Time 
the 8-inch pipe. Several samples and velocity traverses confirm the variations around the average value used in the calculations.

$\begin{array}{lr}\text { Highest value } & 5564 \mathrm{ppm} \\ \text { Average of } 7 \text { samples } & 2424 \mathrm{ppm} \\ \text { Lowest value } & 461 \mathrm{ppm} .\end{array}$

The outlet particulate loading was determined by high volume sampling of the 6-inch outlet pipe through a Method 5 cyclone and filter at $3 \mathrm{cfm}$. The high volume sampling was necessary to collect measurable quantities consistent with the filter durations. The data represent multiple consecutive cycles during a test to ensure sufficient particulate and gas volumes are collected for accurate measurement. The data in Appendix A are reported for specific tests and cycles.

The filter performance data summarized in Table 3 reveal that gas and particulate bypassing the NFF was a problem during some tests. Visual inspection of the NFF filter and test module between tests indicated bypassing along the walls of the basket where fibers had created a small void as a result of vibration during cleaning. A compressible glass-wool (Fiberfrax ${ }^{\circledR}$ ) gasket was used to minimize this problem with mixed results. On occasion the gasket seal would fail leading to gas bypassing and increased outlet particulate loadings.

Concern about analytical precision associated with particulate sampling in relatively small ducts prompted two background particulate measurements. The NFF outlet particulate loading was $0.9 \mathrm{ppm}$ when air was flowing through the test module without coal combustion in the FBC. The NFF outlet particulate loading was $1.6 \mathrm{ppm}$ when natural gas was fired to heat the FBC without coal or limestone feed. Both background measurements are sufficiently low to minimize concerns about errors in the outlet particulate loading resulting from background particulate or lack of precision in the sampling technique.

The aerodynamic particle size distribution of the NFF inlet stream was determined using an Andersen Impactor (Mark III). The particles were predominantly greater than $12 \mu \mathrm{m}$ which was the cut point for the preimpactor. The complete particle size distribution is presented in Table 4. 
Table 4. NFF Inlet Particle Size Distribution

\begin{tabular}{||c|c|c|c|}
\hline $\begin{array}{c}\text { Particle Size } \\
(\mathrm{mm})\end{array}$ & $\begin{array}{c}\text { Mass Collected } \\
\text { on Stage }(\mathrm{mg})\end{array}$ & $\begin{array}{c}\text { Percent Retained } \\
\text { on Stage }\end{array}$ & $\begin{array}{c}\text { Cumulative } \\
\text { Greater Than }\end{array}$ \\
\hline$>12$ & 195.9 & 61.9 & 61.9 \\
\hline$>9<12$ & 10.0 & 3.1 & 65.0 \\
\hline$>6.2<9$ & 39.8 & 12.6 & 77.6 \\
\hline$>3.2<6.2$ & 30.8 & 9.7 & 87.3 \\
\hline$>2.7<3.2$ & 21.0 & 6.6 & 93.9 \\
\hline$>1.4<2.7$ & 13.6 & 4.3 & 98.2 \\
\hline$>0.85<1.4$ & 3.0 & 0.9 & 99.1 \\
\hline$>0.58<0.85$ & 0.3 & 0.1 & 99.2 \\
\hline$<0.58$ & 2.2 & 0.7 & 99.9 \\
\hline
\end{tabular}

Extremely long sample times were necessary at the NFF outlet to get measurable quantities on individual stages; these samples could not be collected consistent with the relatively short filter duration of the tests. The preimpactor stage is a glass cyclone which provided a visual indication of filter performance. The low outlet particulate loadings (30-50 ppm) were collected when gas bypassing the filter was minimal. There were no large particles $(>12 \mu \mathrm{m})$ collected in the cyclone during these tests. A film of dust could be seen in the cyclone when the gas bypassing occurred and this observation is consistent with the lower collection efficiency and increased outlet particulate loading ( $>100 \mathrm{ppm}$ ). The particles greater than $12 \mu \mathrm{m}$ collected in the cyclone (preimpactor stage) were an indicator of the gas bypassing problem. This problem prevented determination of a meaningful particle size distribution for the NFF outlet. Previous tests without bypassing have shown all the outlet particles to be less than $3 \mu \mathrm{m}$.

\section{Reduced Cross-Sectional Area (Stage 2 Testing)}

The NFF cross-sectional area was reduced to $1.5 \mathrm{ft}^{2}\left(1^{\prime} \times 1.5^{\prime}\right)$ to obtain higher energy intensities with the acoustic cleaning devices. A pneumatic-mechanical vibrator was installed with the $1.5-\mathrm{ft}^{2}$ basket arrangement, mainly to support the primary cleaning devices in cleaning the NFF. Gas 
stops ("flat-stock @ $3^{n}$ intervals) were installed on all four walls of the fiber basket to eliminate (reduce) the gas bypassing. Gas bypassing was still a problem with this arrangement in tests with an 8-inch fiber bed depth.

Alternately, compressible fiberfrax gaskets were attached to the walls and the fibers were slightly compressed to reduce the potential voids at the walls. A schematic representation of the modified basket design is shown in Figure 10. In this design, the fiberfrax lined walls of the basket were expected to provide better contact with the fiber, eliminating voids formed during vibration. Also, at the top of the bed a gas-seal was ensured using a fiberfrax gasket and compression load in combination.

Table 5 presents a summary of operating conditions and results for tests 12-1 and 12-2. Seven consecutive particulate loading and cleaning cycles, spanning a 15 hour period, were successfully completed with the modified basket. For these tests, the face velocity was maintained at $\sim 200 \mathrm{ft} / \mathrm{min}$. Key test results and data interpretation are as follows:

The baseline dp of the NFF increased gradually to a constant value after a few initial cycles (see Figure 11), just as for the previous basket design. The slope of the $\mathrm{dp}$ measurements also increases during the first few operating cycles and then becomes fairly constant.

Basket cleaning in these tests was accomplished using a combination of cleaning devices. Typically in a cleaning cycle, the pulse combustor (located at the top of the NFF module) was operated for 10 minutes, followed by 3 to 5 minutes of mechanical vibration. This cleaning arrangement provided consistent cleaning of the basket.

Particulate collection efficiencies (reported in Table 5) indicate that the modified basket was extremely effective in cleaning the flue gas. Typically, the outlet gas particulate loading was less than $20 \mathrm{ppm}$. Unlike the previous test basket, very small quantities of particles were collected in the cyclone of the gas sampling line at the NFF outlet. This clearly indicates that gas by-passing does not occur. 


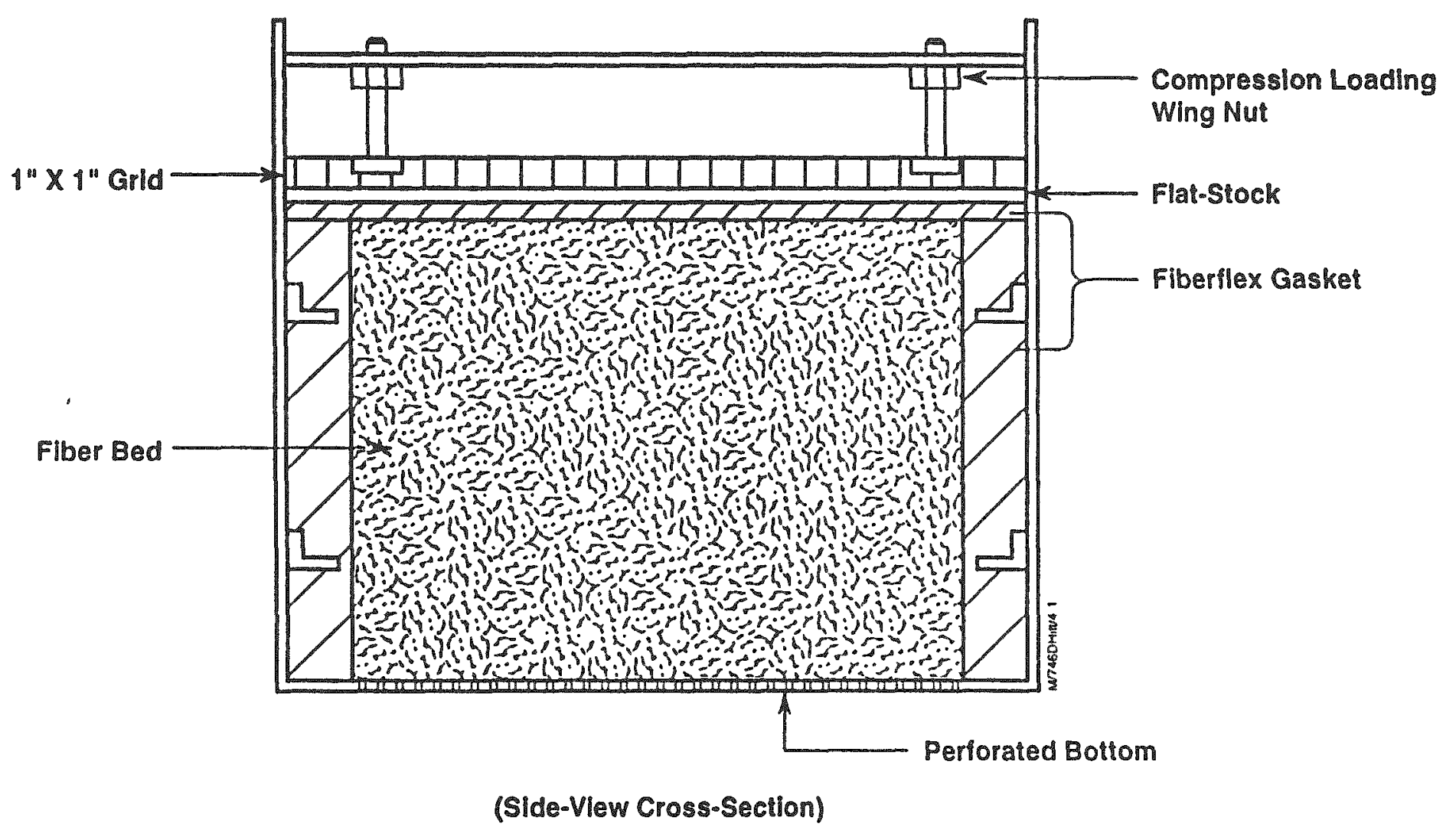

Figure 10. Schematic Representation of the Modified Basket Used in Tests 12-1 and 12-2 
Table 5. NFT Performance Results for Tests $12-1$ and $12-2: 1^{\prime} \times 1.5 ' \times 8^{\prime \prime}$ Modified Bed

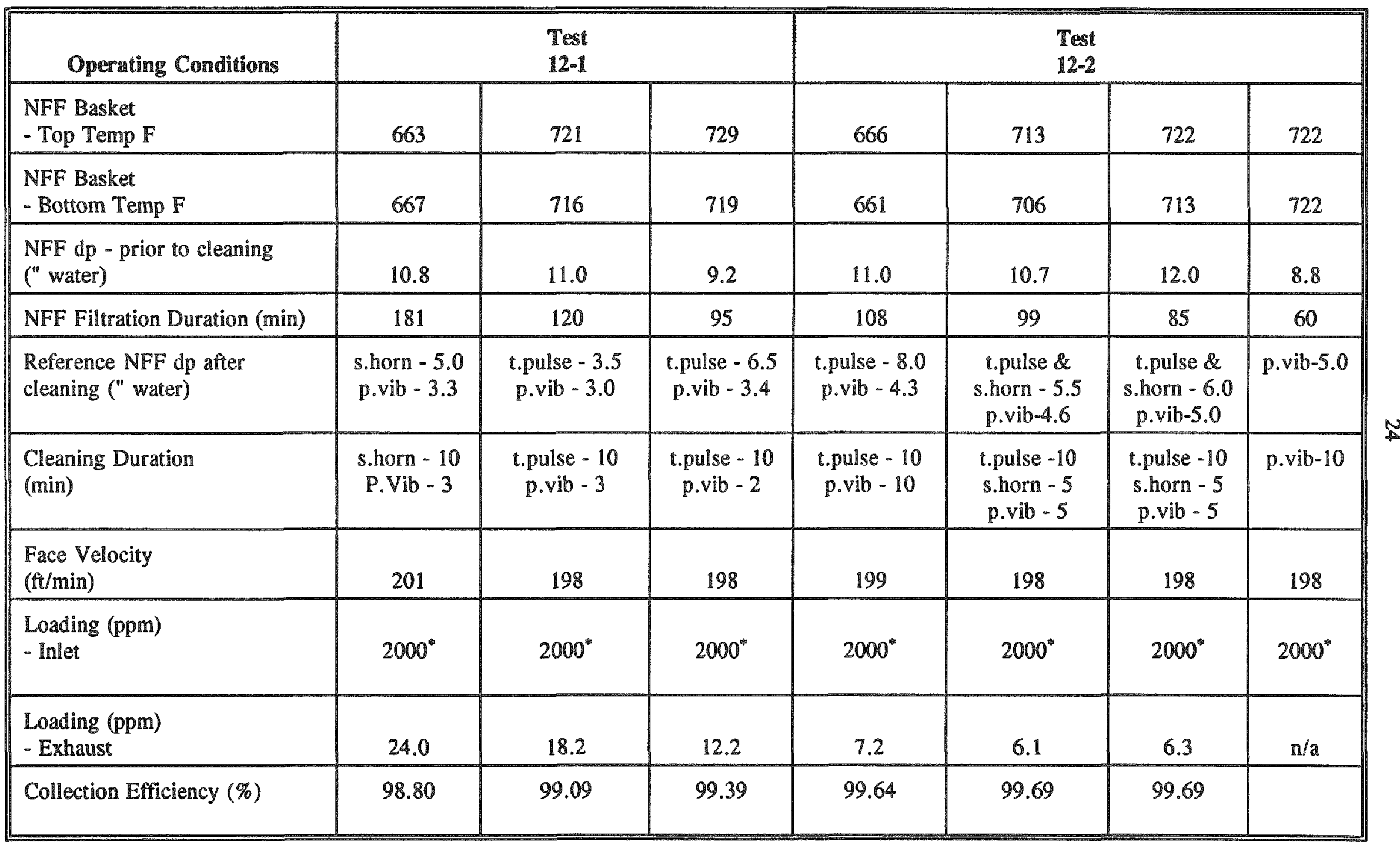

Note : All mechanical vibrator cleaning cycles in Test 12-2 was conducted with one vibrator.

* Average particulate loading. 


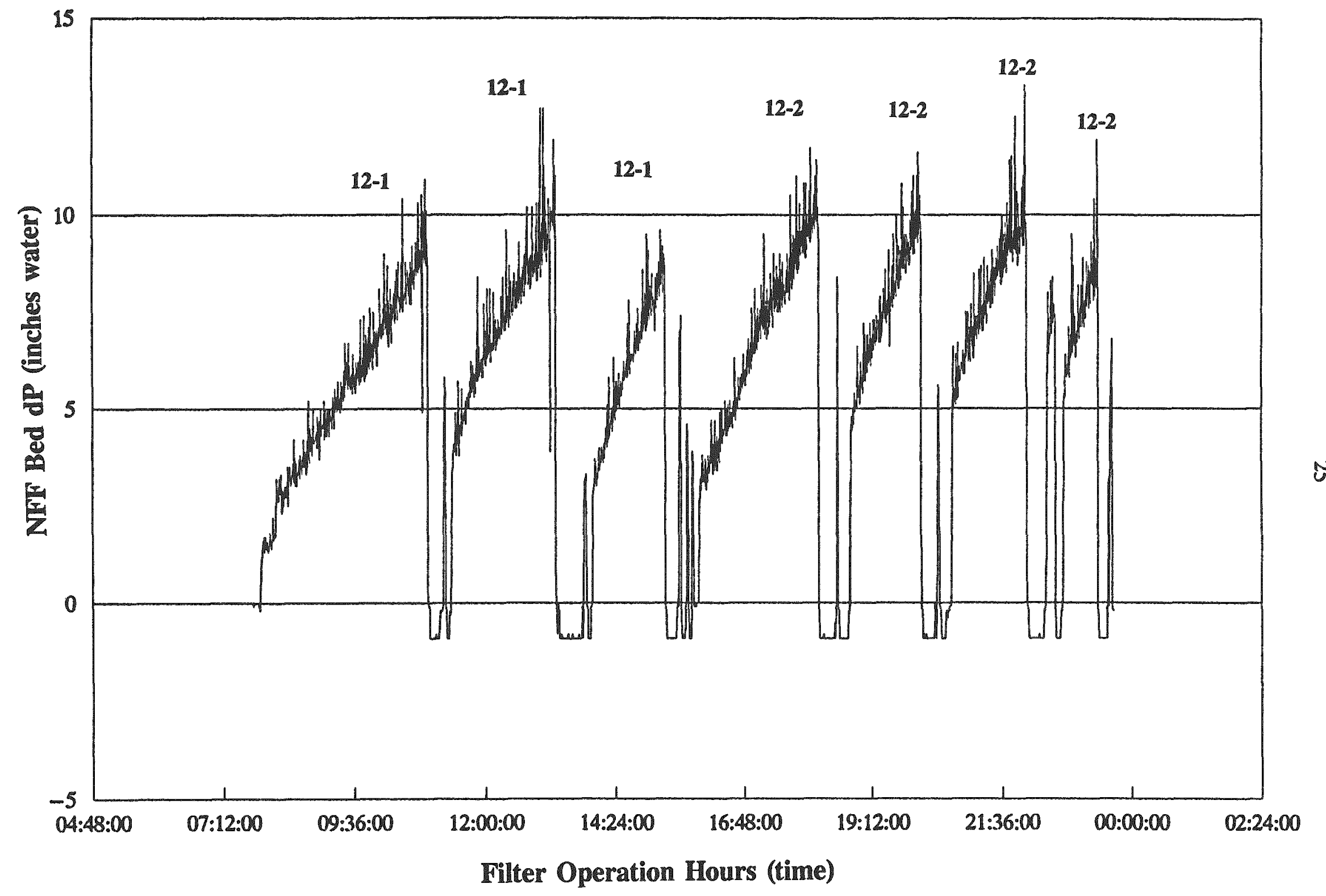

Figure 11. NFF Tests $\left(12-1\right.$ to 12-2):1' $\times 1.5^{\prime} \times 8^{\prime \prime}$ Bed 
Full-scale tests were resumed using mechanical vibration in combination with the pulse combustor for cleaning/regeneration. The $4^{\prime} \times 1.5^{\prime}$ NFF basket was prepared with a layer of fiberfrax gasket on all flat contact surfaces. The fibers were loaded to 12 " depth. The bed material was manually compressed and support bars were welded in place to hold the compression.

Two tests (1-1, 1-2) of 6 and 8 bed loading and cleaning cycles, were conducted with the $4^{\prime} \times 1.5^{\prime} \times 12^{\prime \prime}$ bed. For Test 1-1, the operational behavior of the NFF basket was similar to that observed with the small basket. However, in Test 1-2, the NFF bed was observed to deteriorate in filtration efficiency due to gas and particulate by-passing. Minor modifications were incorporated and Test 2-1 was conducted with fresh fibers in conjunction with alkali concentration measurement tests. Key results and interpretation of data from these two tests are presented below. Table 6 presents the NFF performance results for the $6-\mathrm{ft}^{2}$ tests with mechanical vibration cleaning.

- Figure 12 presents the NFF dp recorded during particulate loading and cleaning cycles for Test 1-1. The reference (baseline) dp after the cleaning cycles was observed to gradually increase from $2.3^{\prime \prime}$ to about $4.5^{\prime \prime} \mathrm{H}_{2} \mathrm{O}$ in the first 3 cycles of operation. In the remaining 3 cycles, after cleaning, the dp reached $\sim 4.5^{\prime \prime}$ $\mathrm{H}_{2} \mathrm{O}$, indicating a baseline or reference dp level of $\sim 4.5^{\prime \prime} \mathrm{H}_{2} \mathrm{O}$ can be maintained.

- Throughout this test, the mechanical vibrator was used as the main cleaning device. The vibrators performed satisfactorily for this large size basket. The pulse combustor located at the top of the bed was fired to provide a reverse gas flow to purge the particulates from the NFF and to maintain the NFF temperature.

- Particulate measurements recorded across the NFF basket, however, indicated 99.2 percent particulate collection. This is inferior to earlier results observed with the $1.5^{\prime} \times 1.0^{\prime}$ basket. Although damage to the gas seal was the suspected reason, Test 1-2 was initiated the next day to track the operational behavior of the basket over repeated loading and cleaning cycles.

- The NFF dp prior to cleaning was intentionally increased to 12 -inch $\mathrm{H}_{2} \mathrm{O}$ in Cycles $5,6,7$, and 8 . The reference dp had proportionally increased from 4.5 to about $6^{\prime \prime} \mathrm{H}_{2} \mathrm{O}$. This was expected since the cleaning duration was maintained at 10 to 15 minutes. 
Table 6. Test Summary with Mechanical Vibration Cleaning

\begin{tabular}{||l|c|c|c||}
\hline \multirow{2}{*}{ Operating Conditions } & \multicolumn{3}{|c|}{ Test } \\
\cline { 2 - 4 } & $1-1 / 93$ & $1-2 / 93$ & $2-1 / 93$ \\
\hline $\begin{array}{l}\text { NFF Basket } \\
\text { - Top Temp F }\end{array}$ & 1050 & 1050 & 1100 \\
\hline $\begin{array}{l}\text { NFF Basket } \\
\text { - Bottom Temp F }\end{array}$ & 1170 & 1170 & 1180 \\
\hline $\begin{array}{l}\text { NFF dp - Prior to cleaning } \\
\text { ('water) }\end{array}$ & 10 & $10-12$ & 11 \\
\hline $\begin{array}{l}\text { NFF Filtration } \\
\text { Duration (min) } \\
\text { Number of cycles }\end{array}$ & 30 & 20 & 30 \\
\hline $\begin{array}{l}\text { Reference NFF dp after } \\
\text { cleaning ("water) }\end{array}$ & 6 & 8 & 8 \\
\hline $\begin{array}{l}\text { Cleaning Duration (min) } \\
\text { Cleaning Device }\end{array}$ & 20 & 6 & 4 \\
\hline Face Velocity (ft/min) & 200 & 195 & 195 \\
\hline $\begin{array}{l}\text { Particulate Loading } \\
\text { - Inlet average (ppm) }\end{array}$ & 2424 & 2424 & 2424 \\
\hline $\begin{array}{l}\text { Particulate Loading } \\
\text { - Outlet (ppm) }\end{array}$ & 99.2 & 91.5 & 99.1 \\
\hline Collection Efficiency (\%) & Combination & Combination & Combination \\
\hline \hline
\end{tabular}


NFF 1-1 TEST : $4^{\prime} \times 1^{1.5}$ BED

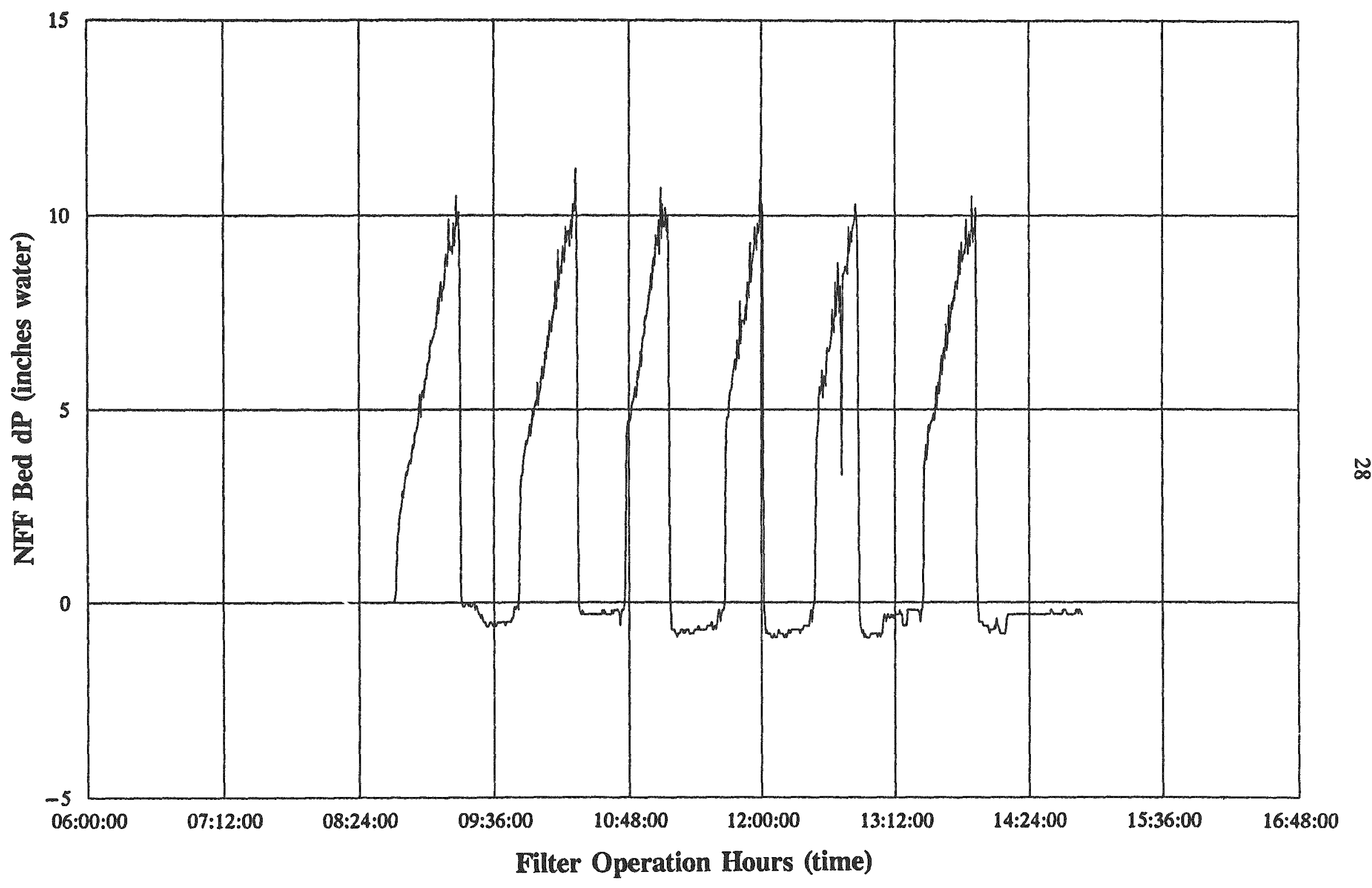

Figure 12. $d p$ Profiles During 'Test 1-1, With $4^{\prime} \times 1.5^{\prime} \times 12^{\prime \prime}$ NFF Basket 
- Particulate measurements across the bed showed deteriorating filtration performance. The efficiency had decreased to 91 percent. In addition, particulate matter was clearly visible at the sampling cyclone. This indicated that the gas seal was damaged and particulate matter was bypassing the bed.

Post-test inspection showed clear evidence of gas bypassing. In addition, the restraints used to hold the compression load over the basket-surface had failed. Due to the repeated vibration during bed cleaning, the bed material was subjected to compaction. The initial compression load was, therefore, gradually lost allowing particulates to bypass the bed. Thus, it was clear that it is necessary to maintain the compression load to achieve a gas seal.

Following these two tests, fiber material was removed from the basket and fresh fibers were reloaded in the $6-\mathrm{ft}^{2}$ basket. The basket was then sealed at the edges with fiberfrax gasket. The compression load was maintained by a reinforced arrangement used earlier in $1.5^{\circ} \times 1.0$ basket test. Test 2-1 of eight filter loading and cleaning cycles was conducted over a ten-hour time period. Alkali concentration levels at the exit side of the NFF basket was successfully monitored by Ames

Laboratory lowa State University during this test. Since the fluid bed was operated at $1.0-1.5 \mathrm{psi}$, operational difficulties were experienced, limiting the alkali measurements only at the exit side.

Nevertheless, particulate measurements were obtained during the test. In the first few operating cycles, the NFF basket's gas-seal was maintained, providing good particulate capture. With continued loading and consequent mechanical vibrational cleaning, the gas-seal was damaged leading to poor particulate capture. Other filter performance results are presented below.

Particulate collection efficiencies of the order of 99.1 percent was achieved in this test. No traces of particulate matter was visually evident in the sampling cyclone, during the first six operating cycles, indicating proper gas-seal.

In Cycles 7 and 8 (last two cycles of particulate loading) of the test, during particulate sampling, a dark ring of particulate matter was visually evident in the cyclone (not seen in Cycles $\# 1-6$ ). Particulate collection efficiencies for these two cycles were only about 88.8 percent. The compression load on the basket surface may have been darnaged during the repeated vibrational cleaning and also due to higher operating pressure, causing the gas and particulate bypassing. Consequently, the particulates find a path of least resistance, affecting the collection performance of the bed.

The gas and particulate seal arrangement used in the modified 6- $\mathrm{tt}^{2}$ basket of Stage 3 testing was not completely successful. This could be attributed to the following reasons: 
Insufficient or loss of compression load on the top of basket

No gas-stops were used along the basket walls (unlike the Stage 2 test with $1.5 \mathrm{ft}^{2}$ basket)

Intense mechanical vibration.

In conclusion, from the limited number of Stage 3 tests, it is obvious a better and more reliable sealing arrangement is necessary. Although mechanical vibration of cleaning/regeneration was successful, more research is necessary to quantify and relate the mechanical vibrational intensities with cleaning. Basket redesign and continued testing based on the results achieved in this program is crucially needed to further the NFF demonstration.

\section{Testing of Various Acoustical Sources for Cleaning Nested Fiber Filter}

Preliminary acoustical testing was performed on the NFF facility with 8 " bed depth and vertical baffles installed to reduce the cross-sectional area of the bed to approximately $1.5 \mathrm{ft}^{2}$. This represents a reduction in cross-sectional area by a factor of four. The acoustic horn output showed a $10 \mathrm{~dB}$ gain with the baffles installed. The SPL (Sound Pressure Level) at the peak output (about 165 $\mathrm{Hz}$ ) was $149 \mathrm{~dB}$ with the reduced area. The maximum SPL measured above the original large filter bed $\left(6 \mathrm{ft}^{2}\right)$ was approximately $139 \mathrm{~dB}$. This is an increase by a factor of eight in terms of sound intensity. The highest output measured on the small scale tests ( 4 " diameter basket) was about 160 $\mathrm{dB}$, when the only effective cleaning was observed. These experiments established that the SPL required for cleaning was between 150 and $160 \mathrm{~dB}$ with a harmonic driver at 130 to $200 \mathrm{~Hz}$.

A second test was conducted with the baffles removed. The other difference was that this test was on an operating filter and the previous test was at ambient temperatures and no dust loading in the filter bed. The peak amplitude measured from the horn was only $133 \mathrm{~dB}$ at $170 \mathrm{~Hz}$. This is about $15 \mathrm{~dB}$ less than the level measured with the baffles. A comparison of the two measurements can be seen in Figure 13. Notice that the second harmonic is approximately the same amplitude for both measurements. This suggests that the horn was not operating at peak efficiency. Only the peak amplitude dropped significantly.

The shift in fundamental frequency probably is due to the difference in temperature between the two tests. According to previous tests, the SPL should be about $138 \mathrm{~dB}$ without the 


\section{ACOUSTIC HORN OUTPUT \\ With and Without Vertical Baffles}

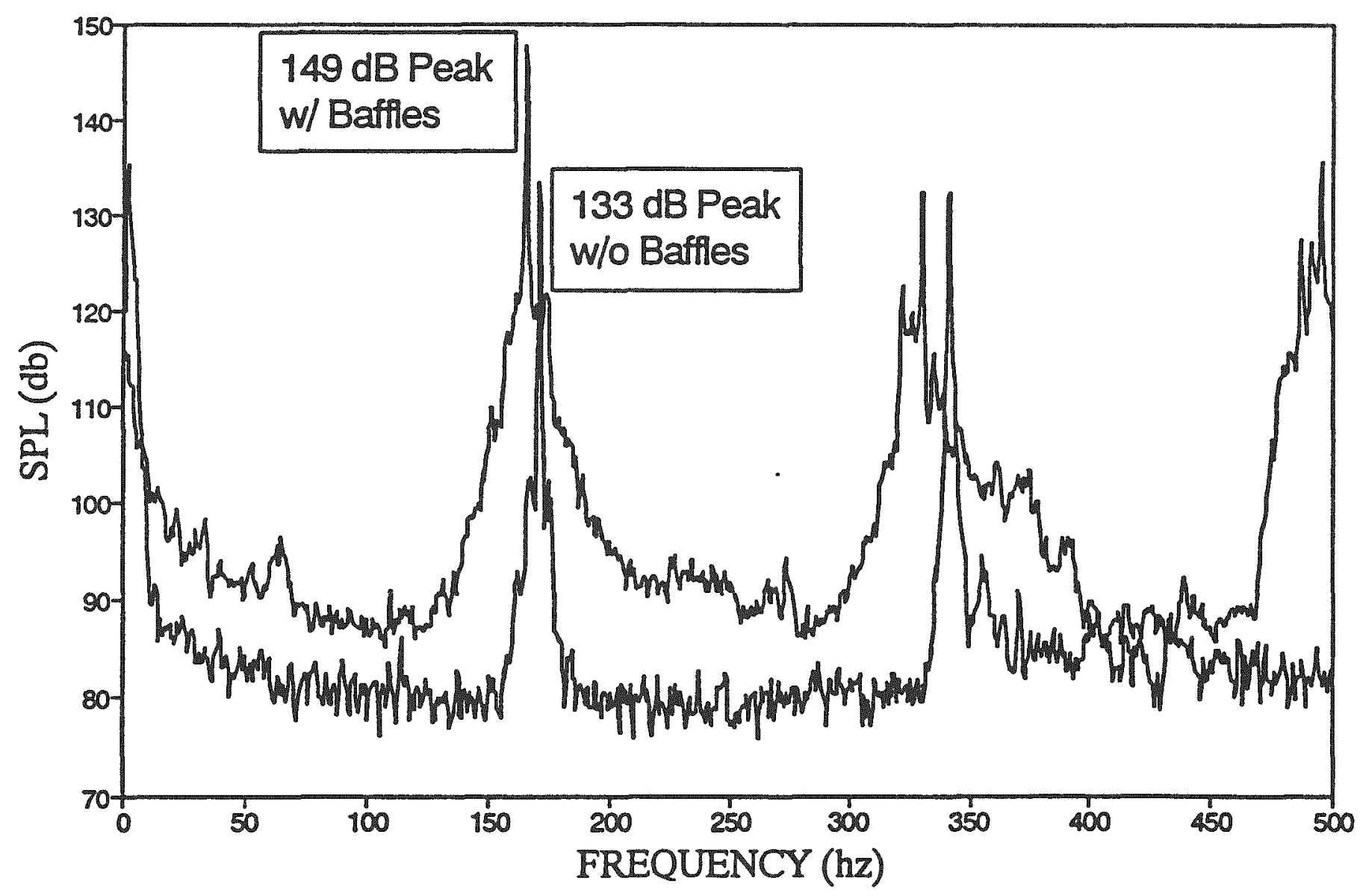

Figure 13. Frequency Response Plot for Measured SPL of Acoustic Horn With and Without Bafles. Recorded at Room Temperature Conditions 
vertical baffles. The horn air supply (and purge air) needs to be optimized to get the horn to operate efficiently.

The important analysis is the comparison of the acoustical sources. Frequency response measurements for the acoustic horn (Figure 14), small pulse combustor on top (Figure 15), large pulse combustor on bottom chamber backfiring (Figure 16), and the large (METC) pulse combustor running smoothly (Figure 17) provided some interesting results. From earlier testing and published references on baghouse cleaning using acoustic sources, the best frequency range for cleaning is probably between 150 and $350 \mathrm{~Hz}$. Only fixed-frequency sources are available for cleaning because a resonant device is needed for extremely high acoustical energy output. Looking at the frequency response measurements for the four sources provides some insight into which should be the most effective cleaning device. The measurements are time averaged (approximately 20 seconds). This is helpful in providing comparisons because the pulse combustor backfired much less frequently than the other harmonic sources. With averaging, a good comparison can be made for long term signal content, which is required for cleaning. For each of the frequency response curves, the integrated SPL within various frequency bands was calculated. The tabulated results are:

\begin{tabular}{lcccc}
\multicolumn{1}{c}{ Device } & Location & $0-500 \mathrm{~Hz}$ & $100-400 \mathrm{~Hz}$ & $150-350 \mathrm{~Hz}$ \\
Acoustic Horn & Top & 166.5 & 163 & 162.5 \\
Small Pulse Combustor & Top & 163 & 160 & 157 \\
$\begin{array}{l}\text { Large Pulse Combustor } \\
\text { (Backfiring) }\end{array}$ & Bottom & 169.5 & 160.7 & 154.5 \\
$\begin{array}{l}\text { Large Pulse Combustor } \\
\text { (Running smoothly) }\end{array}$ & Bottom & 159.3 & 153 & 145.5
\end{tabular}

According to the above table, the acoustic horn produces the highest SPL of the four. The small pulse combustor and the large backfiring pulse combustor are fairly even. The backfiring pulse combustor actually was the highest over the entire $500 \mathrm{~Hz}$ frequency range, but significant fraction of the energy was below $100 \mathrm{~Hz}$. It is not known if energy at that low frequency can be helpful for cleaning, other than previous attempts to clean with just air flow have not been successful.

The conclusion is that to achieve successful cleaning in a $1.5 \mathrm{ft}$ square chamber, more acoustic energy is required. There are several horns available that are optimized for this size chamber and can provide an increase of $10 \mathrm{db}$ over the presently used horn. It is also possible that a 


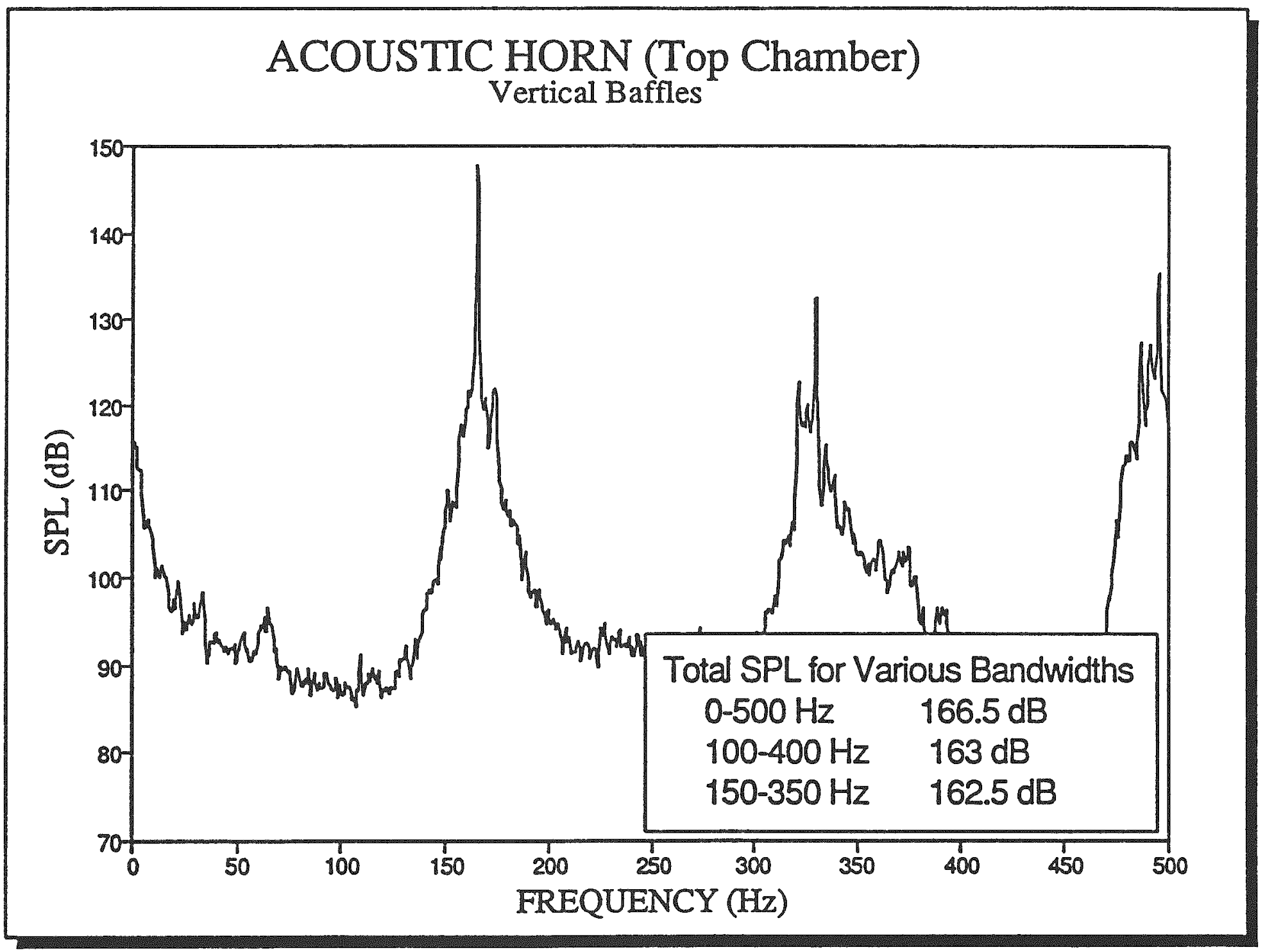

Figure 14. Frequency Response Plot for Measured SPL of Acoustic Ilorn Mounted on Top Chamber of NFF. 


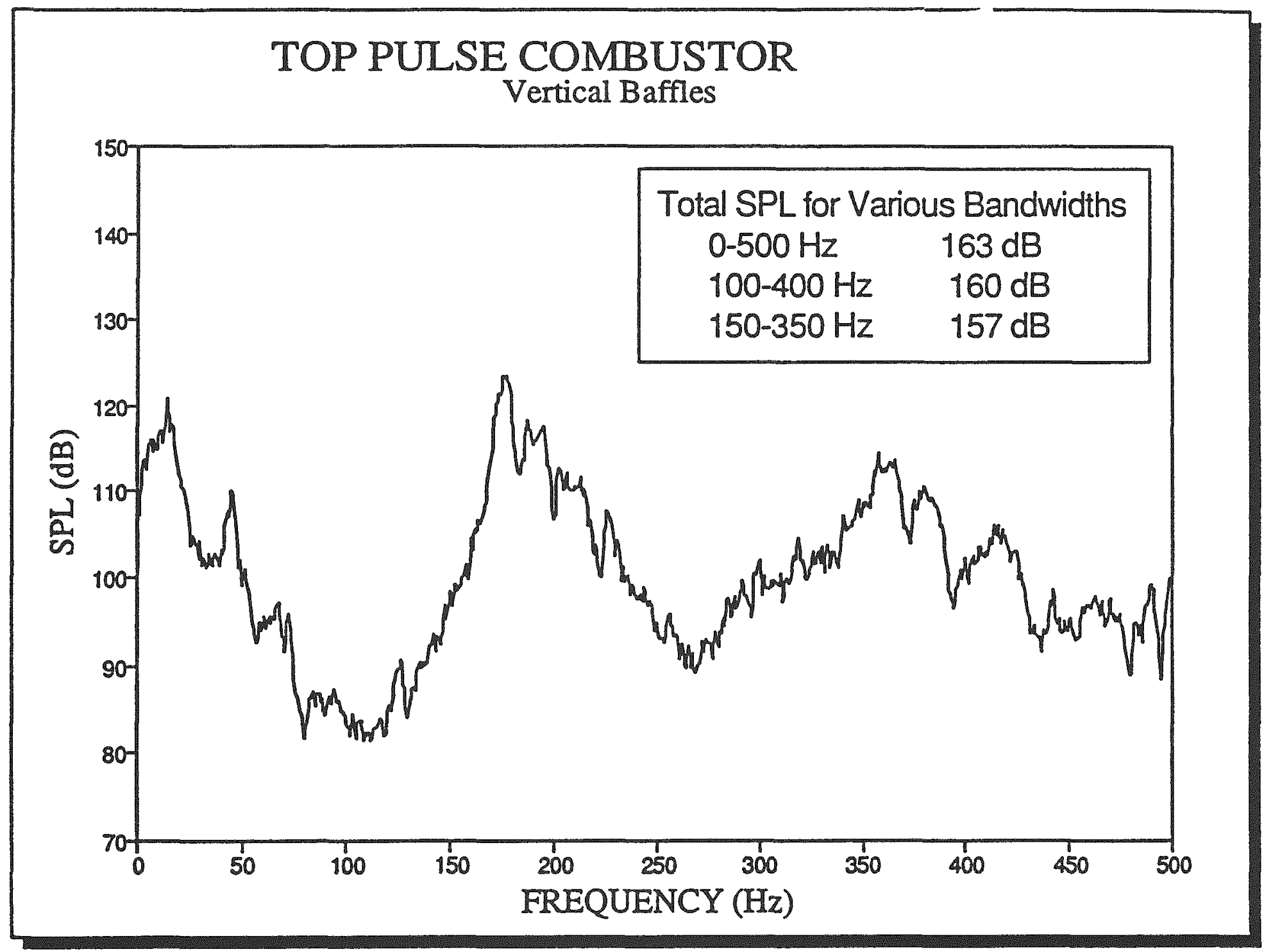

Figure 15. Frequency Response Plot for Measured SPL of Small Pulse Combustor Mounted on Top Chamber of NFT. 


\section{BOTTOM PULSE COMBUSTOR (Backfiring) \\ Vertical Baffles}

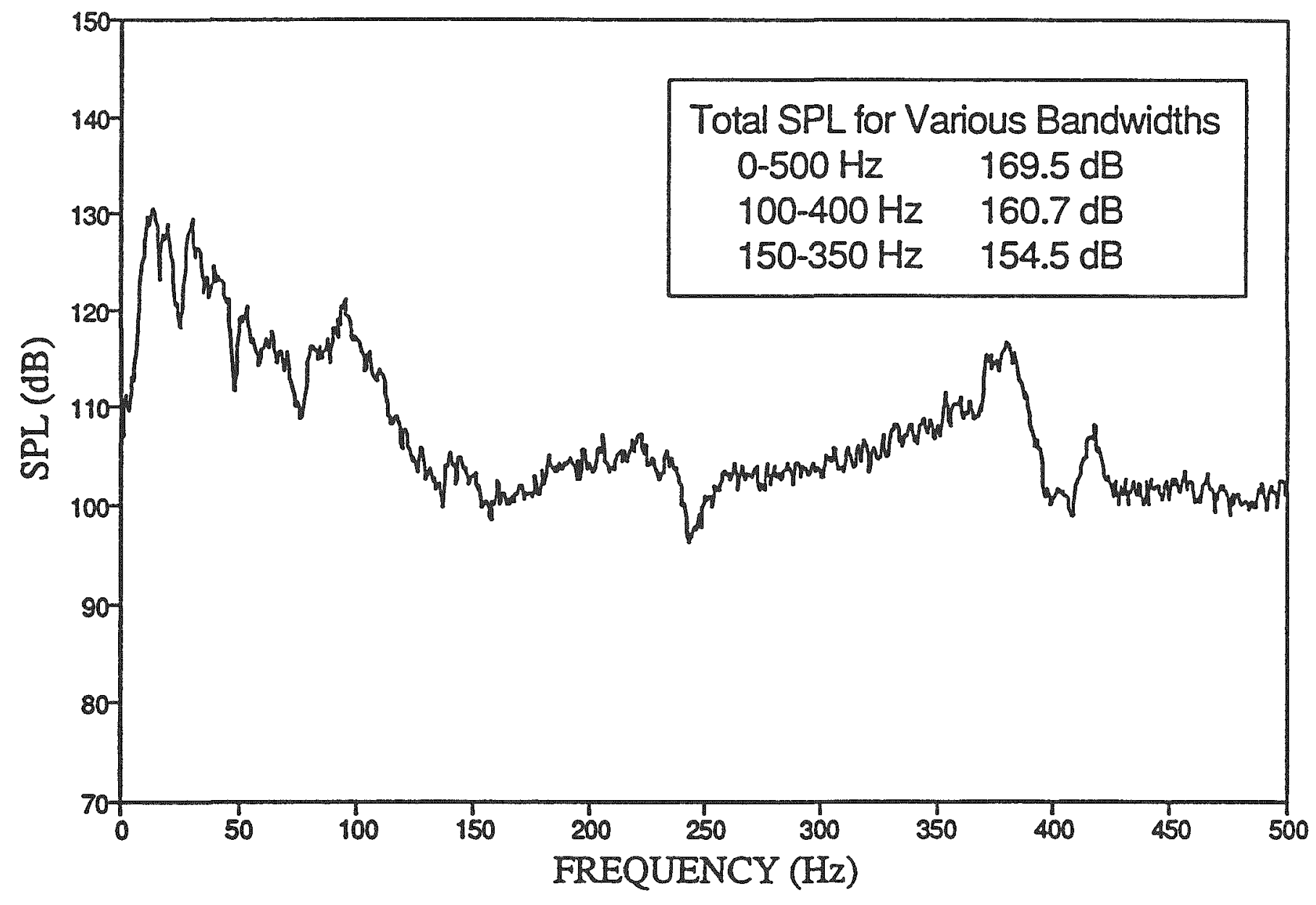

Figure 16. Frequency Response Plot for Measured SPL of Backfiring Large Pulse Combustor Mounted on Lower Chamber of NFF. 


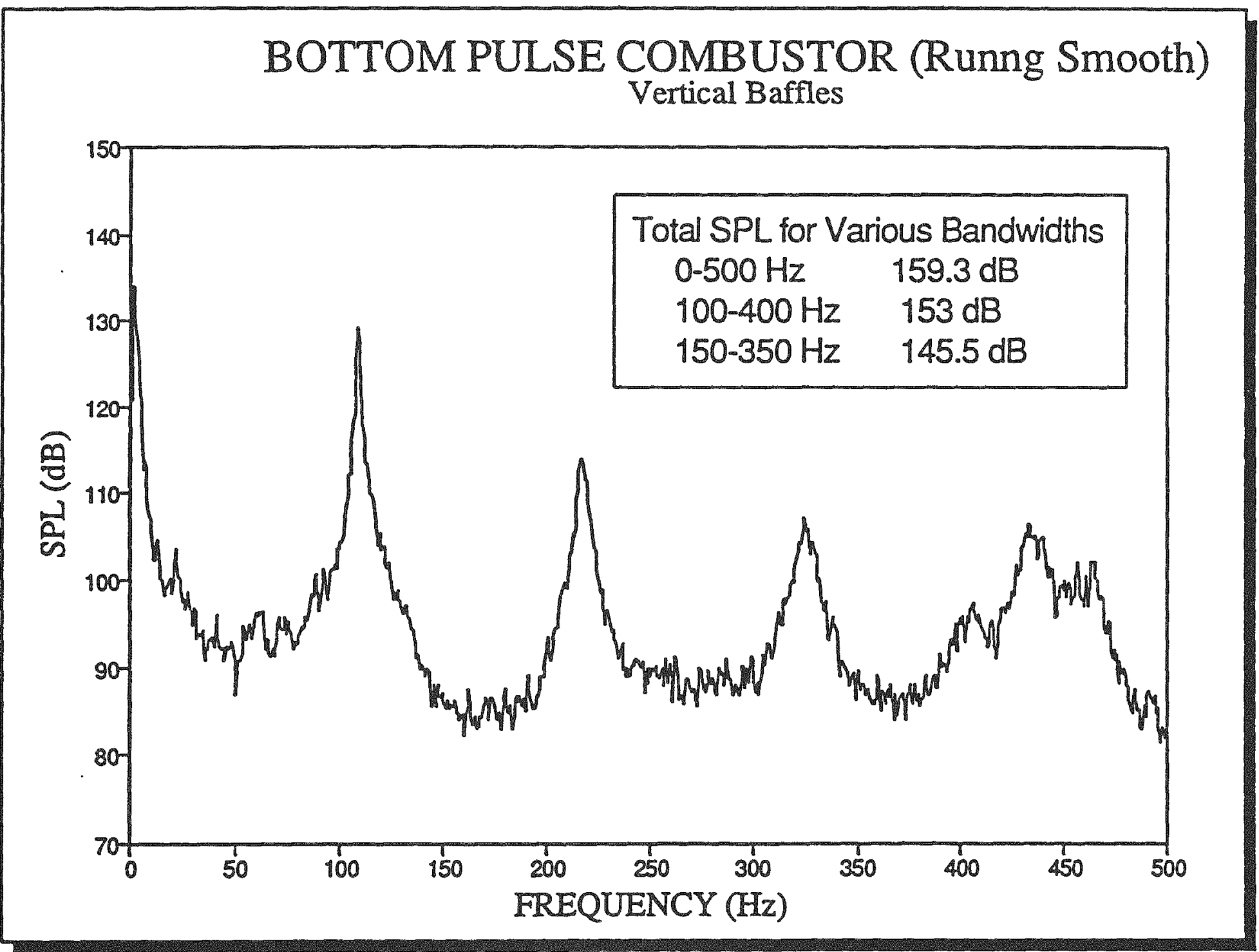

Figure 17. Frequency Response Plot for Measured SPL of Large Pulse Combustor Ruming Smoothly, Mounted on Lower Chamber of NFF. 
pulse combustor could be designed for more acoustic output. However, it is likely that the $\left(1.5 \mathrm{ft}^{2}\right.$ filter bed) is the largest area filter that could be cleaned with an acoustic device. A large filter bed would require a great deal of acoustic sources and the expense may be difficult to justify. 


\section{Engineering and Economic Evaluation}

The engineering and economic evaluation of the NFF was prepared consistent with a previous DOE evaluation of 10 High-Temperature, High-Pressure Particulate Filters. ${ }^{(2)}$ Costs were escalated to January 1993. Maximum use of similar components and costs were used to be consistent with the previous DOE evaluation as described later.

The design basis for the evaluation was as follows:

$330 \mathrm{MW}$ Pressurized Fluidized Bed Combustion (PFBC)

1650 F Combustion Temperature

25,809 ppm particulate (14.2 gr/SCF) at the PFBC exit.

Emission less than $0.03 \mathrm{lb} / 10^{6} \mathrm{Btu}$ input or approximately 0.015 grain/SCF (30 ppmw) to meet EPA's New Source Performance Standards.

This design basis requiring use of two PFBC and gas turbine modules is slightly different from that used in the previous DOE study where three parallel modules were used. The size of each component and module is maintained because the differences are small and within the accuracy of the design/performance data and cost estimates. The emphasis on consistency was preferred at this early evaluation to compare the results with alternative technologies.

\section{Conceptual Design}

The conceptual design for a single module PFBC system is shown in Figure 18. ${ }^{(3)}$ This general process schematic shows the relationship of the Nested Fiber Filter to the other major PFBC components. Two (2) parallel pressure vessels each containing four parallel NFF compartments, as shown in Figure 19, remove the particulate for turbine specifications and the EPA emission requirements. Conventional 6-ft diameter cyclones are used upstream of the NFF to provide a gross 77.5 percent reduction in particulate loading from $25,809 \mathrm{ppm}$ at the PFBC exit to $5809 \mathrm{ppm}$ at the NFF inlet. ${ }^{(3)}$ The cyclone is expected to remove particles greater than $50 \mu \mathrm{m}$. Using cyclones as a precleanup stage prior to the NFF increases the time between cleaning and takes advantage of the NFF ability to remove the fine particulate, $<50 \mu \mathrm{m}$. 


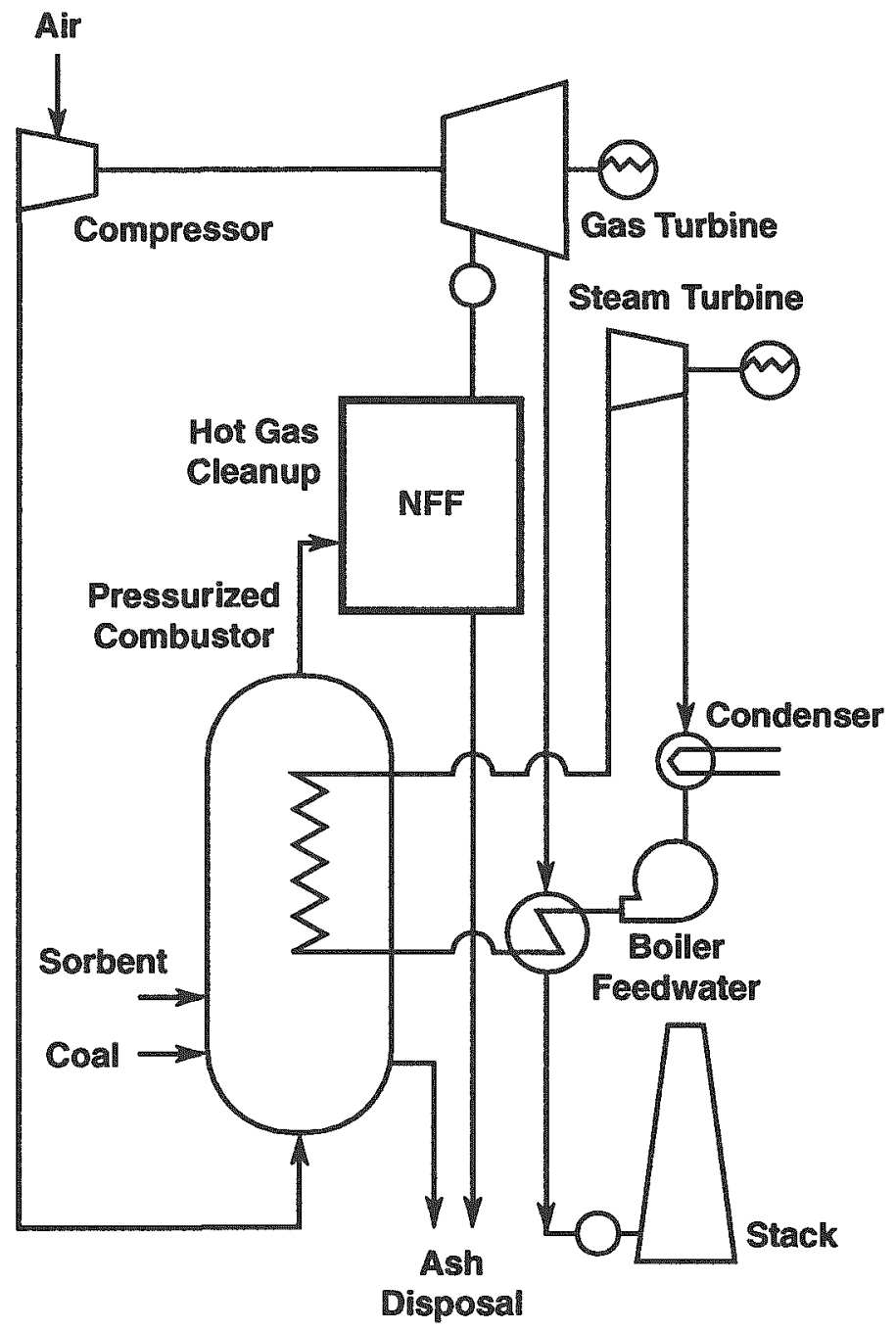

M746LLItf05-4

Figure 18. PFBC Steam Cooled System 


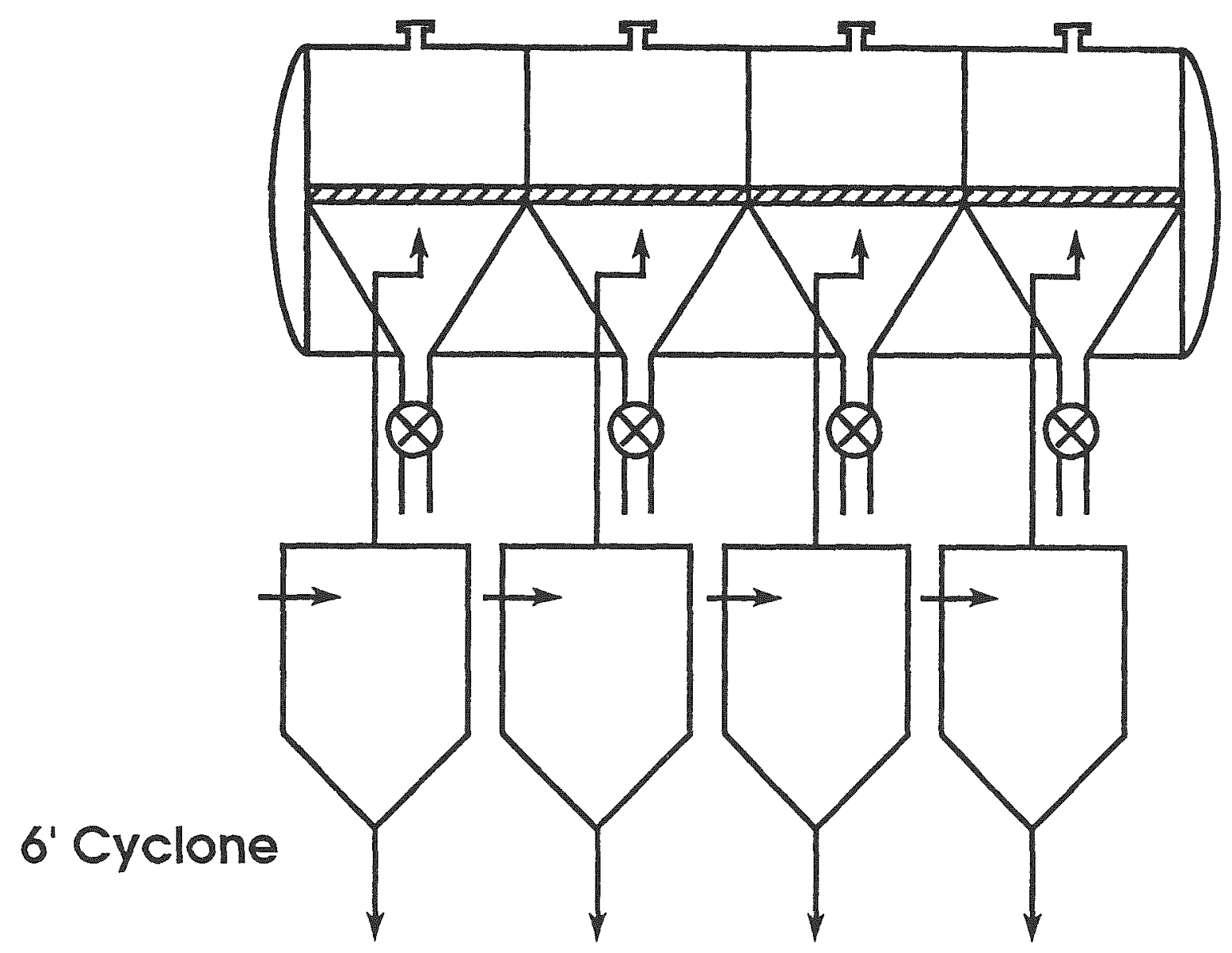

13-1/2 OD

37 ' Long

3 Compartments

Filtering

1 Cleaning

Figure 19. Battelle NFF Horizontal Configuration 
The four parallel NFF compartments are contained in a single pressure vessel $13.5 \mathrm{ft}$ OD $\times 37$ feet long. Offline cleaning of one compartment is possible while three compartments are in service at any given time. Sequential cleaning is provided by combined acoustic (pulse combustor) and mechanical vibration. Isolation valves are required at the NFF outlet port since the low particulate concentration $(<30 \mathrm{ppm}$ ) reduces the erosion and plugging problems relative to the inlet. Ash is removed by gravity through a lock hopper discharge system.

Each NFF compartment has an 8-ft x 12-ft cross-sectional area with a 12-inch fiber bed depth. The fibers are supported on perforated metal grids made of RA333 or equivalent material. The fibers are compressed slightly with a hold down grid to minimize voids as a result of the cleaning vibrations. Four natural gas fired pulse combustors are located above each compartment of the NFF bed to provide reverse-hot gas flow during the cleaning cycle. The pulse combustor design is a scaled-up version of the METC pulse combustor. Four mechanical vibrators are connected to each compartment to operate in combination with the pulse combustors. The mechanical vibrators are commercial models (VMS 1500 from the Cleveland Vibrator Company). Some local cooling is required to keep the moving parts of the vibrator below $1200 \mathrm{~F}$.

The face velocity with this arrangement is approximately $200 \mathrm{ft} / \mathrm{min}$ with three compartments in parallel service. The pressure drop is 3 inches water column (iwc) when the filter is clean and increases to $10 \mathrm{iwc}$ at which time the compartment is isolated and cleaned. The mean time between cleaning is 30 minutes and the cleaning cycle is 3 minutes.

\section{Capital Cost}

Capital costs were estimated consistent with the previous DOE study and cost elements from that study were used to the extent possible. This represents a non-optimum design and cost estimate for the NFF but the preliminary nature of the evaluation includes sufficient contingencies that minimize the overall impact. Costs from the DOE evaluation are presented in Table 7 with the mid1983 cost basis and the updated 1993 cost which reflects an escalation factor of 1.129 based on the Chemical Engineering Plant Cost Index ${ }^{(4)}$ (July $83=316.2$, December $92=357.0$ ).

Costs for the precleanup cyclone, pressure vessel, support structure including internal grid and baffles and other components such as valves and piping were used from the DOE evaluation. Costs for the stainless steel fibers were based on a quote from Ribtec who is a current manufacturer. 
Table 7. Capital Cost Estimate

\begin{tabular}{|c|c|c|c|c|c|}
\hline \multirow[b]{2}{*}{ Component } & \multirow[b]{2}{*}{ Reference } & \multicolumn{2}{|c|}{ Unit Cost $(\$ 1000)$} & \multirow[b]{2}{*}{ Quantity } & \multirow{2}{*}{$\begin{array}{c}\text { Process } \\
\text { Equipment } \\
\text { Cost }(\$ 1000)\end{array}$} \\
\hline & & 1983 & 1993 & & \\
\hline $\begin{array}{l}\text { Precleanup Cyclone } \\
\left(6^{\prime} \phi\right)\end{array}$ & $7-25$ & 104 & 117.5 & 16 & 1,878 \\
\hline $\begin{array}{l}\text { Pressure Vessel } \\
\left(13.5^{\prime} \text { OD x } 37^{\prime}\right)\end{array}$ & $7-31$ & 239.6 & 270.5 & 4 & 1,082 \\
\hline Support Structure & $7-32$ & 275 & 310.5 & 4 & 1,242 \\
\hline Fibers (310SS) & Ribtec & & $14 /$ ton & $25 /$ ton & 350 \\
\hline Pulse Combustors/Vibrators & $\begin{array}{l}\text { Cleveland } \\
\text { Vibrator }\end{array}$ & & 3 & 32 & 160 \\
\hline $\begin{array}{l}\text { Other Components } \\
\text { (valves, piping) }\end{array}$ & $7-33$ & 480 & 542 & 4 & 2,168 \\
\hline \multicolumn{5}{|c|}{ Subtotal NFF } & 6,880 \\
\hline Ash Handling & D-36 & 1085 & 1225 & 4 & 4,900 \\
\hline $\begin{array}{l}\text { Auxiliary Systems } \\
\text { (compressed air, utilities) }\end{array}$ & $\mathrm{D}-36$ & 235 & 265 & 1 & 265 \\
\hline Hot Gas Piping & D-36 & 5372 & 6065 & 1 & 6,065 \\
\hline Foundations & D-36 & 2850 & 3217 & 1 & 3,217 \\
\hline \multicolumn{5}{|c|}{ Total Direct Cost } & 21,327 \\
\hline \multicolumn{6}{|c|}{ Indirect Costs } \\
\hline $\begin{array}{l}\text { Construction } \\
\text { Engineering } \\
\text { Owners Cost } \\
\text { Project Contingency } \\
\text { Process Contingency } \\
\text { Escalation } \\
\text { Funds During Construction }\end{array}$ & $\begin{array}{l}D-7 \\
D-7 \\
D-7 \\
D-8 \\
D-8 \\
D-8 \\
D-8\end{array}$ & & & & $\begin{array}{l}2,825 \\
1,249 \\
1,112 \\
4,265 \\
4,265 \\
3,710 \\
4,158 \\
\end{array}$ \\
\hline \multicolumn{5}{|c|}{ Total Costs (Direct + Indirect) } & $\$ 42,911$ \\
\hline
\end{tabular}

* Reference is DOE report page number unless vendor is identified. 
Costs for the pulse combustors and mechanical vibrators were estimated from components materials and a quote from the Cleveland Vibrator Company. The subtotal equipment cost for the NFF is estimated to be $\$ 6,880,000$ for a $330 \mathrm{MW}$ plant. Other direct costs for ash handling, compressed air, cooling, electrical power, hot gas piping, and foundations were also used from the DOE evaluation. The sum of these process equipment components provides a total direct cost for the particulate control system of approximately $\$ 21.3$ million.

Indirect costs for construction, engineering, owners cost, contingency, escalation and working capital were estimated consistent with the DOE evaluation. The indirect construction labor was 80 percent of the direct labor cost. System engineering was 5.8 percent of the total direct equipment cost. The owner related cost was 4 percent of the total field cost (sum of total direct and indirect labor cost). A 20 percent project contingency was applied to the total field cost to reflect the uncertainty associated with a preliminary design. A 20 percent process contingency was applied because the NFF represents a developing technology with limited experimental data. This contingency is frequently used in an effort to quantify the uncertainty in technical performance involved with scaleup from pilot plant to commercial scale operation. Escalation of 8 percent per year was applied for the construction period which was estimated at 57 months. An allowance for funds used during construction was 10 percent per year.

The total of the direct and indirect costs for the particulate control system is approximately $\$ 42.9$ million. This is equivalent to $\$ 130 / \mathrm{kW}$ which compares to values of $\$ 61 / \mathrm{kW}$ to $\$ 147 / \mathrm{kW}$ for the ten devices in the previous DOE evaluation.

The total capital cost for the PFBC, gas turbine, steam turbine and boiler was $\$ 1013 / \mathrm{kW}$ in 1983 which corresponds to $\$ 1144 / \mathrm{kW}$ in 1993 . The resulting total plant cost for the PFBC system with a NFF would be $\$ 1274 / \mathrm{kW}$. This compares to values of $\$ 1261 / \mathrm{kW}$ for the ceramic cross-flow filter and $\$ 1341 / \mathrm{kW}$ for a moving granular bed filter. The NFF is competitive with these alternative approaches for high-temperature, high-pressure particulate control.

The plant operating costs are expected to be less for the NFF, compared to porous ceramic filters, because of significantly lower pressure drop. A general rule of thumb has been that 1-inch of water pressure drop represents approximately $\$ 1$ million in operating cost over the life of the plant. 


\section{Conclusions and Recommendations}

Development of the Nested Fiber Filter has progressed to a $6-\mathrm{ft}^{2}$ test module operating with a representative particulate-laden gas from a fluidized bed combustor. Several conclusions can be drawn from the tests and experience gained.

Tests show particulate capture efficiency greater than 99 percent can be achieved when gas bypassing does not occur.

Identified gas and particulate bypassing in scale-up testing.

Need to modify the NFF test module to eliminate the gas bypassing by designing vertical walls compatible with the fibers and maintaining compressive force on the fibers.

Mechanical vibration combined with pulse combustor can clean/regenerate the NFF over a limited number of cycles.

- Acoustic cleaning was not effective as an independent method at the 6- $\mathrm{ft}^{2}$ scale. The pulse combustor was used effectively in combination with mechanical vibration.

Extended operation is required to estimate the life of an NFF and associated performance.

- Preliminary engineering and economic evaluation of the NFF shows that it is a cost-competitive alternative to porous ceramic filters. Also, design for manufacturing may provide additional cost savings.

Tests 1-1 and 2-1 showed the excellent particulate capture efficiency of the NFF over a cumulative time of 15 hours and 14 cycles. The outlet particulate loadings were 44 and $22 \mathrm{ppm}$, respectively with an average inlet loading of approximately $2424 \mathrm{ppm}$. Mechanical vibration was combined with a pulse combustor to clean the NFF after the differential pressure (dp) reached 10-12 inches water column. Cleaning durations of 10 to 20 minutes returned the dp to $\sim 4$ inches water at the beginning of the next cycle. The face velocity was approximately $200 \mathrm{ft} / \mathrm{min}$ for these tests. It may be possible to modify the face velocity, cleaning duration, dp prior to cleaning and dp after cleaning to achieve equivalent or improved operation. 
Gas and particulate bypassing was a problem during several tests. Gas stops at the walls and compressed fiberfrax insulation provided a partial solution to the bypassing problem. The fibers were placed under compression load when installed in the filter. The NFF operation was successful as long as the compressive load was maintained so voids would not form at the walls. Additional development and testing is needed to reliably overcome the gas and particulate bypassing problem during extended operation.

Mechanical vibration combined with the pulse combustor provided effective cleaning/regeneration of the NFF. The number of consecutive cycles with the NFF was limited by the gas/particulate bypassing. The fibers were dumped and reloading after bypassing was detected although this may not be required in every case. A pneumatic vibrator (Model $1150 \mathrm{VMS}$ ) rated for 1 ton capacity was used in the $6-\mathrm{ft}^{2}$ tests. The manufacturer has a Model 1500 which is rated at 100 tons that would be the largest commercially available vibrator to use. This large model is projected to match a $5^{\circ} \times 5^{\circ} \times 12^{\prime \prime}$ section of a commercial system. A $1200 \mathrm{~F}$ temperature limit would require positioning the vibrator so the local temperature can be maintained below $1200 \mathrm{~F}$.

Acoustic vibrators were not effective in cleaning the $6-\mathrm{ft}^{2}$ NFF module without the mechanical vibrator. The METC pulse combustor was used in combination with the mechanical vibrator to achieve effective cleaning. The pulse combustor provided a source of hot gas in reverse flow to aid the cleaning. The acoustic intensity of both the pulse combustor and the sonic horn were lower than previous small-scale tests. Coupling the acoustic driver to test module is necessary to achieve maximum acoustic intensity. Sound pressure levels of $139 \mathrm{db}$ were achieved but levels greater than $150 \mathrm{db}$ are projected as necessary to effectively clean the NFF. Large acoustic drivers with this SPL are not readily available for commercial applications and require additional development and testing.

The pilot plant operated over a limited number of consecutive hours and cycles. Additional cycles are needed to demonstrate high reliability required for commercial applications.

The preliminary engineering and economic evaluation indicates that the NFF is cost competitive with the leading candidates (porous ceramic filters) for the high-temperature, highpressure applications. The evaluation used a previous DOE study for consistent comparison with ten alternative devices and the NFF had a capital cost of $\$ 130 / \mathrm{kW}$. The total plant cost for a PFBC system including the NFF is estimated to be $\$ 1274 / \mathrm{kW}$. The comparable value for a PFBC with a ceramic cross-flow filter would be $\$ 1261 / \mathrm{kW}$. 


\section{Recommendations}

Additional research and development is needed to demonstrate extended operation of the NFF with reliable performance meeting the requirements of commercial high-temperature, highpressure applications. The particulate capture efficiency needs to be maintained at greater than 99 percent with outlet particulate loadings less than $30 \mathrm{ppm}$. It is necessary to overcome the gas and particulate bypassing problem to achieve this requirement. Results to date indicate that a solution is possible but not yet complete. Recommendations for continued R\&D are:

- Evaluate alternative methods of maintaining gas and particulate seal across the $\mathrm{NFF}$, and

Examine the feasibility of using high intensity acoustic drivers for fiber cleaning.

One approach to achieve an effective seal is to sinter fibers (nominally 1 -inch thick) as a wall lining that is compatible with the fiber bed. The wall lining would be sintered at moderate temperature (2200 F) so the voidage is maintained. Another alternative would be to imbed some fibers into a refractory wall insulation. Again the goal is to have compatibility of the wall (material) and the fibers. Tests of alternative designs could provide an empirical evaluation with long-term testing of the design which successfully overcomes the bypassing problem. Participation of an industrial partner with a manufacturing perspective would be beneficial in selecting a design that solves the problem without undue economic penalty. Design modifications with the inlet gas manifold submerged in the fiber bed (application of Patent Number $4,861,354$ ) has the potential to decrease wall effects by keeping the inlet away from vertical side walls. ${ }^{(5)}$

Additional testing of larger acoustic drivers, properly coupled to the test module, is recommended to minimize the cleaning duration between cycles. Sonic horns with output of 150 to $160 \mathrm{db}$ in the 130 to $200 \mathrm{~Hz}$ range should be evaluated for coupling to the NFF to determine the feasibility of using current technology. Development of a larger pulse combustor is recommended for the NFF cleaning application. METC has developed design criteria for pulse combustor applications which could be evaluated for maximum acoustic intensity and coupled to the NFF design.

Extended testing over 6 to 12 months is recommended to demonstrate reliable operation of the NFF. Once reliable operation is achieved, the risk of scale-up to commercial application may be acceptable to industrial partners who would then participate in building prototype or demonstration size filters. 


\section{References}

(1) Richards, et al, "Thermal Pulse Combustion," paper presented at the Eighth Annual Heat Engines Contractors Meeting, Morgantown Energy Technology Center, July 1991.

(2) Rubow, L.N., et al, "Technical and Economic Evaluation of Ten High-Temperature, High-Pressure Particulate Cleanup Systems for Pressurized Fluidized Bed Combustion," Contract No. DE-AM21-82MC19196, DOE/MC/19196-1654, DE840012004 (July 1984).

(3) Bedick, R. D. and Dellefield, R. J., "Particulate Control at High-Temperature and HighPressure for Emerging Electric Power Generation Technologies," Proceedings of the Sixth Symposium on the Transfer and Utilization of Particulate Control Technology, EPRI CS-4918, Volume 1, Page 10-2, November 1986.

(4) Chemical Engineering, Economic Indicators, McGraw-Hill, Volume 100, No. 2, February 1993.

(5) U.S. Patent Number 4,861,354, "Removing Pollutant", Assignee: Battelle Memorial Institute, August 29, 1989. 
APPENDIX A

TEST DATA 


\section{Appendix A: Test Data}

Table A1. Test 8-8/91

\begin{tabular}{|c|c|c|c|}
\hline & $\underset{1}{\text { Cycle }}$ & $\begin{array}{c}\text { Cycle } \\
2\end{array}$ & $\begin{array}{c}\text { Cycle } \\
3\end{array}$ \\
\hline $\begin{array}{l}\text { NFF Basket (Basket) } \\
\text {-Top Temp F }\end{array}$ & 938 & 1007 & 1010 \\
\hline $\begin{array}{l}\text { NFF (Basket) } \\
\text {-Bottom Temp }\end{array}$ & 1144 & 1213 & 1235 \\
\hline $\begin{array}{l}\text { NFF dp - prior } \\
\text {-Cleaning ("water) }\end{array}$ & 7.5 & $10^{\prime \prime}$ & 12.2 \\
\hline $\begin{array}{l}\text { NFF Filtration } \\
\text {-Duration (min) }\end{array}$ & 137 & 57.25 & 56.25 \\
\hline $\begin{array}{l}\text { Reference NFF dp } \\
\text {-After cleaning ("water) }\end{array}$ & $2.1^{\prime \prime}$ & $2.1^{\prime \prime}$ & $2.3^{\prime \prime}$ \\
\hline Cleaning Duration & $5 \mathrm{~min}$ & $3 \mathrm{~min}$ & $3 \mathrm{~min}$ \\
\hline $\begin{array}{l}\text { Total Exhaust Flue Gas } \\
\text { (cfm) }\end{array}$ & 741 & 824 & 848 \\
\hline $\begin{array}{l}\text { Face Velocity } \\
(\mathrm{ft} / \mathrm{min})\end{array}$ & 124 & 137 & 141 \\
\hline FBC Flue Gas Temp & 1507 & 1577 & 1593 \\
\hline $\begin{array}{l}\text { FBC Bed (Comb) } \\
\text { ("water) }\end{array}$ & 25 & 27 & 22 \\
\hline $\begin{array}{l}\text { Comb Air } \\
(\mathrm{lb} / \mathrm{hr})\end{array}$ & 1086 & 1086 & 1086 \\
\hline $\begin{array}{l}\text { Coal Feed Rate } \\
\text { Limestone Feed Rate }\end{array}$ & & 65.5 & 99 \\
\hline
\end{tabular}




\section{NFF 8/8/91}

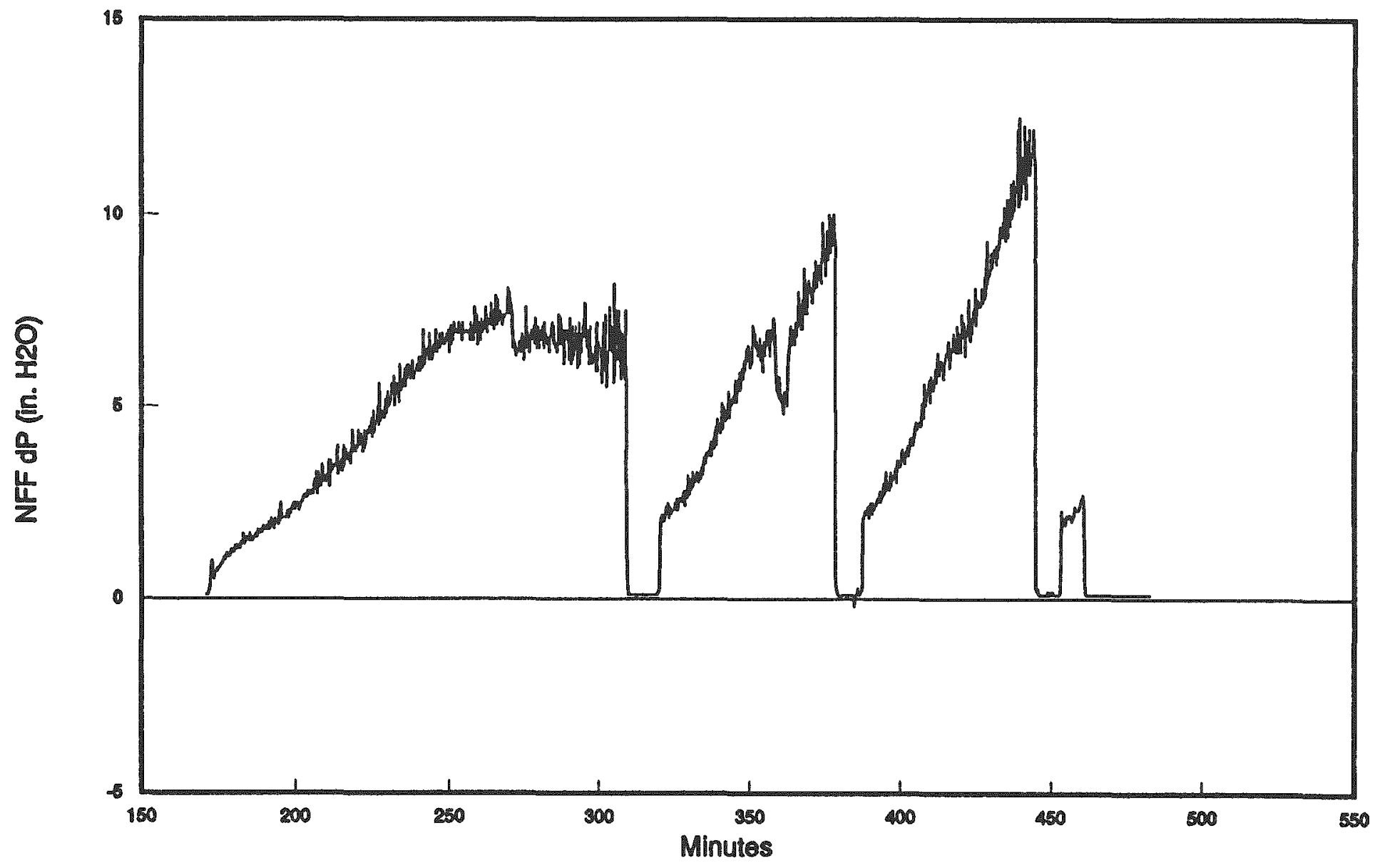

Figure A1. NFF 8/8/91 
Table A2. Test 8-14/91

\begin{tabular}{|c|c|c|c|c|c|}
\hline & $\begin{array}{c}\text { Cycle } \\
1\end{array}$ & $\begin{array}{c}\text { Cycle } \\
2 \\
\end{array}$ & $\begin{array}{c}\text { Cycle } \\
3\end{array}$ & $\begin{array}{c}\text { Cycle } \\
4\end{array}$ & $\begin{array}{c}\text { Cycle } \\
5\end{array}$ \\
\hline $\begin{array}{l}\text { NFF Basket (Basket) } \\
\text {-Top Temp F }\end{array}$ & 964 & 1075 & 1163 & 1149 & 1075 \\
\hline $\begin{array}{l}\text { NFF (Basket) } \\
\text {-Bottom Temp }\end{array}$ & 975 & 1119 & 1198 & 1202 & 1161 \\
\hline $\begin{array}{l}\text { NFF dp - prior } \\
\text {-Cleaning ("water) }\end{array}$ & 9.5 & $7.6^{\prime \prime}$ & $8^{\prime \prime}$ & 8.1 & $7.6^{\prime \prime}$ \\
\hline $\begin{array}{l}\text { NFF Filtration } \\
\text {-Duration (min) }\end{array}$ & 20 & 19 & 25 & 16 & 16 \\
\hline $\begin{array}{l}\text { Reference NFF dp } \\
\text {-After cleaning ("water) }\end{array}$ & $2.4^{\prime \prime}$ & $2.4^{\prime \prime}$ & $3.3^{\prime \prime}$ & $2.8^{\prime \prime}$ & $2.2^{\prime \prime}$ \\
\hline Cleaning Duration & $3 \mathrm{~min}$ & $3 \mathrm{~min}$ & N/A & N/A & N/A \\
\hline $\begin{array}{l}\text { Total Exhaust Flue Gas } \\
\text { (cfm) }\end{array}$ & 674 & 817 & 878 & 878 & 833 \\
\hline $\begin{array}{l}\text { Face Velocity } \\
\text { (ft/min) }\end{array}$ & 112 & 136 & 146 & 146 & 139 \\
\hline FBC Flue Gas Temp & 1529 & 1560 & 1588 & 1593 & 16293 \\
\hline $\begin{array}{l}\text { FBC Bed (Comb) } \\
\text { ("water) }\end{array}$ & 24 & 24 & 22 & 23 & 24 \\
\hline $\begin{array}{l}\text { Comb Air } \\
(\mathrm{lb} / \mathrm{hr})\end{array}$ & 1174 & 1174 & 1174 & 1174 & 1174 \\
\hline $\begin{array}{l}\text { Coal Feed Rate } \\
\text { Limestone Feed Rate }\end{array}$ & & 58 & 107.7 & & \\
\hline
\end{tabular}




\section{NFF 8/14/91}

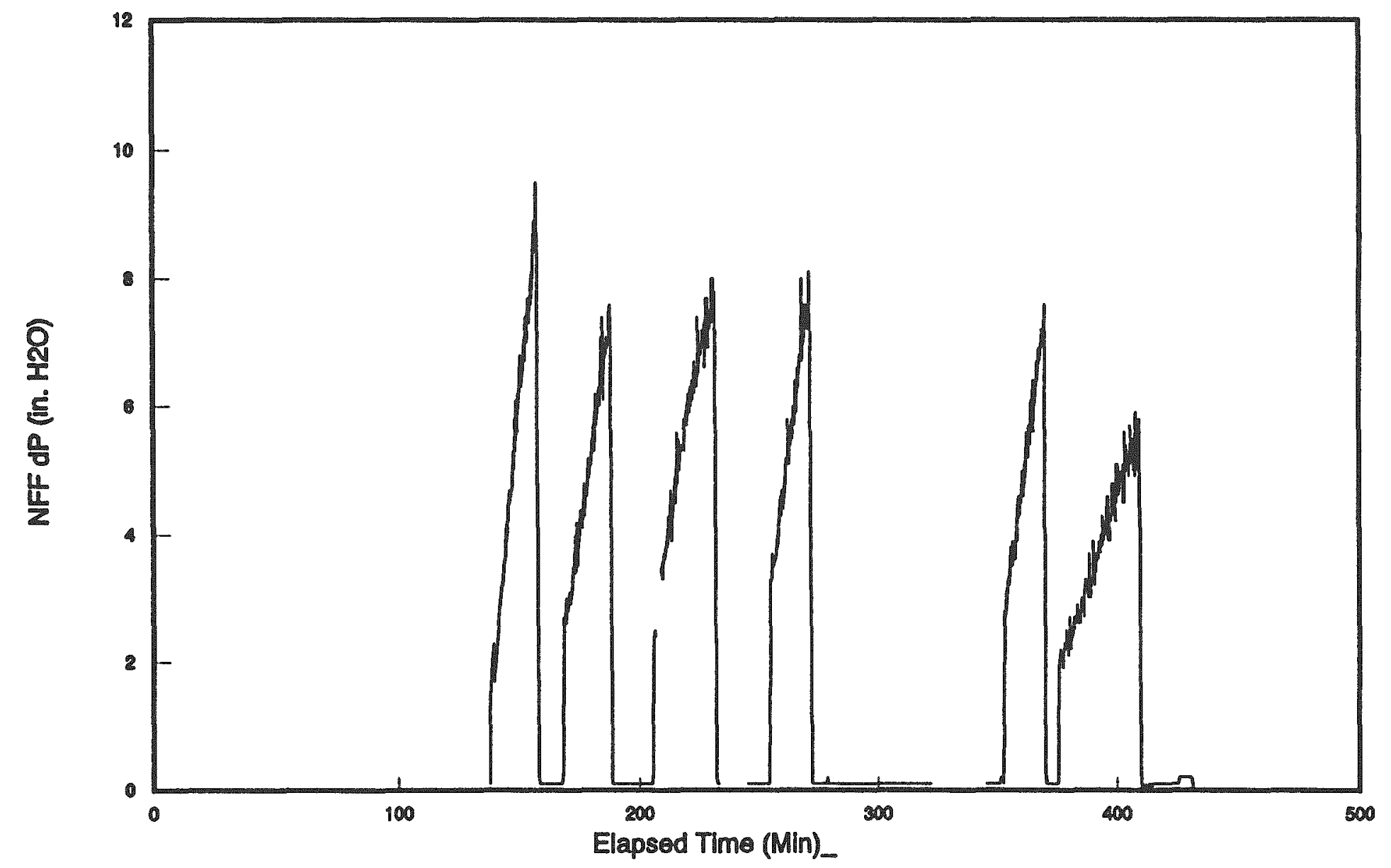

Figure A2. NFF 8/14/91 
Table A3. Test 8-16/91

\begin{tabular}{|c|c|c|c|c|}
\hline & $\underset{1}{\text { Cycle }}$ & $\begin{array}{c}\text { Cycle } \\
2\end{array}$ & $\begin{array}{c}\text { Cycle } \\
3\end{array}$ & $\begin{array}{c}\text { Cycle } \\
4\end{array}$ \\
\hline $\begin{array}{l}\text { NFF Basket (Basket) } \\
\text {-Top Temp F }\end{array}$ & 986 & 1026 & 1084 & 1084 \\
\hline $\begin{array}{l}\text { NFF (Basket) } \\
\text {-Bottom Temp }\end{array}$ & 1081 & 1143 & 1189 & 1201 \\
\hline $\begin{array}{l}\text { NFF dp - prior } \\
\text {-Cleaning ("water) }\end{array}$ & $7.1^{\prime \prime}$ & $7.2^{n}$ & $7.6^{\prime \prime}$ & $8.5^{\circ}$ \\
\hline $\begin{array}{l}\text { NFF Filtration } \\
\text {-Duration (min) }\end{array}$ & 21 & 19 & 13 & 7.75 \\
\hline $\begin{array}{l}\text { Reference NFF dp } \\
\text {-After cleaning ("water) }\end{array}$ & $2.8^{\prime \prime}$ & $3.6^{\prime \prime}$ & $4.3^{\prime \prime}$ & $5.7^{\prime \prime}$ \\
\hline Cleaning Duration & $3 \mathrm{~min}$ & $3 \mathrm{~min}$ & $3 \mathrm{~min}$ & N/A \\
\hline $\begin{array}{l}\text { Total Exhaust Flue Gas } \\
\text { (cfm) }\end{array}$ & 748 & 820 & 826 & 871 \\
\hline $\begin{array}{l}\text { Face Velocity } \\
(\mathrm{f} / \mathrm{min})\end{array}$ & 125 & 137 & 144 & 145 \\
\hline FBC Flue Gas Temp & 1590 & 1607 & 1623 & 1636 \\
\hline $\begin{array}{l}\text { FBC Bed (Comb) } \\
\text { ("water) }\end{array}$ & 23 & 23 & 24 & 23 \\
\hline $\begin{array}{l}\text { Comb Air } \\
(\mathrm{lb} / \mathrm{hr})\end{array}$ & 1138 & 1138 & 1138 & 1138 \\
\hline \multicolumn{2}{|l|}{$\begin{array}{l}\text { Coal Feed Rate } \\
\text { Limestone Feed Rate }\end{array}$} & \multicolumn{3}{|c|}{103} \\
\hline
\end{tabular}


NNF 8/16/91

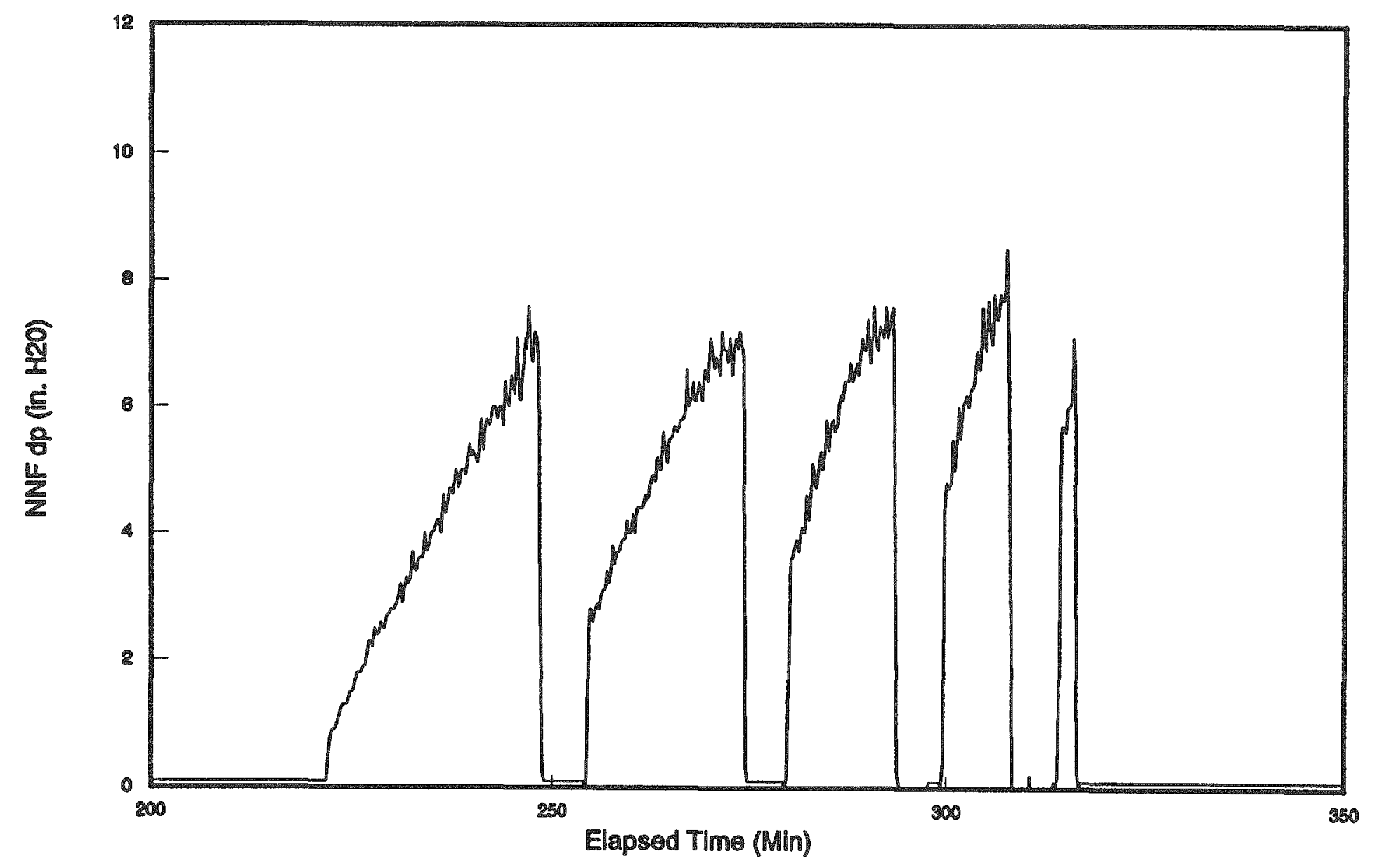

Figure A3. NFF 8/16/91 
Table A4. Test 8-19/91

\begin{tabular}{|l|c|c|c|c|}
\hline & $\begin{array}{c}\text { Cycle } \\
1\end{array}$ & $\begin{array}{c}\text { Cycle } \\
2\end{array}$ & $\begin{array}{c}\text { Cycle } \\
3\end{array}$ & $\begin{array}{c}\text { Cycle } \\
4\end{array}$ \\
\hline $\begin{array}{l}\text { NFF Basket (Basket) } \\
\text {-Top Temp F }\end{array}$ & 959 & 1007 & 1013 & 1033 \\
\hline $\begin{array}{l}\text { NFF (Basket) } \\
\text {-Bottom Temp }\end{array}$ & 1192 & 1243 & 1261 & 1259 \\
\hline $\begin{array}{l}\text { NFF dp - prior } \\
\text {-Cleaning ("water) }\end{array}$ & $10.9 "$ & $10.5 "$ & $10.8 "$ & $10.5^{\prime \prime}$ \\
\hline $\begin{array}{l}\text { NFF Filtration } \\
\text {-Duration (min) }\end{array}$ & 104 & 50 & 62 & 32 \\
\hline $\begin{array}{l}\text { Reference NFF dp } \\
\text {-After cleaning ("water) }\end{array}$ & $2.9^{\prime \prime}$ & $3.1^{\prime \prime}$ & $3.7 "$ & $3.4 "$ \\
\hline Cleaning Duration & $3 \mathrm{~min}$ & $3 \mathrm{~min}$ & $3 \mathrm{~min}$ & $3 \mathrm{~min}$ \\
\hline $\begin{array}{l}\text { Total Exhaust Flue Gas } \\
\text { (cfm) }\end{array}$ & 812 & 899 & 925 & 927 \\
\hline $\begin{array}{l}\text { Face Velocity } \\
\text { (ft/min) }\end{array}$ & 135 & 150 & 154 & 155 \\
\hline $\begin{array}{l}\text { FBC Flue Gas Temp } \\
\text { FBC Bed (Comb) }\end{array}$ & 1514 & 1579 & 1580 & 1591 \\
\hline $\begin{array}{l}\text { FB/hr < } \\
\text { ("water) }\end{array}$ & 24 & 24 & 25 \\
\hline $\begin{array}{l}\text { Comb Air } \\
\text { (lb/hr) }\end{array}$ & 1164 & 1164 & 1164 \\
\hline
\end{tabular}


Table A5. Test 8-20/91

\begin{tabular}{|c|c|c|c|c|c|}
\hline & $\begin{array}{c}\text { Cycle } \\
\mathbb{1}\end{array}$ & $\begin{array}{c}\text { Cycle } \\
2\end{array}$ & $\begin{array}{c}\text { Cycle } \\
3\end{array}$ & Cycle & $\begin{array}{c}\text { Cycle } \\
5\end{array}$ \\
\hline $\begin{array}{l}\text { NFF Basket (Basket) } \\
\text {-Top Temp F }\end{array}$ & 1034 & 990 & 1085 & 1125 & 1180 \\
\hline $\begin{array}{l}\text { NFF (Basket) } \\
\text {-Bottom Temp }\end{array}$ & 1099 & 1094 & 1183 & 1230 & 1267 \\
\hline $\begin{array}{l}\text { NFF dp - prior } \\
\text {-Cleaning ("water) }\end{array}$ & $6.3^{\prime \prime}$ & $6.8^{\prime \prime}$ & $6.2^{\prime \prime}$ & $6.8 "$ & $7.3^{\prime \prime}$ \\
\hline $\begin{array}{l}\text { NFF Filtration } \\
\text {-Duration (min) }\end{array}$ & 16.5 & 13.5 & 12.75 & 12.75 & 15.5 \\
\hline $\begin{array}{l}\text { Reference NFF dp } \\
\text {-After cleaning ("water) }\end{array}$ & $3.3^{\prime \prime}$ & $3.6^{\prime \prime}$ & $3.9^{\prime \prime}$ & $4.6^{\prime \prime}$ & $5.8^{\prime \prime}$ \\
\hline Cleaning Duration & $3 \mathrm{~min}$ & $3 \mathrm{~min}$ & $3 \mathrm{~min}$ & $3 \mathrm{~min}$ & $3 \mathrm{~min}$ \\
\hline $\begin{array}{l}\text { Total Exhaust Flue Gas } \\
\text { (cfm) }\end{array}$ & 818 & 811 & 896 & 932 & 963 \\
\hline $\begin{array}{l}\text { Face Velocity } \\
(\mathrm{ft} / \mathrm{min})\end{array}$ & 136 & 135 & 149 & 155 & 161 \\
\hline FBC Flue Gas Temp & 1630 & 1655 & 1661 & 1665 & 1669 \\
\hline $\begin{array}{l}\text { FBC Bed (Comb) } \\
\text { ("water) }\end{array}$ & 24 & 25 & 25 & 24 & 26 \\
\hline $\begin{array}{l}\text { Comb Air } \\
(\mathrm{lb} / \mathrm{hr})\end{array}$ & 1215 & 1215 & 1215 & 1215 & 1215 \\
\hline $\begin{array}{ll} & \text { Coal Feed Rate } \\
\mathrm{lb} / \mathrm{hr}< & \text { Limestone Feed Rate } \\
\end{array}$ & \multicolumn{5}{|c|}{109} \\
\hline
\end{tabular}




\section{NFF 8/20/91}

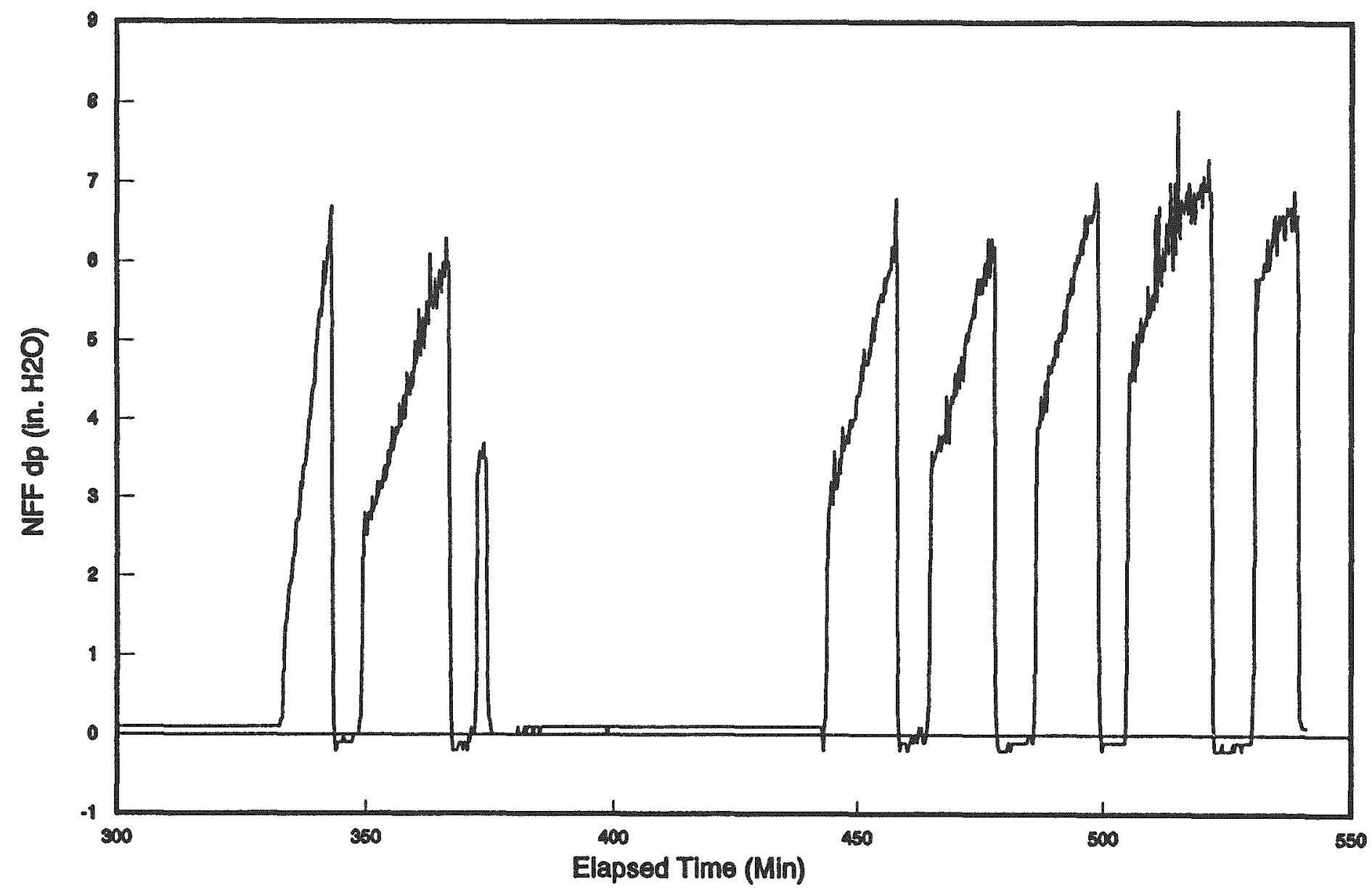

Figure A-4. NFF 8/20/91 
Table A6. Test 9-12/91

\begin{tabular}{|l|c|}
\hline & $\begin{array}{c}\text { Cycle } \\
1\end{array}$ \\
\hline $\begin{array}{l}\text { NFF Basket (Basket) } \\
\text {-Top Temp F }\end{array}$ & 1053 \\
\hline $\begin{array}{l}\text { NFF (Basket) } \\
\text {-Bottom Temp }\end{array}$ & 1021 \\
\hline $\begin{array}{l}\text { NFF dp - prior } \\
\text {-Cleaning ("water) }\end{array}$ & $7.9 "$ \\
\hline $\begin{array}{l}\text { NFF Filtration } \\
\text {-Duration (min) }\end{array}$ & 40 \\
\hline $\begin{array}{l}\text { Reference NFF dp } \\
\text {-After cleaning ("water) }\end{array}$ & $1.5 "$ \\
\hline Cleaning Duration & N/A \\
\hline $\begin{array}{l}\text { Total Exhaust Flue Gas } \\
\text { (cfm) }\end{array}$ & 598 \\
\hline $\begin{array}{l}\text { Face Velocity } \\
\text { (ft/min) }\end{array}$ & 100 \\
\hline FBC Flue Gas Temp & 1320 \\
\hline $\begin{array}{l}\text { FBC Bed (Comb) } \\
\text { ("water) }\end{array}$ & 22 \\
\hline $\begin{array}{l}\text { Comb Air } \\
\text { (lb/hr) }\end{array}$ & 10076 \\
\hline $\begin{array}{l}\text { Coal Feed Rate } \\
\text { Limestone Feed Rate }\end{array}$ & 132.7 \\
\hline
\end{tabular}


NFF 9/12/91

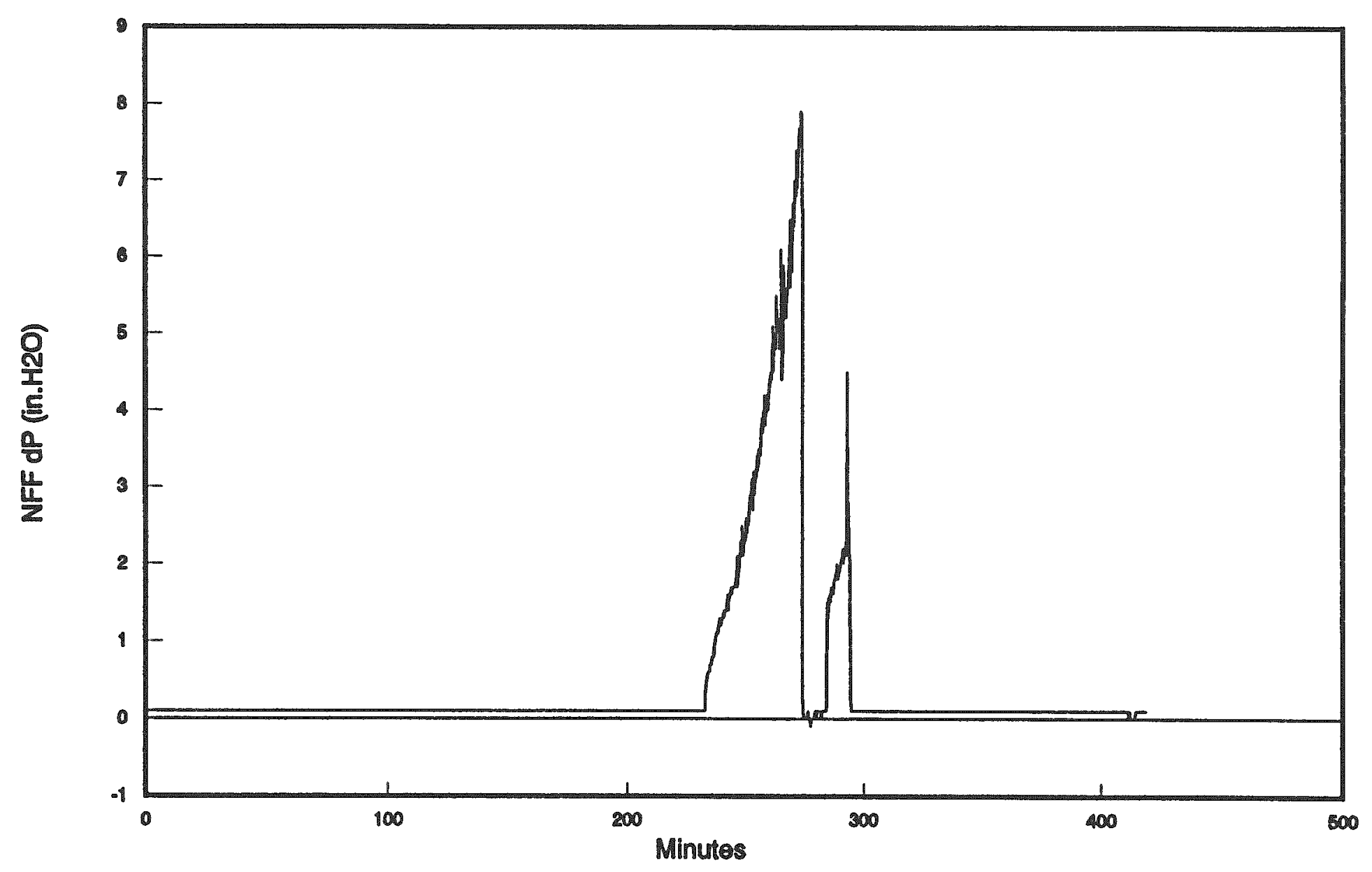

Figure A5. NFF 9/12/91 
Table A7. Fluidized Bed Run Conditions for Tests 11-1 through 11-4

\begin{tabular}{||c|c|c|c|c|c|c||}
\hline $\begin{array}{c}\text { Operating } \\
\text { Conditions }\end{array}$ & $\begin{array}{c}\text { Test } \\
11-1\end{array}$ & $\begin{array}{c}\text { Test } \\
11-2\end{array}$ & $\begin{array}{c}\text { Test } \\
11-3\end{array}$ & \multicolumn{3}{|c||}{ Test } \\
\hline $\begin{array}{c}\text { Combustion (160) } \\
\text { Flue Gas Temp F }\end{array}$ & 1166 & 1273 & 1292 & 1232 & 1312 & 1346 \\
\hline $\begin{array}{c}\text { FBC Bed Level } \\
\text { (" water) }\end{array}$ & 23.93 & 26.16 & 24.72 & 23.99 & 22.52 & 29.74 \\
\hline $\begin{array}{c}\text { Coal Feed Rate } \\
\text { (lbs/hr) }\end{array}$ & -40 & $\sim 40$ & $\sim 40$ & $\sim 40$ & $\sim 40$ & $\sim 40$ \\
\hline $\begin{array}{c}\text { Limestone Feed } \\
\text { Rate (lbs/hr) }\end{array}$ & 32 & 32 & 32 & $\sim 32$ & $\sim 32$ & $\sim 32$ \\
\hline $\begin{array}{c}\text { Combustion Air } \\
\text { ("water) }\end{array}$ & 2.17 & 2.42 & 2.79 & 2.96 & 3.02 & 2.98 \\
\hline
\end{tabular}


Table A8. NFF Performance Results for Tests $11-1$ through $11-4: 1{ }^{\prime} \times 1.5 ' \times 8^{\prime \prime}$ Bed

\begin{tabular}{|c|c|c|c|c|c|c|}
\hline $\begin{array}{l}\text { Operating } \\
\text { Conditions }\end{array}$ & $\begin{array}{l}\text { Test } \\
11-1\end{array}$ & $\begin{array}{l}\text { Test } \\
11-2\end{array}$ & $\begin{array}{l}\text { Test } \\
11-3\end{array}$ & \multicolumn{3}{|c|}{$\begin{array}{l}\text { Test } \\
11-4\end{array}$} \\
\hline $\begin{array}{l}\text { NFF Basket } \\
\text { - Top Temp F }\end{array}$ & 725 & 741 & 736 & 718 & 793 & 732 \\
\hline $\begin{array}{c}\text { NFF Basket } \\
\text { - Bottom Temp F }\end{array}$ & 735 & 757 & 745 & 736 & 810 & 782 \\
\hline $\begin{array}{l}\text { NFF dp - prior to } \\
\text { cleaning (" water) }\end{array}$ & 8.8 & 7.2 & 7.2 & 9.0 & 9.0 & 6.5 \\
\hline $\begin{array}{l}\text { NFF Filtration } \\
\text { Duration (min) }\end{array}$ & 225 & 347 & 170 & 174 & 155 & 77 \\
\hline $\begin{array}{c}\text { Reference NFF } \\
\text { dp } \\
\text { after cleaning } \\
\text { (" water) }\end{array}$ & $\begin{array}{l}\text { b.pulse - } \\
1.2 \\
\text { (backfire } \\
\text { mode) }\end{array}$ & $\begin{array}{c}\text { not } \\
\text { available } \\
\text { (bed seal } \\
\text { damaged) }\end{array}$ & $\begin{array}{c}\text { b.pulse - } \\
6.2 \\
\text { s.horn }-3.5 \\
\text { p.vibr }-2.4\end{array}$ & $\begin{array}{l}\text { t.pulse }-8.0 \\
\text { s.horn } 8 \\
\text { p.vibr }-3.5\end{array}$ & $\begin{array}{c}\text { s.horn \& } \\
\text { p.vibr - } 3.5\end{array}$ & $\begin{array}{c}\text { s.horn \& } \\
\text { p.vibr - } \\
2.7\end{array}$ \\
\hline $\begin{array}{c}\text { Cleaning } \\
\text { Duration } \\
\text { (min) }\end{array}$ & $\begin{array}{l}\text { b.pulse - } \\
\text { (backfire } \\
\text { mode) }\end{array}$ & $\begin{array}{c}\text { not } \\
\text { available } \\
\text { (bed seal } \\
\text { damaged) }\end{array}$ & $\begin{array}{l}\text { b.pulse - } \\
\text { s.horn - } \\
\text { p.vibr - }\end{array}$ & $\begin{array}{l}\text { t.pulse }-6 \\
\text { s.horn \& } \\
\text { p.vibr }-9\end{array}$ & $\begin{array}{c}\text { s.horn \& } \\
\text { p.vibr - } 10\end{array}$ & $\begin{array}{c}\text { s.horn \& } \\
\text { p.vibr - } \\
10\end{array}$ \\
\hline $\begin{array}{l}\text { Total Exhaust } \\
\text { Flue Gas - Calc. } \\
\text { (c.ft/min) }\end{array}$ & 269 & 269 & 289 & 297 & 300 & 298 \\
\hline $\begin{array}{l}\text { Face Velocity } \\
(\mathrm{ft} / \mathrm{min})\end{array}$ & 179 & 179 & 192 & 198 & 200 & 199 \\
\hline $\begin{array}{c}\text { Particulate } \\
\text { Loading (ppm) } \\
\text { - inlet (average) }\end{array}$ & $\mathrm{N} / \mathrm{A}$ & $\begin{array}{r}1500 \\
2000^{*} \\
\end{array}$ & $\begin{array}{l}3870 \\
2000^{*} \\
\end{array}$ & & $\begin{array}{l}5564 \\
2000^{*}\end{array}$ & \\
\hline $\begin{array}{l}\text { Particulate } \\
\text { Loading (ppm) } \\
\text { - Exhaust }\end{array}$ & N/A & 90 & 177 & & 611 & \\
\hline $\begin{array}{c}\text { Collection } \\
\text { Efficiency.\% } \\
\text { (for } 2000 \mathrm{ppm} \text { ) }\end{array}$ & N/A & 99.5 & 91.2 & & 69.5 & \\
\hline
\end{tabular}

* Average particulate loading. 


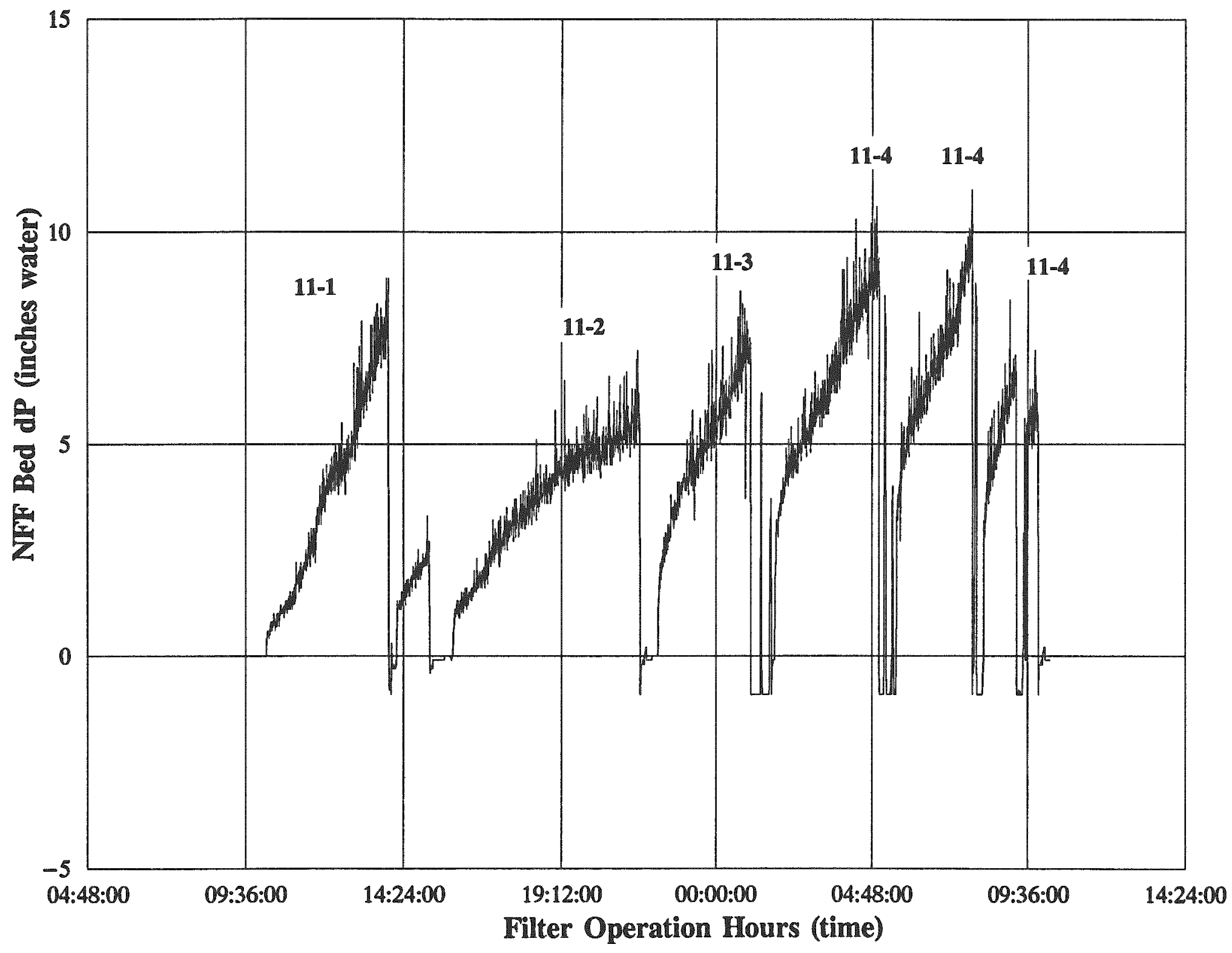

Figure A6. NFF Tests (11-1 to 11-4):1' $\times 1.5 \times 8^{\prime \prime}$ Bed 
Table A9. Fluidized Bed Run Conditions for Tests $12-1$ and $12-2$

\begin{tabular}{|c|c|c|c|c|c|c|c|}
\hline $\begin{array}{l}\text { Operating } \\
\text { Conditions }\end{array}$ & \multicolumn{3}{|c|}{$\begin{array}{l}\text { Test } \\
12-1\end{array}$} & \multicolumn{4}{|c|}{$\begin{array}{l}\text { Test } \\
12-2\end{array}$} \\
\hline $\begin{array}{c}\text { Combustion } \\
(160) \\
\text { Flue Gas Temp F }\end{array}$ & 1210 & 1256 & 1275 & 1246 & 1268 & 1292 & 1316 \\
\hline $\begin{array}{l}\text { FBC Bed Level } \\
\text { (" water) }\end{array}$ & 22.4 & 22.28 & 22.75 & 21.09 & 21.22 & 22.65 & 24.23 \\
\hline $\begin{array}{l}\text { Coal Feed Rate } \\
\text { (lbs/hr) }\end{array}$ & -40 & -40 & $\sim 40$ & $\sim 40$ & -40 & $\sim 40$ & -40 \\
\hline $\begin{array}{c}\text { Limestone Feed } \\
\text { Rate (lbs/hr) }\end{array}$ & 32 & 32 & 32 & 32 & 32 & 32 & 32 \\
\hline $\begin{array}{l}\text { Combustion Air } \\
\text { (" water) }\end{array}$ & 2.05 & 2.00 & 2.00 & 2.01 & 2.00 & 2.00 & 2.00 \\
\hline
\end{tabular}


Table A10. NFF Performance Results for Tests 12-1 and 12-2: $1^{9} \times 1.5^{\prime} \times 8^{\prime \prime}$ Modified Bed

\begin{tabular}{|c|c|c|c|c|c|c|c|}
\hline $\begin{array}{l}\text { Operating } \\
\text { Conditions }\end{array}$ & \multicolumn{3}{|c|}{$\begin{array}{l}\text { Test } \\
12-1 \\
\end{array}$} & \multicolumn{4}{|c|}{$\begin{array}{l}\text { Test } \\
12-2\end{array}$} \\
\hline $\begin{array}{l}\text { NFF Basket } \\
\text { - Top Temp F }\end{array}$ & 663 & 721 & 729 & 666 & 713 & 722 & 722 \\
\hline $\begin{array}{c}\text { NFF Basket } \\
\text { - Bottom Temp } F\end{array}$ & 667 & 716 & 719 & 661 & 706 & 713 & 722 \\
\hline $\begin{array}{c}\text { NFF dp - prior to } \\
\text { Cleaning } \\
\text { (" water) }\end{array}$ & 10.8 & 11.0 & 9.2 & 11.0 & 10.7 & 12.0 & 8.8 \\
\hline $\begin{array}{l}\text { NFF Filtration } \\
\text { Duration (min) }\end{array}$ & 181 & 120 & 95 & 108 & 99 & 85 & 60 \\
\hline $\begin{array}{l}\text { Reference NFF dp } \\
\text { after cleaning } \\
\text { (" water) }\end{array}$ & $\begin{array}{l}\text { s.horn - } \\
5.0 \\
\text { P.Vib - } \\
3.3\end{array}$ & $\begin{array}{c}\text { t.pulse - } \\
3.5 \\
\text { p.vib - } 3.0\end{array}$ & $\begin{array}{l}\text { t.pulse - } \\
6.5 \\
\text { p.vib - } \\
3.4\end{array}$ & $\begin{array}{c}\text { t.pulse - } \\
8.0 \\
\text { p.vib - } \\
4.3\end{array}$ & $\begin{array}{c}\text { t.pulse \& } \\
\text { s.horn - } \\
5.5 \\
\text { p.vib } \\
4.6 \\
\end{array}$ & $\begin{array}{c}\text { t.pulse \& } \\
\text { s.horn } \\
-6.0 \\
\text { p.vib } \\
5.0 \\
\end{array}$ & $\begin{array}{l}\text { p.vib- } \\
5.0\end{array}$ \\
\hline $\begin{array}{l}\text { Cleaning } \\
\text { Duration } \\
\text { (min) }\end{array}$ & $\begin{array}{l}\text { s.horn - } 10 \\
\text { P.Vib - } 3\end{array}$ & $\begin{array}{l}\text { t.pulse - } \\
10 \\
\text { p.vib - } 3\end{array}$ & $\begin{array}{c}\text { t.pulse - } \\
10 \\
\text { p.vib - } 2\end{array}$ & $\begin{array}{c}\text { t.pulse - } \\
10 \\
\text { p.vib } \\
-10\end{array}$ & $\begin{array}{l}\text { t.pulse }-10 \\
\text { s.horn - } 5 \\
\text { p.vib - } 5\end{array}$ & $\begin{array}{l}\text { t.pulse }-10 \\
\text { s.horn }-5 \\
\text { p.vib }-5\end{array}$ & $\begin{array}{l}\text { p.vib- } \\
10\end{array}$ \\
\hline $\begin{array}{c}\text { Total Exhaust } \\
\text { Flue Gas - Calc. } \\
\text { (c.ft/min) }\end{array}$ & 251 & 248 & 248 & 248 & 248 & 248 & 248 \\
\hline $\begin{array}{l}\text { Face Velocity } \\
(\mathrm{ft} / \mathrm{min})\end{array}$ & 201 & 198 & 198 & 199 & 198 & 198 & 198 \\
\hline $\begin{array}{l}\text { Loading (ppm) } \\
\text { - inlet }\end{array}$ & $2000^{*}$ & $2000^{*}$ & $2000^{*}$ & $2000^{\circ}$ & $2000^{*}$ & $2000^{\circ}$ & $2000^{*}$ \\
\hline $\begin{array}{l}\text { Loading (ppm) } \\
\text { - Exhaust }\end{array}$ & 24.0 & 18.2 & 12.2 & 7.2 & 6.1 & 6.3 & $\mathrm{n} / \mathrm{a}$ \\
\hline $\begin{array}{c}\text { Collection } \\
\text { Efficiency \% }\end{array}$ & 98.80 & 99.09 & 99.39 & 99.64 & 99.69 & 99.69 & \\
\hline
\end{tabular}

Note: All mechanical vibrator cleaning cycles in Test 12-2 was conducted with one vibrator.

* Average particulate loading. 


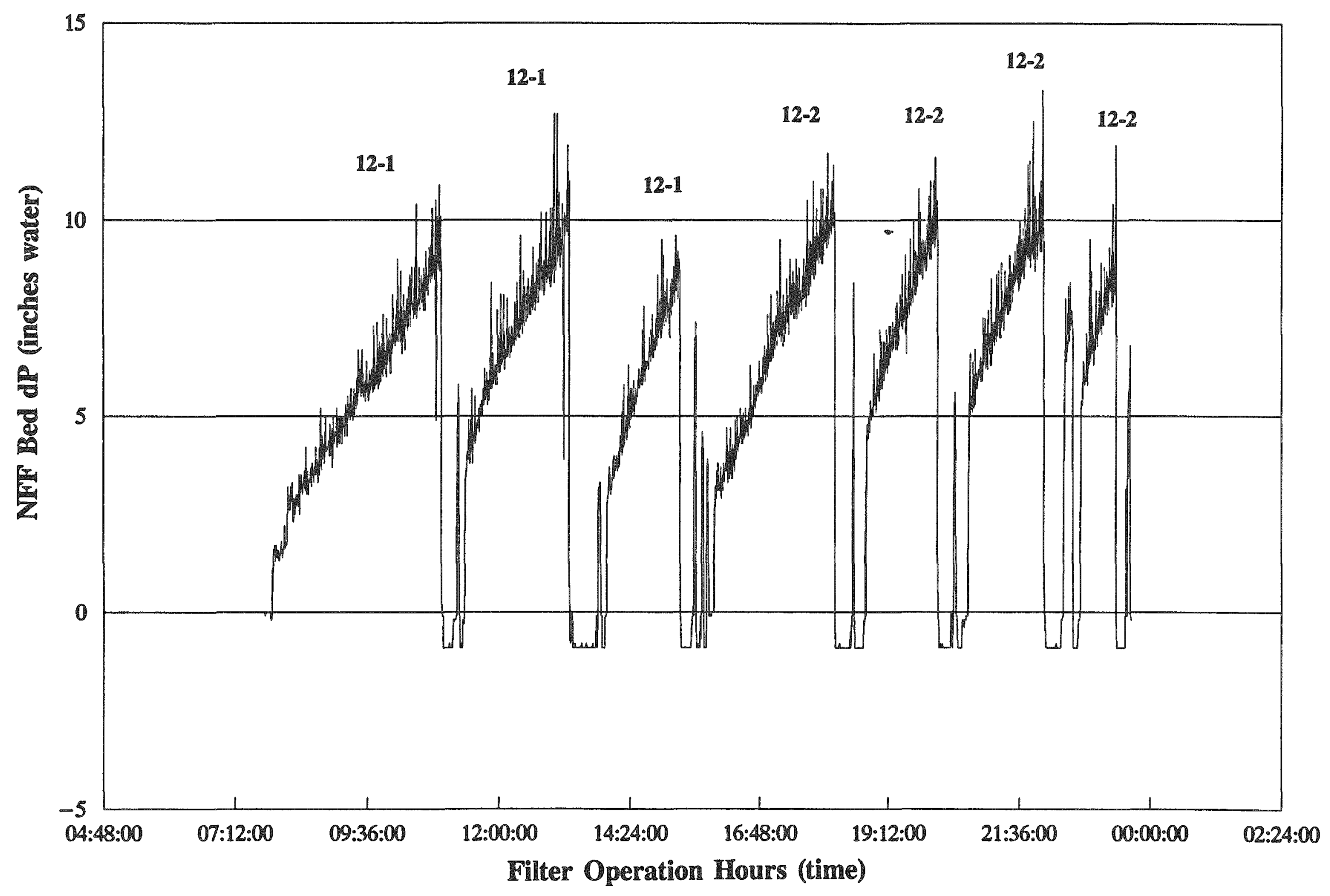

Figure A7. NFF Tests (12-1 to 12-2):1' \& $1.5^{\prime} \times 8^{\prime \prime}$ Bed 
Table A11. Fluidized Bed Run Conditions for Test 1-1

\begin{tabular}{|l|c|c|c|c|c|c||}
\hline \multicolumn{1}{|c|}{$\begin{array}{c}\text { Operating } \\
\text { Conditions }\end{array}$} & $\begin{array}{c}\text { Cycle } \\
1\end{array}$ & $\begin{array}{c}\text { Cycle } \\
2\end{array}$ & $\begin{array}{c}\text { Cycle } \\
\mathbf{3}\end{array}$ & $\begin{array}{c}\text { Cycle } \\
\mathbf{4}\end{array}$ & $\begin{array}{c}\text { Cycle } \\
\mathbf{5}\end{array}$ & $\begin{array}{c}\text { Cycle } \\
6\end{array}$ \\
\hline $\begin{array}{l}\text { Combustion (160) } \\
\text { Flue Gas Temp F }\end{array}$ & 1505 & 1577 & 1610 & 1643 & 1659 & 1663 \\
\hline $\begin{array}{l}\text { FBC Bed Level } \\
\text { ("water) }\end{array}$ & 23.9 & 24.6 & 25.8 & 26.5 & 24.8 & 27.2 \\
\hline $\begin{array}{l}\text { Coal Feed Rate } \\
\text { (lbs/hr) }\end{array}$ & $\sim 100$ & $\sim 100$ & $\sim 100$ & $\sim 100$ & $\sim 100$ & $\sim 100$ \\
\hline $\begin{array}{l}\text { Limestone Feed Rate } \\
\text { (lbs/hr) }\end{array}$ & $\sim 50$ & $\sim 50$ & -50 & $\sim 50$ & $\sim 50$ & $\sim 50$ \\
\hline $\begin{array}{l}\text { Combustion Air } \\
\text { (lb/hr) }\end{array}$ & 1264 & 1272 & 1272 & 1268 & 1264 & 1256 \\
\hline
\end{tabular}


Table A12. NFF Performance Results for Test 1-1: $4^{\prime} \times 1.5^{\prime} \mathrm{xy}^{\text {n }}$

\begin{tabular}{|c|c|c|c|c|c|c|}
\hline $\begin{array}{l}\text { Operating } \\
\text { Conditions }\end{array}$ & $\begin{array}{c}\text { Cycle } \\
1\end{array}$ & $\begin{array}{c}\text { Cycle } \\
2\end{array}$ & $\begin{array}{c}\text { Cycle } \\
3\end{array}$ & $\begin{array}{c}\text { Cycle } \\
4\end{array}$ & $\begin{array}{c}\text { Cycle } \\
5\end{array}$ & $\begin{array}{c}\text { Cycle } \\
6\end{array}$ \\
\hline $\begin{array}{l}\text { NFF Basket } \\
\text {-Top Temp F }\end{array}$ & 816 & 1035 & 1091 & 1061 & 1048 & 1059 \\
\hline $\begin{array}{l}\text { NFF Basket } \\
\text {-Bottom Temp F }\end{array}$ & 987 & 1140 & 1171 & 1174 & 1174 & 1183 \\
\hline $\begin{array}{l}\text { NFF dp - prior to } \\
\text { cleaning ("water) }\end{array}$ & 10.5 & 11.2 & 10.7 & 10.9 & 10.3 & 10.5 \\
\hline $\begin{array}{l}\text { NFF Filtration } \\
\text { Duration (min) }\end{array}$ & 43 & 30 & 23 & 20 & 23 & 27 \\
\hline $\begin{array}{l}\text { Reference NFF dp } \\
\text { after cleaning } \\
\text { ("water) }\end{array}$ & 3.3 & 4.3 & 3.8 & 4.2 & 3.5 & N/A \\
\hline $\begin{array}{l}\text { Cleaning Duration } \\
\text { (min) }\end{array}$ & 20 & 20 & 25 & 25 & $25 \mathrm{~min}$ & $15 \mathrm{~min}$ \\
\hline $\begin{array}{l}\text { Total Exhaust } \\
\text { Flue Gas - Calc. } \\
\text { (c ft/min) }\end{array}$ & 993 & 998 & 998 & 996 & 993 & 987 \\
\hline $\begin{array}{l}\text { Face Velocity } \\
\text { (ft/min) }\end{array}$ & 199 & 200 & 200 & 199 & 199 & 197 \\
\hline $\begin{array}{l}\text { Particulate } \\
\text { Loading (ppm) } \\
\text {-inlet (average) }\end{array}$ & & 782 & & & & \\
\hline $\begin{array}{l}\text { Particulate } \\
\text { Loading (ppm)- } \\
\text { Exhaust (average) }\end{array}$ & \multicolumn{3}{|c|}{44} & \multicolumn{3}{|c|}{$\begin{array}{l}\text { Possible Sampling Error: Leakage } \\
\text { detected in sample probe towards } \\
\text { the end of sampling. }\end{array}$} \\
\hline $\begin{array}{l}\text { Collection } \\
\text { Efficiency, \% }\end{array}$ & & 94.4 & & & & \\
\hline
\end{tabular}




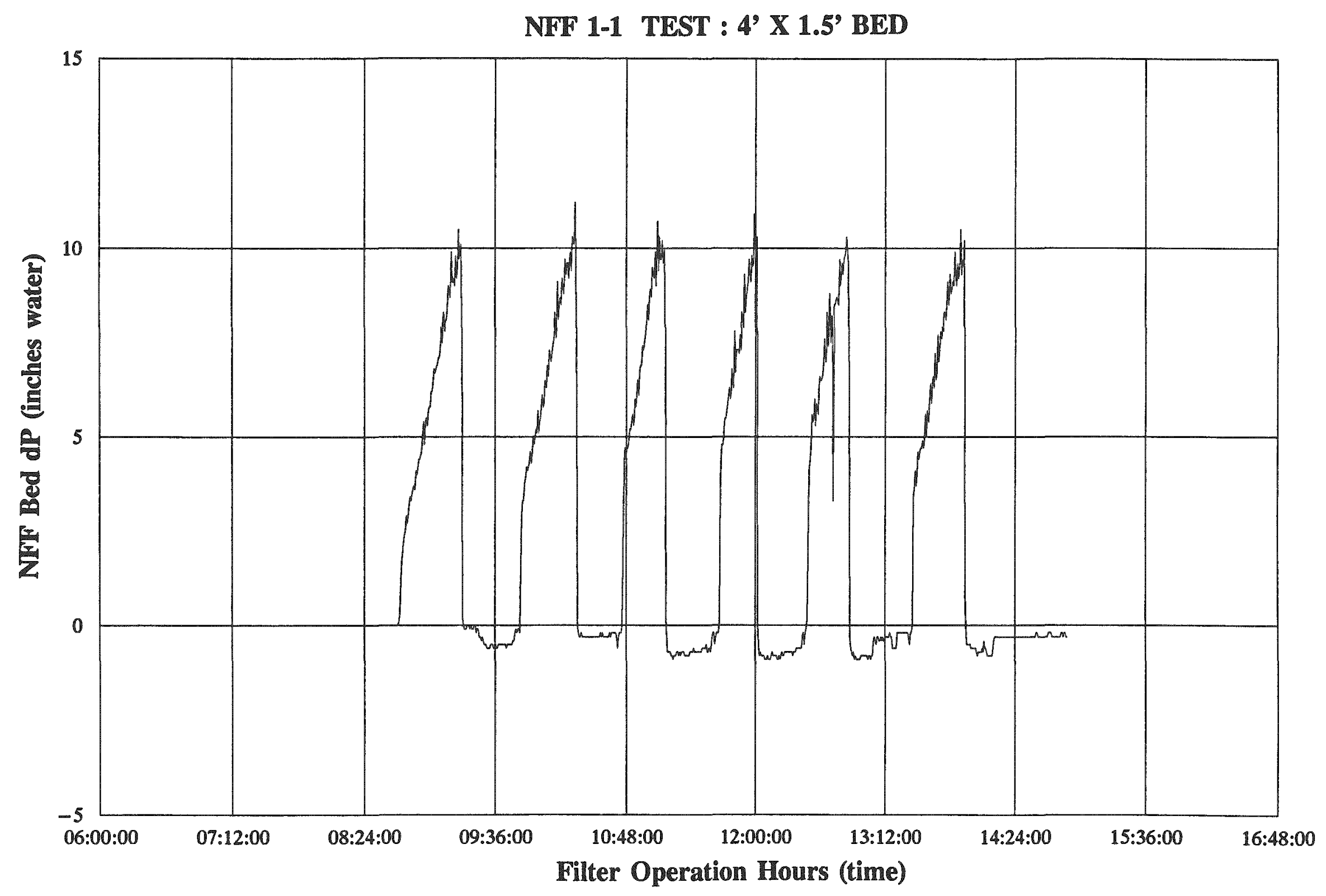

Figure A8. dp Profilles During Test 1-1, With 4' x 1.5' x 12" NFF Basket 
Table A13. Fluidized Bed Run Conditions for Test $1-2$

\begin{tabular}{|l|c|c|c|c|c|c|c|c|}
\hline \multicolumn{1}{|c|}{$\begin{array}{c}\text { Operating } \\
\text { Conditions }\end{array}$} & $\begin{array}{c}\text { Cycle } \\
\mathbf{1}\end{array}$ & $\begin{array}{c}\text { Cycle } \\
\mathbf{2}\end{array}$ & $\begin{array}{c}\text { Cycle } \\
\mathbf{3}\end{array}$ & $\begin{array}{c}\text { Cycle } \\
\mathbf{4}\end{array}$ & $\begin{array}{c}\text { Cycle } \\
\mathbf{5}\end{array}$ & $\begin{array}{c}\text { Cycle } \\
6\end{array}$ & $\begin{array}{c}\text { Cycle } \\
\mathbf{7}\end{array}$ & $\begin{array}{c}\text { Cycle } \\
8\end{array}$ \\
\hline $\begin{array}{l}\text { Combustion (160) } \\
\text { Flue Gas Temp F }\end{array}$ & 1567 & 1610 & 1634 & 1645 & 1672 & 1687 & 1697 & 1703 \\
\hline $\begin{array}{l}\text { FBC Bed Level } \\
\text { ("water) }\end{array}$ & 22.9 & 24.2 & 24.7 & 25.3 & 27.8 & 28.9 & 27.3 & 28.0 \\
\hline $\begin{array}{l}\text { Coal Feed Rate } \\
\text { (lbs/hr) }\end{array}$ & $\begin{array}{c}\sim 10 \\
0\end{array}$ & $\begin{array}{c}\sim 10 \\
0\end{array}$ & $\begin{array}{c}\sim 10 \\
0\end{array}$ & $\begin{array}{c}\sim 10 \\
0\end{array}$ & $\begin{array}{c}\sim 10 \\
0\end{array}$ & $\sim 100$ & $\begin{array}{c}\sim 10 \\
0\end{array}$ & $\sim 100$ \\
\hline $\begin{array}{l}\text { Limestone Feed Rate } \\
\text { (lbs/hr) }\end{array}$ & $\sim 50$ & $\sim 50$ & $\sim 50$ & $\sim 50$ & $\sim 50$ & $\sim 50$ & $\sim 50$ & $\sim 50$ \\
\hline $\begin{array}{l}\text { Combustion Air } \\
\text { (b/hr) }\end{array}$ & 1268 & 1260 & 1256 & 1244 & 1236 & 1244 & 1232 & 1264 \\
\hline
\end{tabular}


Table A14. NFF Performance Results for Test 1-2: 1' x 1.5' x 8" Bed

\begin{tabular}{|c|c|c|c|c|c|c|c|c|}
\hline $\begin{array}{l}\text { Operating } \\
\text { Conditions }\end{array}$ & $\begin{array}{c}\text { Cycle } \\
1\end{array}$ & $\begin{array}{l}\text { Cycle } \\
2\end{array}$ & $\begin{array}{c}\text { Cycle } \\
3\end{array}$ & $\begin{array}{c}\text { Cycle } \\
4\end{array}$ & $\begin{array}{c}\text { Cycle } \\
5\end{array}$ & $\begin{array}{c}\text { Cycle } \\
6\end{array}$ & $\begin{array}{c}\text { Cycle } \\
7\end{array}$ & $\begin{array}{c}\text { Cycle } \\
8\end{array}$ \\
\hline $\begin{array}{l}\text { NFF Basket } \\
\text {-Top Temp F }\end{array}$ & 848 & 1029 & 1045 & 1060 & 1048 & 1068 & 1054 & 1028 \\
\hline $\begin{array}{l}\text { NFF Basket } \\
\text {-Bottom Temp F }\end{array}$ & 1064 & 1156 & 1166 & 1187 & 1138 & 1202 & 1195 & 1192 \\
\hline $\begin{array}{l}\text { NFF dp - prior to } \\
\text { cleaning ("water) }\end{array}$ & 10.6 & 10.4 & 10.5 & 11.9 & 12.2 & 12.5 & 12.0 & 12.7 \\
\hline $\begin{array}{l}\text { NFF Filtration } \\
\text { Duration (min) }\end{array}$ & 45 & 17 & 18 & 21 & 23 & 20 & 14 & 13 \\
\hline $\begin{array}{l}\text { Reference NFF dp } \\
\text { after cleaning } \\
\text { ("water) }\end{array}$ & 5.4 & 5.7 & 5.8 & 4.7 & 6.2 & 6.5 & 6.6 & N/A \\
\hline $\begin{array}{l}\text { Cleaning Duration } \\
\text { (min) }\end{array}$ & 10 & 15 & 15 & 15 & 10 & 10 & 15 & 15 \\
\hline $\begin{array}{l}\text { Total Exhaust } \\
\text { Flue Gas - Calc. } \\
\text { (c ft/min) }\end{array}$ & 996 & 990 & 987 & 979 & 973 & 979 & 970 & 993 \\
\hline $\begin{array}{l}\text { Face Velocity } \\
(\mathrm{ft} / \mathrm{min})\end{array}$ & 199 & 198 & 197 & 196 & 195 & 196 & 194 & 199 \\
\hline $\begin{array}{l}\text { Loading (ppm) } \\
\text {-inlet (average) }\end{array}$ & & & & & & 1379 & & \\
\hline $\begin{array}{l}\text { Loading (ppm)- } \\
\text { Exhaust (average) }\end{array}$ & & & & & & 205 & & \\
\hline $\begin{array}{l}\text { Collection } \\
\text { Efficiency, \% }\end{array}$ & & & & & & 85.1 & & \\
\hline
\end{tabular}


NFF 1-2 Test : $4^{\prime} \times 1.5^{\prime}$ Bed

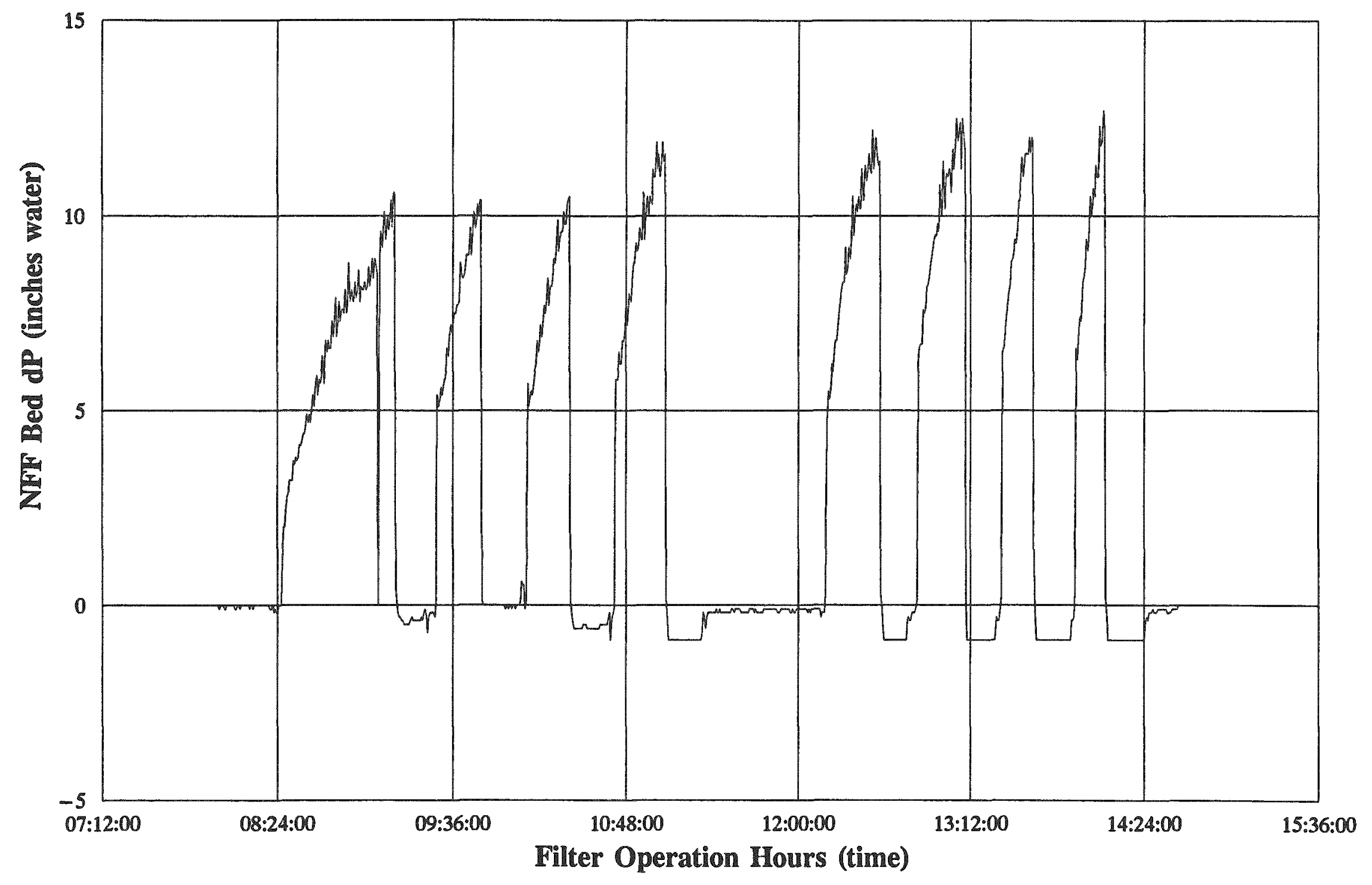

Figure A9. dp Profile During Test 1-2 with $4^{\prime} \times 1.5^{\prime} \times 12^{\prime \prime}$ Basket 
Table A15. Fluidized Bed Run Conditions for Test 2-1

\begin{tabular}{|c|c|c|c|c|c|c|c|c|}
\hline $\begin{array}{l}\text { Operating } \\
\text { Conditions }\end{array}$ & $\begin{array}{c}\text { Cycle } \\
1\end{array}$ & $\begin{array}{c}\text { Cycle }^{(a)} \\
2 \\
\end{array}$ & $\begin{array}{c}\text { Cycle }^{(a)} \\
3 \\
\end{array}$ & Cycle $^{(\mathrm{a})}$ & $\begin{array}{c}\text { Cycle }^{(a)} \\
5\end{array}$ & $\begin{array}{c}\text { Cycle }^{(\mathrm{a})} \\
6\end{array}$ & $\begin{array}{c}\text { Cycle }^{(a)} \\
7\end{array}$ & $\begin{array}{c}\text { Cycle }^{(a)} \\
8\end{array}$ \\
\hline $\begin{array}{l}\text { Combustion (160 F) } \\
\text { Flue Gas Temp F }\end{array}$ & 1495 & 1569 & 1589 & 1568 & 1581 & 1630 & 1672 & 1584 \\
\hline $\begin{array}{l}\text { FBC Bed Level } \\
\text { ("water") }\end{array}$ & 22.1 & 24.0 & 25.5 & 23.3 & 25.5 & 26.5 & 25.2 & $\mathbf{N} / \mathbf{A}$ \\
\hline $\begin{array}{l}\text { Coal Feed Rate } \\
(\mathrm{lbs} / \mathrm{hr})\end{array}$ & $\sim 100$ & $\sim 100$ & $\sim 100$ & $\sim 100$ & -100 & $\sim 100$ & -100 & -100 \\
\hline $\begin{array}{l}\text { Limestone Feed Rate } \\
\text { (lbs/hr) }\end{array}$ & $\sim 50$ & -50 & -50 & -50 & $\sim 50$ & -50 & $\sim 50$ & $\sim 50$ \\
\hline $\begin{array}{l}\text { Combustion Air } \\
(\mathrm{lb} / \mathrm{hr})\end{array}$ & 1248 & 1248 & 1244 & 1216 & 1240 & 1260 & 1252 & 1256 \\
\hline
\end{tabular}

(a) Fluid bed operating pressure was maintained at 1.0 to 1.5 psi. 
Table A16. NFF Performance Results for Test 2-1: $1^{\prime} \times 1.5^{\prime} \times 8^{\prime \prime}$ Bed

\begin{tabular}{|c|c|c|c|c|c|c|c|c|}
\hline $\begin{array}{l}\text { Operating } \\
\text { Conditions }\end{array}$ & $\begin{array}{c}\text { Cycle } \\
1\end{array}$ & $\begin{array}{c}\text { Cycle } \\
2\end{array}$ & $\begin{array}{c}\text { Cycle } \\
\mathbf{3}\end{array}$ & $\begin{array}{c}\text { Cycle } \\
4\end{array}$ & $\begin{array}{c}\text { Cycle } \\
5\end{array}$ & $\begin{array}{c}\text { Cycle } \\
6\end{array}$ & $\begin{array}{c}\text { Cycle } \\
7\end{array}$ & $\begin{array}{c}\text { Cycle } \\
8\end{array}$ \\
\hline NFF Basket -Top Temp F & 1017 & 1165 & 1179 & 1131 & 1097 & 1156 & 1109 & 1093 \\
\hline NFF Basket -Bottom Temp F & 1067 & 1178 & 1185 & 1136 & 1127 & 1181 & 1151 & 1122 \\
\hline $\begin{array}{l}\text { NFF dp - prior to } \\
\text { cleaning ("water") }\end{array}$ & 10.0 & 10.5 & 11.0 & 11.1 & 10.7 & 10.3 & 10.3 & 11.6 \\
\hline NFF Filtration Duration (min) & $74^{(a)}$ & 44 & 31 & 13 & 46 & 31 & 33 & N/A \\
\hline $\begin{array}{l}\text { Reference NFF dp after cleaning } \\
\text { ("water") }\end{array}$ & 2.4 & 4.5 & 4.2 & 2.4 & 3.3 & 3.2 & 3.7 & N/A \\
\hline Cleaning Duration (min) & 10 & $10^{(b)}$ & $15^{(b)}$ & $20^{(b)}$ & 15 & 15 & 15 & N/A \\
\hline $\begin{array}{l}\text { Total Exhaust Flue Gas } \\
\text { Calc. (c ft/min) }\end{array}$ & 982 & 982 & 979 & 958 & 979 & 990 & 972 & 979 \\
\hline Face Velocity (ft/min) & 197 & 197 & 196 & 188 & 196 & 198 & 195 & 197 \\
\hline Loading (ppm) - inlet (average) & \multicolumn{3}{|c|}{$1500^{(d)}$} & \multicolumn{3}{|c|}{$1500^{(d)}$} & \multicolumn{2}{|c|}{$1500^{(d)}$} \\
\hline Loading (ppm) - Exhaust (average) & \multicolumn{3}{|c|}{56} & \multicolumn{3}{|c|}{22} & \multicolumn{2}{|c|}{168} \\
\hline Collection Efficiency, \% & \multicolumn{3}{|c|}{96.3} & \multicolumn{3}{|c|}{98.5} & \multicolumn{2}{|c|}{88.8} \\
\hline
\end{tabular}
(a) Fresh bed.
(b) Only one mechanical vibrator was functional.
(c) Test suspended after this cycle due to fluid bed operational problem.
(d) Estimated inlet loading. 


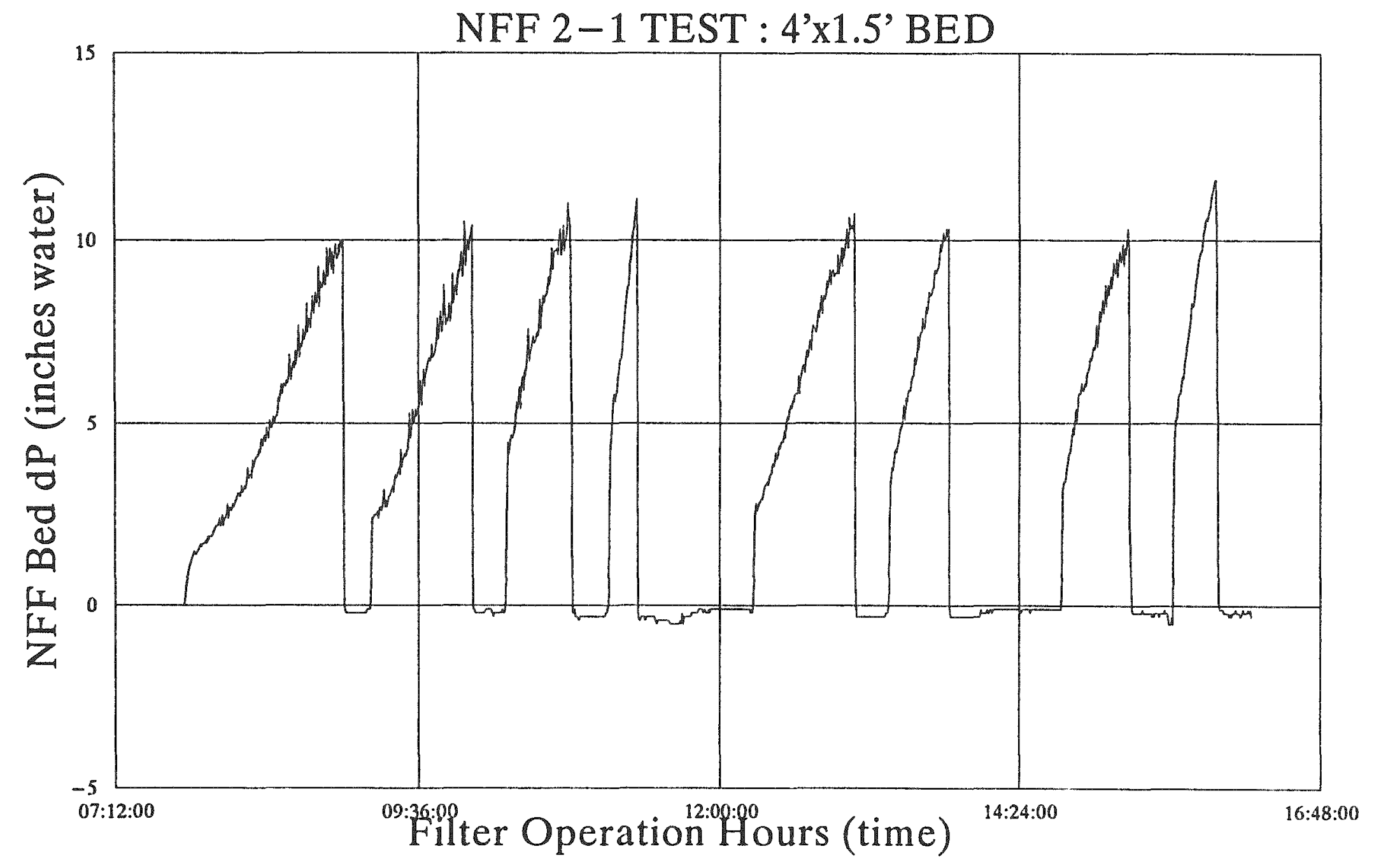

Figure A10. dp Measurements Across NFF Basket for Test 2-1 
Table A17. Coal Analysis

\begin{tabular}{|c|c|c|c|}
\hline & \multicolumn{2}{|c|}{ Proximate Analysis } & \\
\hline & As Received & Dry Basis & \\
\hline \% Moisture & 5.29 & xxxx & \\
\hline$\%$ Ash & 13.82 & 14.59 & \\
\hline$\%$ Volatile & 38.76 & 40.92 & \\
\hline \% Fixed Carbon & 42.13 & 44.49 & \\
\hline \multicolumn{3}{|c|}{100.00} & \\
\hline Btu/lb & 11382 & 12018 & \multirow[t]{2}{*}{ MAF 14071} \\
\hline \% Sulfur & 4.78 & 5.05 & \\
\hline
\end{tabular}


This cover stock is $30 \%$ post-consumer waste and $30 \%$ pre-consumer waste, and is recyclable. 
